\section{LA-8254-MS}

Informal Report
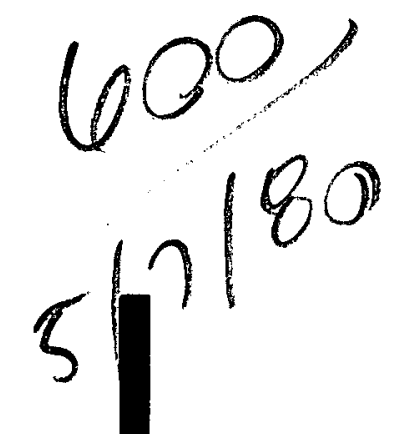

\section{MASTER}

Geophysical Well Logging Operations and

Log Analysis in Geothermal Well

Desert Peak No. B-23-1 


\section{DISCLAIMER}

This report was prepared as an account of work sponsored by an agency of the United States Government. Neither the United States Government nor any agency Thereof, nor any of their employees, makes any warranty, express or implied, or assumes any legal liability or responsibility for the accuracy, completeness, or usefulness of any information, apparatus, product, or process disclosed, or represents that its use would not infringe privately owned rights. Reference herein to any specific commercial product, process, or service by trade name, trademark, manufacturer, or otherwise does not necessarily constitute or imply its endorsement, recommendation, or favoring by the United States Government or any agency thereof. The views and opinions of authors expressed herein do not necessarily state or reflect those of the United States Government or any agency thereof. 


\section{DISCLAIMER}

Portions of this document may be illegible in electronic image products. Images are produced from the best available original document. 
This work was supported by the US Department of Energy, Division of Geothermal Energy.

This report was prepared as an account of work sponsored by the United States Government. Neither the United States nor the United States Department of Energy, nor uny of their employees, nor any of their contractors, subcontractors, or their employees, makes any warranty. express or implied, or assumes any legal liability or responsibility for the accuracy. completeness, or usefulness or any information, apparalus,

not infringe privately owned rights.

UNITED STATES DEPARTMENT OF ENERGY CONTRACT W-7408-ENG. 3 
LA-8254-MS

Informal Report

UC-66b

Issued: March 1980

\title{
Geophysical Well Logging Operations and \\ Log Analysis in Geothermal Well \\ Desert Peak No. B-23-1
}

\author{
Prepared for \\ Los Alamos Scientific Laboratory
}

by

Darshan K. Sethi*

Walter H. Fertl*

*Dresser Atlas, Dresser Industries, Inc., Houston, TX 77001.

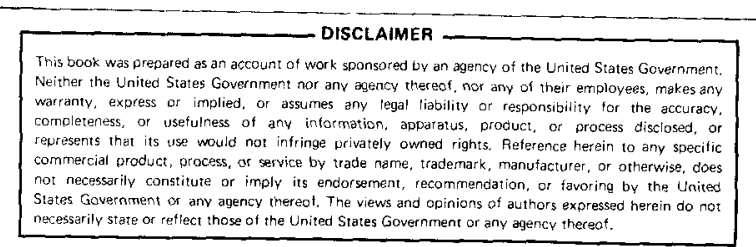

Under Contract L28-1926E

August 1979

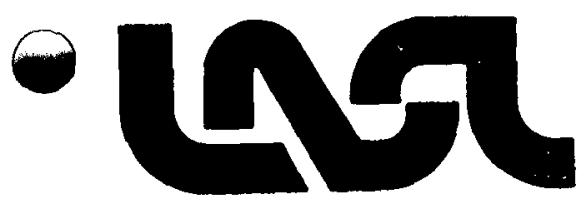




\section{CONTENTS}

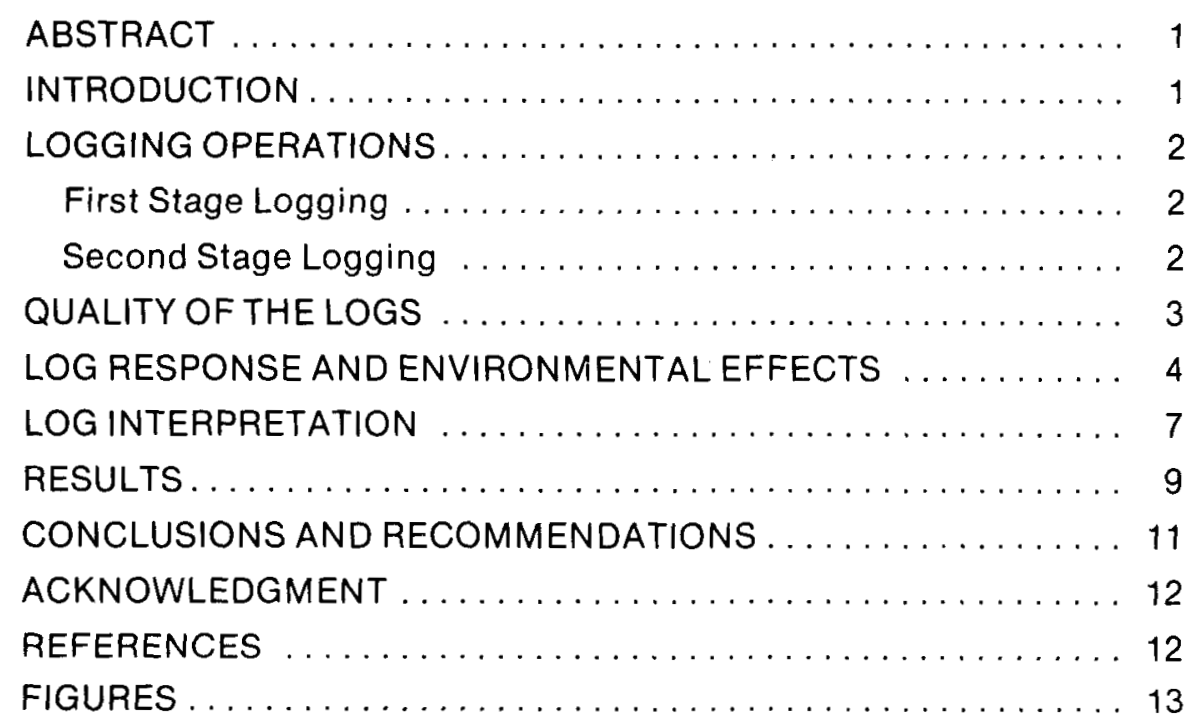

\section{APPENDIXES}

Lithologic $\log \ldots \ldots \ldots \ldots \ldots \ldots \ldots \ldots \ldots$ A -1

Logging Services for Geothermal Wells........ A - II

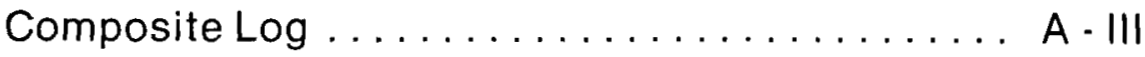

Induction Electrolog ${ }^{\circledR} \ldots \ldots \ldots \ldots \ldots \ldots \ldots$ A - IV

Spectralog Replot.................. A.V

Spectralog Ratio Plot ................ A - VI 


\title{
GEOPHYSICAL WELL LOGGING OPERATIONS \\ AND LOG ANALYSIS IN GEOTHERMAL WELL \\ DESERT PEAK NO. B-23-1
}

\author{
by \\ Darshan K. Sethi \\ Walter H. Fertl
}

\begin{abstract}
Geothermal Well Desert Peak No. B-23-1 was logged by Dresser Atlas during April/May 1979 to a total depth of $2939 \mathrm{~m}$ (9642 ft). A temperature of $209^{\circ} \mathrm{C}\left(408^{\circ} \mathrm{F}\right)$ was observed on the maximum thermometer run with one of the logging tools. Borehole tools rated to a maximum temperature of $204.4^{\circ} \mathrm{C}\left(400^{\circ} \mathrm{F}\right)$ were utilized for logging except for the Densilog ${ }^{\circledR}$ tool, which was from the other set of borehole instruments, rated to a still higher temperature, i.e., $260^{\circ} \mathrm{C}\left(500^{\circ} \mathrm{F}\right)$.

The quality of the logs recorded and the environmental effects on the log response have been considered. The log response in the unusual lithologies of igneous and metamorphic formations encountered in this well could be correlated with the drill cutting data.

An empirical, statistical log interpretation approach has made it possible to obtain meaningful information on the rocks penetrated. Various crossplots/histograms of the corrected log data have been generated on the computer. These are found to provide good resolution between the lithological units in the rock sequence. The crossplotting techniques and the statistical approach were combined with the drill cutting descriptions in order to arrive at the lithological characteristics. The results of log analysis and recommendations for logging of future wells have been included.
\end{abstract}

\section{INTRODUCTION}

In the northern Hot Springs Mountains of west Churchill County, Nevada, Desert Peak Geothermal Well No. B-23-1 terminates in granite at a depth of $2939 \mathrm{~m}$ (9642 ft) (see Figure 1). Geophysical well logging was performed here by Dresser Atlas in two stages. On April $5-6,1979$, the well was logged to a depth of $935 \mathrm{~m}(3068 \mathrm{ft})$ in the first stage, and on May $24-25,1979$, logging continued to a total depth (TD) of $2939 \mathrm{~m}(9642 \mathrm{ft})$ in the second stage. The last $1219 \mathrm{~m}(4000 \mathrm{ft})$ of rocks penetrated are granitic material. During the second stage a temperature log was run to a depth of $2560 \mathrm{~m}$ $(8400 \mathrm{ft})$ where the recorded temperature was $204.4^{\circ} \mathrm{C}\left(400^{\circ} \mathrm{F}\right)$. Just prior to running this $\log$, a maximum logging temperature of $209^{\circ} \mathrm{C}\left(408^{\circ} \mathrm{F}\right)$ was observed on the Densilog ${ }^{\circledR}$ instrument thermometer. Both sets of high temperature geothermal borehole tools were available at the well site. One set was rated to a maximum temperature of $204.4^{\circ} \mathrm{C}\left(400^{\circ} \mathrm{F}\right)$; the other set was rated to $260^{\circ} \mathrm{C}\left(500^{\circ} \mathrm{F}\right)$. 


\section{LOGGING OPERATIONS}

First Stage Logging

$[0-935 \mathrm{~m}(0-3068 \mathrm{ft})]$

The log suite recorded in the first stage included the following logs.

1. Four Arm Caliper Log

2. Spectralog

3. Compensated Densilog/GR-Neutron with Caliper

4. Dual Detector Neutron Lifetime $\log ^{\circledR}$ (DNLL)

5. Induction Electrolog ${ }^{(}$with spontaneous potential (SP) curve

6. BHC Acoustilog ${ }^{\circledR}$

7. Fraclog (variable density/GR)

At the time of logging, the drilling fluid properties were as follows:

Type Density Viscosity pH Fluid Loss Gel Water $1.11 \mathrm{~g} / \mathrm{cm}^{3} \quad 55 \mathrm{sec} \quad 10.3 \quad 20 \mathrm{~cm}^{3}$ (9.3 ppg)

The well fluid resistivity at the bottom hole temperature of $70^{\circ} \mathrm{C}\left(158^{\circ} \mathrm{F}\right)$ was $0.23 \mathrm{ohm}-\mathrm{m}$. The well had been cased to a depth of $135.3 \mathrm{~m}$ (444 ft) by $508 \mathrm{~mm}$ ( $20 \mathrm{in}$ ) casing and drilled to $935 \mathrm{~m}$ (3068 ft) depth with a $444.5 \mathrm{~mm}(17-1 / 2 \mathrm{in})$ bit.

On April 5, 1979, circulation was partially lost when the drilled depth was $935 \mathrm{~m}(3068 \mathrm{ft})$. It was decided to log the well prior to running casing or resuming further drilling. Logging started at $1100 \mathrm{hrs}$, just after circulation stopped. Three maximum recording thermometers were run with each log. A relatively low reading of $70^{\circ} \mathrm{C}$ $\left(158^{\circ} \mathrm{F}\right)$ on the first run and the short time $(5.5$ hrs) since last circulation led to the decision to cancel the temperature log originally scheduled. Instead, a correlation of the time lapse since circulation and of maximum temperatures observed with each logging run was recorded.

\section{April 5, 1979}

1100-2000 hrs Induction Electrolog, Borehole Compensated Acousti. $\log$ and a Four Arm Caliper Log were run. Maximum temperatures recorded were respectively $70^{\circ} \mathrm{C}\left(158^{\circ} \mathrm{F}\right)$, $74.4^{\circ} \mathrm{C}\left(166^{\circ} \mathrm{F}\right)$ and $89.4^{\circ} \mathrm{C}$ $\left(193^{\circ} \mathrm{F}\right)$. Although the hole had been drilled with a
$444.5 \mathrm{~mm}(17-1 / 2 \mathrm{in}) \mathrm{bit}$, the caliper log showed almost the entire drilled section to be of a larger diameter. The fully extended diameter of the caliper arms is $533 \mathrm{~mm}$ (21 in), which was often exceeded.

$2000 \cdot 2400 \mathrm{hrs}$

Calibration and testing of gamma ray Spectralog tool was conducted. Spectralog was run in selected intervals. High readings of total gamma ray counts are mainly reflected on the potassium- 40 curve and to a limited extent, on the thorium curve.

April 6, 1979

0000-0400 hrs Compensated Densilog ${ }^{\circledR} / G R$. Neutron Log with caliper was run. The single arm caliper on the tool string measured a diameter similar to that recorded by the Four Arm Caliper Log, which implies that the hole was badly wash. ed out. The maximum temperature reached $100^{\circ} \mathrm{C}\left(212^{\circ} \mathrm{F}\right)$.

$0400.0900 \mathrm{hrs}$ Problems occured with the electronics on the DNLL tool. After testing and calibration, the log was run. The repeat section of the log was recorded just below the casing because it was considered more prudent to log the upper hole than to risk damaging the tool by repeating at the bottom of the hole. A maximum temperature of $103^{\circ} \mathrm{C}$ $\left(218^{\circ} \mathrm{F}\right)$ was recorded.

Second Stage Logging

[935 - $2939 \mathrm{mn}(3068$ - $9642 \mathrm{ft})]$

The second stage log-suite included the following logs.

1. Induction Electrolog ${ }^{\circledR}$ with SP

2. Borehole Compensated Acoustilog ${ }^{\circledR} / G R$ Log with caliper

3. Fraclog (variable density/signature/GR)

4. Densilog (long space and short space counts)

5. Differential Temperature Log 
The technical condition of the well at this stage follows:

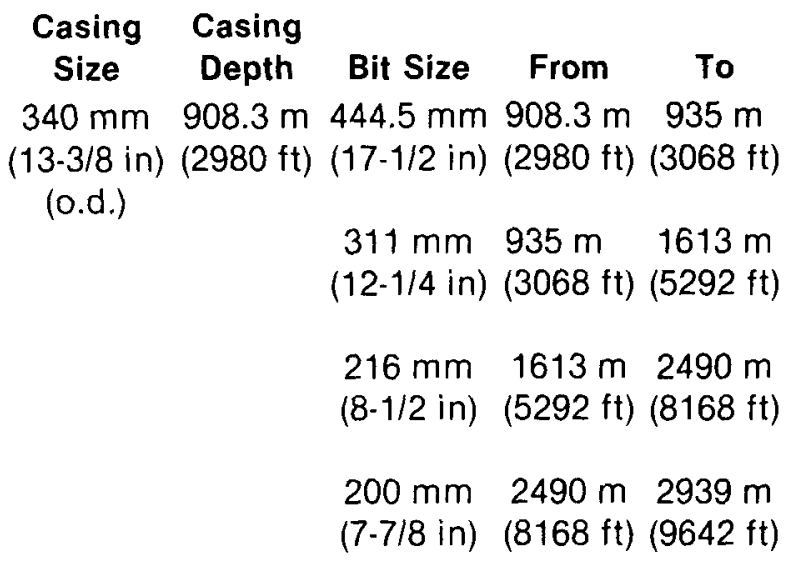

At the time of logging, the borehole fluid properties were as follows:

$\begin{array}{ccccc}\text { Type } & \text { Density } & \text { Viscosity } & \text { pH Fluid Loss } \\ \text { Water } & 1.11 \mathrm{~g} / \mathrm{cm}^{3} & - & 10 & - \\ \text { (Aerated) } & (9.3 \mathrm{ppg}) & & & \end{array}$

May 24, 1979

$1100 \cdot 1225$ hrs The crew prepared for logging with high temperature tools. It was decided later to run tools designed to operate only to $204.4^{\circ} \mathrm{C}\left(400^{\circ} \mathrm{F}\right)$. This necessitated another bridle change because these lower-temperature instruments use multiconductor wireline; whereas, the $260^{\circ} \mathrm{C} \quad\left(500^{\circ} \mathrm{F}\right)$ in. struments use single conductor wireline.

1225. 1600 hrs The Induction Electrolog was run. The maximum temperature recorded was $171^{\circ} \mathrm{C}$ $\left(340^{\circ} \mathrm{F}\right)$.

$1600-2130$ hrs The Compensated Acoustilog was run.

$2130-2400 \mathrm{hrs}$ Problems with compensated density/neutron logging instrument were encountered.

May 25, 1979

$0000-0230 \mathrm{hrs}$ The compensated density/neutron instrument failed. To use the high temperature $\left[260^{\circ} \mathrm{C}\left(500^{\circ} \mathrm{F}\right)\right]$ Den. silog instrument, the cable head would have had to be changed, so it was decided to run the Fraclog first.

$0230.0900 \mathrm{hrs}$ The Fraclog was run with variable density and signature displays.

$0900-1100 \mathrm{hrs}$ The cable head was changed. The crew prepared to run the high temperature Densilog.

$1100-1600$ hrs The Densilog was recorded as a dual trace of long and short spacing counts.

$1600-2000 \mathrm{hrs}$ Problems were encountered with high temperature caliper and temperature instrument. The $204.4^{\circ} \mathrm{C}\left(400^{\circ} \mathrm{F}\right)$ tempera. ture tool was run to $2560 \mathrm{~m}$ $(8400 \mathrm{ft})$, where the temperature reached $204.4^{\circ} \mathrm{C}\left(400^{\circ} \mathrm{F}\right)$. Consequently, the tool was withdrawn and the rest of the logs were cancelled.

The intervals of different logs run in the two stages are shown in Figure 2.

The first logging runs were made to a depth of $935 \mathrm{~m}(3068 \mathrm{ft})$ in a $444.5 \mathrm{~mm}(17-1 / 2 \mathrm{in})$ hole. Surface pipe was set to a depth of $135 \mathrm{~m}$ (444 ft) and only a Gamma Ray log was obtained in this part of the hole. Seven logging runs were made. The Induction Electrolog, BHC Acoustilog, Gamma Ray, Densilog and three-arm caliper log were obtained by Phillips Petroleum Company. The Los Alamos Scientific Laboratory (LASL) obtained the Dual Detector Neutron Lifetime Log, Fraclog, four-arm caliper log, Neutron Log and Spectralog. The logging progressed very efficiently, in part because borehole temperatures were not excessive.

The logging operation at total depth was not so successful as the one conducted at $935 \mathrm{~m}$ (3068 ft). The operation was plagued by high borehole temperature and several tool failures, as mentioned above. During the second logging operation, only the Fraclog was obtained by LASL.

\section{QUALITY OF THE'LOGS}

The logs recorded during the first stage are generally of good quality, but they were affected by the oversize borehole diameter. Accordingly, readings in the washed-out sections are not so reliable. However, no depth correlation problems were encountered. Repeatability 
of the logs and sensitivity of the scales appear to be good. In the washed out sections, the shallow investigating logs - particularly Den-

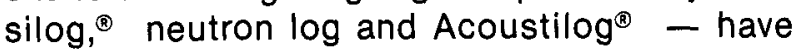
been affected. The washed out borehole diameter was large, often exceeding $533.4 \mathrm{~mm}$ (21 in). To provide good contact with the borehole wall up to a diameter of $559 \mathrm{~mm}$ (22 in), the Densilog was run with an extension arm.

Except for the BHC Acoustilog, the logs recorded during the second stage are also generally of good quality. The BHC Acoustilog shows a 10 to 20 microseconds per foot oscillation over much of the log. Extensive cycle skip. ping occurred due to the high attenuation of acoustic signals in the borehole fluid, which was aerated water. This becomes apparent also by comparing the Acoustilog readings with the first arrival times of acoustic waves on the variable intensity or signature display of the Fraclog. Excessively high temperature in the borehole somewhat affected the log quality.

\section{LOG RESPONSE}

\section{AND ENVIRONMENTAL EFFECTS}

Igneous and metamorphic rocks exhibit entirely different petrophysical properties (porosity, density, acoustic velocity, resistivity and radioactivity) from those presented by sedimentary formations. ${ }^{12.6}$ Mineralogy and petrophysics of non-sedimentary rocks are both important in order to develop an understanding of the log response. Standard logs are designed and keenly tuned to the needs of the petroleum industry. Conventional logging and interpretive methods appear to be not entirely adequate in the case of geothermal wells drilled in volcanics, igneous and metamorphic rocks. Standard calibration of most well logs is satisfactory for sedimentary lithologies. However, for geothermal application, the logging instruments need to be calibrated for the specific purpose. Several effects on the log responses such as those due to mineralization, degree of metamorphism, fracture system and hydrothermal alteration have to be taken into consideration.

Resistivity measurement in a granular rock is affected by porosity, by type of fluid in the pore space and by its petrophysical characteristics. ${ }^{7}$ The mathematical relations are well established for the types of sedimentary formations usually present in the areas explored for oil and gas. However, there is limited validity in using such standard equations as Archie's formula or the Humble formula in a fractured geothermal reservồir. Interpretation of resistivity and/or SP curves in igneous and metamorphic rocks is largely a matter of knowledge of the area and of the amount of corroborating data available.

Induction Electrolog ${ }^{\circledR}$ run in Desert Peak Well B-23-1 includes the conductivity and resistivity curves of the induction log of $1.016 \mathrm{~m}$ (40 in) spacing, $0.4 \mathrm{~m}$ (16 in) normal curve and spontaneous potential. The well was drilled to the depth of $935 \mathrm{~m}(3068 \mathrm{ft})$ with gel-water of weight $1.11 \mathrm{~g} / \mathrm{cm}^{3}(9.3 \mathrm{ppg})$ and of calculated resistivity of $0.23 \mathrm{ohm}-\mathrm{m}$ at $70^{\circ} \mathrm{C}\left(158^{\circ} \mathrm{F}\right)$. Further drilling to the target depth was accomplished with water. To about $1722 \mathrm{~m}$ $(5650 \mathrm{ft})$ deep, induction $\log$ resistivity is observed to be in the range of 1 to $30 \mathrm{ohm}-\mathrm{m}$. Below that depth, it is generally much higher, exceeding $100 \mathrm{ohm}-\mathrm{m}$ in most of the bottom section. Since the conductivity scale $0-1000$ $\mathrm{mmhos} / \mathrm{m}$ is highly insensitive in the lower conductivity range (as is evident in the bottom part of the well), the conductivity curve has been replotted on a $0-100 \mathrm{mmhos} / \mathrm{m}$ scale and is appended to this report.

The resistivity log has been particularly useful in the delineation of the black carbonrich phyllites, which occur sporadically between $1288 \mathrm{~m}(4225 \mathrm{ft})$ and $1722 \mathrm{~m}(5650 \mathrm{ft})$ depth. Induction log resistivity in the phyllite beds is typically less than $10 \mathrm{ohm} \cdot \mathrm{m}$.

The SP curve is broadly featureless through most of the section and has a positive excursion around $1036 \mathrm{~m}(3400 \mathrm{ft})$ which indicates a possible thermal aquifer and large negative excursions at $1295 \mathrm{~m}(4250 \mathrm{ft}), 1387 \mathrm{~m}(4550 \mathrm{ft})$, $1494-1524 \mathrm{~m}(4900-5000 \mathrm{ft})$ and $1646-1707 \mathrm{~m}$ $(5400-5600 \mathrm{ft})$. These negative anomalies probably represent sharp changes in the lithological column and petrophysical variations associated with the phyllite layers.

Compensated Densilog was run on a 1.65 to

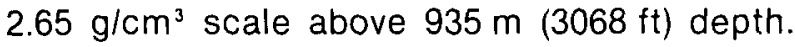
From $935 \mathrm{~m}$ (3068 ft) to TD, Densilog was recorded as a dual trace of short spacing and long spacing in counts per second. The logs show good repeatability in the zones where repeat sections were run. The short spacing and long spacing amplitudes (counts/second) were converted into bulk density $\left(\mathrm{g} / \mathrm{cm}^{3}\right)$ by the use of the calibration chart for the specific tool used and were replotted on a scale of $1.80-2.80$ $\mathrm{g} / \mathrm{cm}^{3}$. Enclosed with this report is a composite log of second stage logging from $911-2938 \mathrm{~m}$ $(2990-9640 \mathrm{ft})$ which incorporates a Densilog ${ }^{\circledR}$ in $\mathrm{g} / \mathrm{cm}^{3}$ on a compatible scale with Acoustilog, ${ }^{\circledR}$ with gamma ray from 0 to $200 \mathrm{API}$ scale and with induction resistivity in 0.100 ohm-m scale. The Densilog appears to be less 
useful in metamorphic and igneous rocks than in sedimentary formations. The densities are usually so high in intrusive rocks and so low in volcanic tuffs that recorded density values may not be as accurate when their readings are outside the calibration range of the probe. Relatively unknown mineral content does not permit matrix or $Z / A$ effects $(Z=$ atomic number, $A=$ atomic weight) to be determined for accurate derivation of bulk densities. Hole diameter also causes problems in the inter. pretation of a density log. Fractures and altered zones frequently cause hole enlargement and rugosity of the borehole wall that significantly affect the log response.

In the first stage, the Compensated Densilog was run in a borehole with a diameter range between $432 \mathrm{~mm}$ (17 in) and $>559 \mathrm{~mm}$ (22 in). The compensation curve shows large, positive corrections applied through most of the section. Consequently the log should be considered reliable in the sections of uniform diameter on the caliper log and of small amplitudes on the correction curve. In washed-out intervals, the limitations associated with the correction capability of the equipment have to be kept in mind.

In the second stage the Densilog is a presentation of the long spacing detector counts and of the short spacing detector counts for which no compensation has been applied. The borehole diameter often exceeds $254 \mathrm{~mm}$ (10 in) above a depth of $1615 \mathrm{~m}(5300 \mathrm{ft})$, but the well diameter is mostly around bit-size below this depth. Although the borehole diameter was smaller, the converted bulk densities in $\mathrm{g} / \mathrm{cm}^{3}$ are likely to be subject to the same effects of wall rugosity.

Compensated Neutron Log was run in the first stage only. The log shows excessively high neutron porosity because of the borehole effects. The bit diameter in the section logged was $444.5 \mathrm{~mm}(17-1 / 2 \mathrm{in})$. Over much of the well the caliper log shows an enlarged borehole with the well diameter exceeding $533 \mathrm{~m}$ (21 in). At certain places the Four-Arm Caliper Log shows a larger borehole diameter than does the single arm caliper of the sidewall compensated density/neutron combination logging instrument. This is usually possible in a rugose borehole

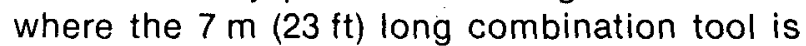
pressed against one side of the borehole wall and where the single eccentric arm touches the opposite side. Borehole diameter effects and the proper porosity corrections on the Compensated Neutron Log are shown in Figure 3 to a maximum borehole diameter of 14 in. ${ }^{12}$ In order to apply corrections needed for larger diameters, the chart has been extrapolated by the empirical relation,

$$
\begin{aligned}
\phi_{\text {corr }} \approx & \phi_{a}[1-0.016(\mathrm{CAL}-7.875)] \\
& -[0.885(\mathrm{CAL}-7.875)] \\
& \times[1-0.03(\mathrm{CAL}-7.875)]
\end{aligned}
$$

where $\phi_{\text {corr }}$ is the corrected value of the apparent compensated neutron reading $\phi_{a}$ (in per cent) and $\mathrm{CAL}$ is the borehole diameter in inches. This approximate relation is equally applicable in the range of borehole sizes from 120 to $356 \mathrm{~mm}(4-3 / 4$ in to $14 \mathrm{in})$. For a $20 \mathrm{~mm}(7-7 / 8 \mathrm{in})$ diameter borehole, for which the equipment was originally calibrated, the correction is zero. In the subject well the apparent neutron porosity readings were corrected by the above relation.

Neutron logs are calibrated in fresh-waterbearing limestones and are scaled in apparent limestone or sandstone porosity units. In this case, compensated neutron is recorded in sandstone porosity units, which means it would read zero in pure quartz. If adequate calibration data for the appropriate lithology types were available, the neutron log could be very useful in the study of geothermal reservoirs in igneous and metamorphic rocks. Unfortunately, this is not the case and quantitative evaluation of porosity from the neutron log alone can not be made. However, in combination with other logs, the neutron log can be used to estimate porosity and to identify zones that are rich in hydrogenous minerals. For additional lithology information, field test studies of comparative runs of thermal-and epithermal-type neutron logs are recommended.

Borehole Compensated Acoustilog ${ }^{\circledR}$ was run on $40-140$ microseconds per foot scale in the first stage to a depth of $935 \mathrm{~m}(3068 \mathrm{ft})$. The tool was centralized in a borehole drilled with a $444.5 \mathrm{~mm}(17-1 / 2 \mathrm{in})$ bit. Therefore, in the large borehole some effect of the fluid on the accuracy of measurement is apparent. On the Acoustilog, ${ }^{\circledast}$ cycle skipping is predominant throughout the second stage run from $914 \mathrm{~m}$ $(3000 \mathrm{ft})$ to TD, thus affecting $\log$ quality. Aerated water in the borehole appears to be the main cause. Acoustic logs are highly sensitive to aerated or gas-cut fluids because both significantly attenuate the acoustic wave amplitudes. Although strong enough to trigger the receiver nearest to the transmitter, the first acoustic arrival is so attenuated that upon reaching the far receiver, it fails to trigger it. This results in the far receiver being triggered by a different, later arrival in the acoustic wave 
train. Hence, the transit interval time measured on the particular acoustic pulse is too long. Accordingly, an Acoustilog will show sudden and large excursions towards higher specific acoustic times. This "cycle skipping" is usually encountered when the signal is highly attenuated by causes such as unconsolidated formations, fractures, aerated or gas cut drilling fluids, a rugose borehole, and high gas saturation in the formation.

The configuration of the Dresser Atlas BHC Acoustilog borehole device is $T_{1} 4 R_{1} 2 R_{2} 4 T_{2}$. It means there is a 4-foot distance between the first transmitter and the first receiver, a 2-foot distance between the two receivers and again a 4-foot distance between the second receiver and the second transmitter. The interval transit time per foot as recorded on the log is computed in the equipment as

$$
\Delta t=\frac{\left(T_{1} R_{2}-T_{1} R_{1}\right)+\left(T_{2} R_{1}-T_{2} R_{2}\right)}{4}
$$

where $T_{1} R_{2}, T_{1} R_{1}, T_{2} R_{1}$ and $T_{2} R_{2}$ are the times expressed in microseconds taken by the acoustic signal to travel from the particular transmitter to the corresponding receiver.

In other words, an average of the times required for the acoustic waves to travel in an upward and downward direction in the formation is computed for a one-foot distance and is recorded on the log as "specific acoustic time" in microseconds per foot. This constitutes the borehole compensation for the unequal travel times through the drilling fluid due to rugose or deviated boreholes.

Acoustic logs can be quite useful in a geothermal well drilled in metamorphic and igneous rocks. The interval transit times in intrusive rocks tend to be quite low. On the other hand, interval transit times in fractured and hydrothermally altered zones would be higher.

The other type of acoustic log run in Desert Peak Well B-23-1 was the Dresser Atlas Fraclog, which displays the full acoustic wave train in amplitude as a function of time. The first run to $935 \mathrm{~m}(3068 \mathrm{ft})$ recorded a variable intensity log, whereas the second run to $2929 \mathrm{~m}$ (9610 ft) recorded the display forms as a variable intensity as well as a signature log. The first arrival times on the variable intensity log could be easily correlated with the BHC Acoustilog readings run in the first stage. Because of frequent cycle skipping, such a correlation was more difficult in the case of Acoustilog in the second stage. Fraclog is a single receiver system with a $122 \mathrm{~mm}(.4 \mathrm{ft})$ spacing between the transmitter and receiver. Assuming a two layer refraction model, formation velocity or specific acoustic time can be calculated from Fraclog using its tool dimensions and the borehole diameter from the caliper log. The following relation for the specific acoustic time can be used.

$$
\Delta t=\frac{X T-2 h \sqrt{\Delta t_{m}{ }^{2}\left(X^{2}+4 h^{2}\right)-T^{2}}}{X^{2}+4 h^{2}}
$$

where $\Delta t=$ specific acoustic time for the formation in microseconds per foot

$\Delta \mathrm{t}_{m}=$ specific acoustic time for the borehole fluid in microseconds per foot

$\mathrm{h}=$ stand-off in feet

$X=$ transmitter-receiver spacing in feet

$T=$ first arrival time on Fraclog in microseconds

The stand-off in the case of centralized tool is:

$$
h=\frac{d-3.375}{24}
$$

where " $d$ " is the borehole diameter in inches and 3.375 is the diameter in inches of the Fraclog tool. If care is taken to pick an interval transit time from Acoustilog, where the log reading is unaffected by cycle skipping, we find the time to be about 55 microseconds per foot in a typical granite section of the bottom part. This correlates well with transit time calculated by the above relation from the first arrival time of the compressional wave on Fraclog.

The gamma ray log has been found to be as useful in igneous and metamorphic rocks as it. has been in sedimentary rocks for the identification of lithology. Rhyolite tuffs can be readily distinguished from basalt dikes in the upper section of the well by their greater gam. ma ray response. ${ }^{2}$

Dresser Atlas Spectralog, a spectral gamma ray device, was run in Desert Peak Well B-23-1 only over a few intervals in the upper section, and it was found to be particularly useful in detecting the presence of potassium rich minerals, such as biotite and feldspars in the interval below $411 \mathrm{~m}(1350 \mathrm{ft})$. Basalt dikes are easily distinguished by low potassium and thorium response. Although the distribution of thorium, uranium and potassium-40 in all nonsedimentary rocks is not yet completely known, the Spectralog is considered to be of immense value for lithological correlation in geothermal wells drilled in volcanic, metamorphic and igneous rocks. The potassium-40 content in igneous rocks is generally dependent upon the abundance of potassium feldspar. On the other 
hand, uranium and thorium may show a large variation depending upon the concentration of certain accessory minerals like zircon and sphene (see Table 1).

\section{TABLE I}

URANIUM AND THORIUM DISTRIBUTION IN CERTAIN ACCESSORY MINERALS

\begin{tabular}{lccc} 
& \multicolumn{1}{c}{$\mathbf{U}$} & Th \\
\cline { 2 - 2 } & $\mathbf{( p p m )}$ & & $\mathbf{( p p m )}$ \\
Allanite & $30-700$ & & $500-5000$ \\
Apatite & $5-150$ & & $20-150$ \\
Epidote & $20-50$ & $50-500$ \\
Monazite & $500-3000$ & $2.5 \times 10^{4}-20 \times 10^{4}$ \\
Sphene & $100-700$ & $100-600$ \\
Xenotime & $500-3.4 \times 10^{4}$ & Low \\
Zircon & $300-3000$ & & $100-2500$
\end{tabular}

Uranium is found to be quite mobile in an oxidizing environment; therefore, fracturing plays a significant role in its migration and precipitation. Thus, Spectralog offers a possibility of finding fractures transmitting hot water in a geothermal well. At the same time, it has also been indicated that potassium -40 may be selectively removed from hydrothermally altered zones and precipitated near the boundaries of such intervals. ${ }^{3}$ Spectralog then could also be used in such cases to define zones of hydrothermal alteration. In Desert Peak Well B-23-1, Spectralog was run only over a few selected intervals above $914 \mathrm{~m}(3000 \mathrm{ft})$; whereas, the Gamma Ray Log was run in both stages through the entire drilled section.

Least affected by the adverse borehole environment, the gamma ray logs are of extremely good quality. In the middle section around $1830 \mathrm{~m}(6000 \mathrm{ft})$ are granite dikes characterized by very high (>200 API) gamma readings and in. terspersed with rocks mainly composed of chlorite schists with hornfels, which are marked by medium gamma response (around 100 API). In the absence of the superior Spectralog, the natural gamma ray log appears to provide the most useful basic information in the identification of lithology.

\section{LOG INTERPRETATION}

The present status of well log interpretation techniques for geothermal exploration is still in its infancy, especially for wells drilled in igneous and metamorphic formations. Although considerable work in this direction has been reported in recent years, there remains a notable gap between petroleum and geother- mal applications of log interpretation methods. There are peculiar problems associated with log interpretation in geothermal wells such as unknown matrix response, unfamiliar lithology, effects of hydrothermal alteration and fracture systems. ${ }^{14}$

Desert Peak Well No. B-23-1 (see Appendix A-I) has encountered a lithological sequence that varies from lacustrine sediments to volcanic flows and tuffs ranging in composition from basalt to rhyolite in the upper half of the well. The lower half of the well consists of phyllites and chlorite schists with hornfels and granite at the bottom. The response of various logging tools in such lithologies is quite uncertain and the main approach has been to identify and correlate the different lithological units on the basis of crossplots and histograms for the log data available.

It is felt that the log suite run during the second stage of logging is inadequate. Neutron log is one of the important logs for lithology identification and crossplot studies. It is desirable to run neutron $\log$ in addition to density and acoustic logs to derive all possible informationabout mineralogy and petrophysics from different combinations of logs. Gamma ray spectral logging also provides necessary supplementary information in such unusual lithologies for the detection of certain minerals.

A multitude of crossplot concepts is available for the study of the rocks based on well log data.4.7.8 Applications of specific crossplot techniques are well developed for petroleum provinces and can be usefully employed for the study of rock sequence in a geothermal well under favorable conditions. An understanding of the basic log response functions greatly assists in defining and evaluating the potential of crossplotting techniques. Three basic, useful logging parameters are the density, neutron porosity and specific acoustic time.

In the case of granular formations, different combinations of these logging parameters provide straightforward solutions in the quantitative determination of porosities and in identification of lithology. In metamorphic and igneous rocks, these crossplots alone are not enough to understand the lithological characteristics and pore structures in such rocks. ${ }^{5}$ It is necessary to combine the statistical approach, standard crossplotting techniques and pattern recognition with a close study of the drill cuttings information to arrive at the characteristic properties of the different lithological units.

The conventional litho-porosity crossplot involes a two-dimensional display of the three 
basic logging parameters - density, neutron porosity and specific acoustic time. The effects of porosity on these parameters is removed by defining the slopes of the matrix-to-fluid-point lines as two lithology-dependent variables, ${ }^{8} \mathrm{M}$ and $N$, such that

$$
\begin{aligned}
& M=\frac{\Delta t_{f}-\Delta t}{\rho_{b}-\rho_{f}} \times .01 \\
& N=\frac{\varnothing_{N}-1}{\rho_{b}-\rho_{f}}
\end{aligned}
$$

A crossplot of these functions $M$ and $N$ can be seen in Figure 4."1 The location of different lithology points is shown including the areas usually occupied by volcanic tuffs. This crossplot technique will be useful in the iden. tification of lithology when volcanic flow tuffs are thought to be present. A basic requirement of this technique is that the log responses for the particular matrix must be known and that complete log data from all three porosity logs are available.

Another approach is the plotting of data for each interval on the basis of the number of points with an identical log response. Depending upon the relative contrast in the log response, these plots, or histograms can be quite useful in distinguishing between the lithological units in the rock sequence.

Both these procedures have been followed in the present study. The log data of Desert Peak Well B-23-1 were digitized for analysis. The traces digitized include gamma ray, density (the long spacing counts per second for the lower section converted into bulk density in $\mathrm{g} / \mathrm{cm}^{3}$ ), specific acoustic time, induction resistivity, compensated neutron porosity (for the upper section only), caliper, potassium-40, uranium, and thorium (for the upper section only). Additionally available log data was used qualitatively. Digitization was done at a sample frequency of every half-foot level. Environmental borehole diameter corrections on the Compensated Neutron Log readings were made. Any other normalization of the data was not attempted because of the uncertainties involved. Crossplots/histograms were made on the computer for a number of zones which were selected on the basis of probable lithology and consistency of log data. Lithological inferences from these studies are quite illustrative and can be very well correlated with the information obtained from the drill cuttings.

General geology of the rocks encountered in Desert Peak Well B-23-1 as described from the cuttings is as follows. ${ }^{13}$ Above $404 \mathrm{~m}(1325 \mathrm{ft})$ depth, the main constituents are basalt, basaltic andesite and andesite of the Chloropagus Formation. These rocks are a series of breccia and lava flows. Between $404 \mathrm{~m}$ $(1325 \mathrm{ft})$ and $1288 \mathrm{~m}(4225 \mathrm{ft})$, a series of andesitic to rhyolitic ash flow tuffs and lava flows have been noticed. They are generally dacitic in composition with reduced amounts of andesite. Several basalt dikes were penetrated in this section. From $1288 \mathrm{~m}$

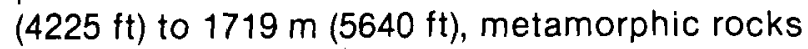
occur with phyllite as the predominant constituent. Phyllites, which are relatively conductive, are clearly marked on the induction log by very low resistivities. This section between $1288 \mathrm{~m}(4225 \mathrm{ft})$ to $1719 \mathrm{~m}(5640 \mathrm{ft})$ is also in. terspersed with zones of quartzite, argillite and chlorite schists. The section between $1719 \mathrm{~m}$ $(5640 \mathrm{ft})$ and $2216 \mathrm{~m}(7270 \mathrm{ft})$ consists of about equal amounts of granite and of chlorite schist with hornfels. A biotite schist was noticed around $1830 \mathrm{~m}(6000 \mathrm{ft})$. The gamma ray $\mathrm{log}$ has been of great help in distinguishing between granite and schist. Below the depth of $2216 \mathrm{~m}$ $(7270 \mathrm{ft})$ to TD, granite was predominant throughout. The granite has been noted to be rich in quartz and poor in mafic minerals. Pyrite in varying quantities is present through the entire section logged.

Log responses for the matrix materials encountered in this well are not very well known. These values may vary over a wide range depending upon rock composition, temperature and pressure. Typical values for density, acoustic and neutron logs for some of these rock types are listed in Table $11 .^{6}$

TABLE \|

\section{MATRIX AND RESPONSE CHARACTERISTICS}

\begin{tabular}{llll} 
ROCK & \multicolumn{1}{c}{$\begin{array}{c}\text { DENSITY } \\
\left(\mathbf{g} / \mathbf{c m}^{3}\right)\end{array}$} & $\begin{array}{c}\text { ACOUSTIC } \\
(\mu \mathbf{s e c / f t )}\end{array}$ & $\begin{array}{c}\text { NEUTRON } \\
\text { (\% porosity) }\end{array}$ \\
Basalt & 2.55 & 61.1 & \\
& $2.0-3.0$ & $47.0 \cdot 101.9$ & \\
Granite & 2.667 & 50.8 & \\
& $2.52 \cdot 2.81$ & $46.8 \cdot 53.5$ & \\
Mica & 2.79 & 60.0 & 6.5 \\
Schist & 2.83 & 49.5 & (Compensated) \\
Phyllite & 2.79 & 58.5 & 8 (Sidewall \\
& 2.89 & 47.5 & Epithermal) \\
Rhyolite & 2.39 & 74.3 & \\
& 2.03 & 93.2 & \\
Tuff & 1.38 & 213.1 & \\
Ash Flow & 2.69 & 62.8 & \\
Tuff & & & \\
Volcanic & 2.19 & 72.2 & \\
Breccia & & &
\end{tabular}


The wide range over which the physical parameters for these rock types can vary limits any quantitative analysis of the zones. Lack of knowledge as to which petrophysical model would apply in the vesicular volcanic rocks and the influence of bound water in associated minerals makes the attempt to estimate the water chemistry in such rocks a formidable task. Even if it is postulated that Archie's basic relation would apply, the value of the porosity exponent and that of porosity itself remain uncertain. This is particularly true in the case of vesicular rocks or altered and fractured rocks which exhibit different degrees of metamor. phism. The complex nature of the pore structures in such rocks would necessitate extensive work in defining the relative behavior of the formation resistivity factor and porosity.

\section{RESULTS}

In spite of incomplete response data for the rocks penetrated in Desert Peak Well B-23-1, it has been possible to perform meaningful semiquantitative $\log$ analysis by computer crossplots/histograms as described below.

Figures 5 through 8 show the densityneutron, density-acoustic, acoustic-neutron and $\mathrm{M}-\mathrm{N}$ plots for a zone of dacite ash-flow tuffs in the interval $725-774 \mathrm{~m}(2380-2540 \mathrm{ft})$. This is a low density zone, reading $1.62 \cdot 1.82 \mathrm{~g} / \mathrm{cm}^{3}$ on Densilog ${ }^{\circledR}$ and showing a corrected compensated neutron apparent limestone porosity of $30-36 \%$. Acoustilog ${ }^{\circledast}$ gives a specific acoustic travel time around 100 microseconds per foot. The low-density tuffs appear to have high vesicular porosity. The Caliper Log frequently records a diameter slightly less than the bit diameter within the zone. Both borehole rugosity and large hole size have affected the Densilog response. Due to the above effects, both parameters, $M$ and $N$, increase in value, shifting the data points in the NE direction on the litho-porosity crossplot (Figure 8.)

A basalt dike in the interval $786.797 \mathrm{~m}$ $(2580-2615 \mathrm{ft})$ is characterized by low potassium-40 response $(2-3 \%)$ on the Spectralog (histogram in Figure 9) reducing the total gamma ray value to the minimum (25 - 30 API) level (histogram in Figure 10), while the bulk density value exceeds the scale on the log $\left(>2.65 \mathrm{~g} / \mathrm{cm}^{3}\right)$ as seen in Figure 11. Compensated Neutron Log response, although corrected empirically for the large borehole diameter, reads rather high $(20 \%)$ as illustrated in Figure 12. Crossplots of neutron, density and acoustic readings are shown in Figures 13 through 15. The litho-porosity crossplot in
Figure 16 gives the values for the parameters $M$ from 0.7 to 0.8 and $N$ around 0.5 in basalt. The higher than expected neutron response is probably due to the presence of some hydrogenous mineral in the rock.

The zone at $893.924 \mathrm{~m}(2930-3030 \mathrm{ft})$ consists of soft bentonitic clay, underlain by rhyolite tuffs. They can be easily distinguished in the potassium-40 and GR histograms in Figures 17 and 18. Rhyolite tuffs contain biotite and felspar crystals, which enhance the potassium-40 response on the Spectralog. The resistivity and density histograms in Figures 19 and 20 also distinguish between the two lithologies, while the neutron response is unable to resolve them (Figure 21).

The crossplots between density, neutron and acoustic readings in Figures 22 through 24 for

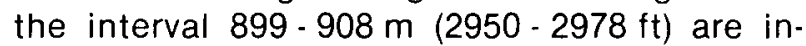
dicative of a typical shale bed usually encountered in a petroleum province. This is also seen on the $\mathrm{M}-\mathrm{N}$ plot in Figure 25. Average density of the bentonitic clay is $2.45 \mathrm{~g} / \mathrm{cm}^{3}$, while the interval transit time and compensated neutron porosity are 100 microseconds per foot and $22 \%$, respectively. In the rhyolite tuffs, these values are $2.0 \mathrm{~g} / \mathrm{cm}^{3}, 80 \mathrm{microseconds}$ per foot and $18 \%$. Figures 26 through 28 show the crossplots for this interval $911.916 \mathrm{~m}$ $(2988-3004 \mathrm{ft})$; whereas, the litho-porosity crossplot is presented in Figure 29. Note that the points are located in the low density tuffs area. It suggests that the zone is permeable. A small negative SP is observed and the Caliper Log reads less than the nominal bit diameter.

The zone $951.971 \mathrm{~m}(3120 \cdot 3186 \mathrm{ft})$ is marked by high radioactivity (GR around $160 \mathrm{API}$ ) probably due to increased biotite and potassium feldspar content within the rhyolite low-density tuff section. GR, density and resistivity histograms for this zone can be seen in Figures 30 through 32. Other crossplot and statistical methods in this interval and below, could not be used because the neutron log is not available and the acoustic log is extensively affected by cycle skipping. Since the gamma ray spectral log also was not run in the second stage of logging, it is difficult to resolve the uncertainties for want of adequate data.

Dacite ash-flow tuffs, encountered between $978 \mathrm{~m}(3210 \mathrm{ft})$ and $1256 \mathrm{~m}(4120 \mathrm{ft})$ vary widely in composition and grain size as indicated from the drill cuttings analysis. Accordingly, the log response also changes to a large extent within the interval. Varying amounts of feldspar and biotite crystals were noticed in the cuttings, and the degree of alteration and silicification with sporadic presence of gravels were ob- 
served. The zone $1204-1241 \mathrm{~m}$ (3950 - $4070 \mathrm{ft})$ shows a typical low to medium GR response (50.85 API) in dacite-flow tuffs, while the density is relatively higher (around $2.30 \mathrm{~g} / \mathrm{cm}^{3}$ ). Resistivity is around $20 \mathrm{ohm}-\mathrm{m}$. Histograms in Figures 33 through 35 show these characteristics for the zone.

Immediately below the thick sequence of rhyolite and dacite ash-flow tuffs, a series of phyllite layers are encountered from $1280-1722 \mathrm{~m}(4200-5650 \mathrm{ft})$. These layers can be identified primarily by lower resistivity on Induction Electrolog. ${ }^{\circledast}$ Both gamma ray and density logs are unable to distinguish them from the adjacent layers composed of ash-flow tuffs in the upper part and chlorite schist in the lower part. Figures 36 through 38 present the GR, density and resistivity histograms for the zone

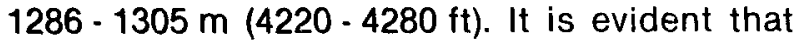
the GR and density readings (around $75 \mathrm{API}$ and $2.2 \mathrm{~g} / \mathrm{cm}^{3}$ ) are about the same as in dacite tuffs; whereas, the resistivity $(<10 \mathrm{ohm}-\mathrm{m})$ is much lower. The zone $1256-1399 \mathrm{~m}(4450-4590 \mathrm{ft})$ also exhibits the same characteristics as can be seen in Figures 39 through 41 . The phyllite layer at $1500.1537 \mathrm{~m}(4920.5044 \mathrm{ft})$ is characterized by slightly higher readings on the GR $\log (85-105 \mathrm{API})$ and Densilog ${ }^{\circledast}$ (2.2 to 2.6 $\mathrm{g} / \mathrm{cm}^{3}$ ); whereas, the resistivity is extremely low, decreasing to less than $1 \mathrm{ohm}-\mathrm{m}$. The lower part of this zone is washed out. The GR, density and resistivity histograms are shown in Figures 42 through 44.

Another phyllite layer is marked by low density coupled with very low resistivity around $1646 \mathrm{~m}(5400 \mathrm{ft})$. While the GR response does not distinguish phyllite from chlorite schist (Figure 45), density and resistivity clearly distinguish the two lithologies (Figures 46 and 47).

The rock sequence below $1719 \mathrm{~m}(5640 \mathrm{ft})$ consists of granite and chlorite schists with hornfels. A number of granite dikes are noticed intermittently within massive chlorite schist, and as the depth increases, granite becomes predominant towards the bottom of the well. Both lithologies are marked by higher density and resistivity values. Densilog and resistivity logs, therefore, can not be employed in order to distinguish between these lithologies. The gamma ray log, however, appears to be very useful to distinguish between these two rock types since granite is characterized by much higher radioactivity than is chlorite schist. In the interval $1722-1823 \mathrm{~m}$ (5650-5980 ft), the GR log reads $>200$ API in a number of granite dikes present in the section, while the layers of chlorite schists with hornfels are marked by a
GR response between 70 and $115 \mathrm{API}$ units. While the GR histogram in Figure 48 depicts two distinct sets of values, only a single peak (hence, no differentiation) is shown in the density histogram (Figure 49). The large concentration of points around 200 API value is due to the fact that the gamma ray log goes out of scale over granite at a number of places and that no back-up scale values were recorded on the log.

In the bottom section $2216 \mathrm{~m}(7270 \mathrm{ft})$ to TD, typical density and GR values are around 2.60 $\mathrm{g} / \mathrm{cm}^{3}$ and 125 API units. These zones are constituted of relatively fresh granite, rich in quartz. Three sets of GR and density histograms in the zones $2228.2243 \mathrm{~m}$ $(7310-7360 \mathrm{ft}), \quad 2597-2611 \mathrm{~m} \quad(8520-8566 \mathrm{ft})$ and $2630-2643 \mathrm{~m}(8630-8670 \mathrm{ft})$ are presented in Figures 50 through 55.

The zones selected for conventional computer processed crossplots/histograms exhibited reliability and consistency of the log data. This has been done to illustrate the drastic variations in mineral composition of the rocks encountered, to show their effects on the log responses, and to define problems of $\log$ interpretation in unusual lithologies. As pointed out previously, detailed analysis as to the quantitative delineation of permeable layers, as to their lithological composition and as to their fluid production capacity would require more complete logging data and additional experience in the particular geologic environment. To provide accurate interpretive answers to the geological and petrophysical problems in unusual lithologies, it is necessary to have calibration data for hydrothermally altered rocks and realistic geological models. Core analysis data plotted against log responses will be a basic requisite for meeting this objective. Borehole gamma ray spectral analysis will provide an invaluable aid in the analysis of rock types and mineral content as well as in identify. ing zones of hydrothermal alteration.

Acoustic Fraclog has been run over the total section drilled in Desert Peak Well B-23-1. The two displays in the form of variable intensity and signature logs depict the complete acoustic wave train as it reaches the receiver of the logging tool. The amplitude of the received signal is recorded over a certain time range as the variable intensity log or as the signature log respectively. Variations in amplitude are indicated by a succession of changes in brightness or by the deflections of traces from horizontal. Usually the interpretation of the acoustic Fraclog is qualitative and empirical. It is largely based upon the amplitude of shear waves, which are recorded sometime after the 
first arrival of compressional waves. Such logderived information has also to be corroborated by core and drilling data because layer boundaries and healed fractures may give response similiar to open fractures.

Considerable experience and knowledge of the formations are necessary for interpreting the Fraclog. Detection of fractures from the Fraclog essentially involves the determination of shear wave signal, which usually arrives at the receiver after 1.5 to 1.8 times the first arrival time of the compressional wave ${ }^{9}$ (See Figure 56). Shear waves can also be recognized by the change in slope of the bands on the variable intensity display. Indentification of fractures implies the recognition of levels where the shear waves are highly attenuated as can be seen in the areas marked in Figure 56. ${ }^{10}$ Other important factors are the presence of gas in the drilling fluid, which could attenuate the acoustic signals, and centralization of the tool.

In Desert Peak Well B-23-1, the Fraclog in the second stage of logging shows the presence of fractures in a number of intervals. For example, highly attenuated shear waves observed on the Fraclog indicate fractures at $2496.3 \mathrm{~m}(8190 \mathrm{ft})$, $2502.1 \mathrm{~m} \quad(8209 \mathrm{ft}), 2511 \mathrm{~m} \quad(8420 \mathrm{ft}), 2523 \mathrm{~m}$ $(8278 \mathrm{ft}), 2531.4 \mathrm{~m}(8305 \mathrm{ft}), 2535.3 \mathrm{~m}(8318 \mathrm{ft})$ and $2557.3 \mathrm{~m}(8390 \mathrm{ft})$. Since these depths correspond to the Fraclog, which is noted to be $1.83 \mathrm{~m}(6 \mathrm{ft})$ deeper than other logs, the proper depth corrections have to be applied. The interval $2500 \cdot 2560 \mathrm{~m}(8200-8400 \mathrm{ft})$ is understood to have indicated the presence of fractured zones during drilling operations.

The temperature log run from 244 to $2560 \mathrm{~m}$ $(800-8400 \mathrm{ft})$ in Desert Peak Well B-23-1 shows a uniformly high temperature gradient of $11.7^{\circ} \mathrm{C}$ per $100 \mathrm{~m}\left(6.4^{\circ} \mathrm{F}\right.$ per $\left.100 \mathrm{ft}\right)$ from 244 to $671 \mathrm{~m}$ $(800-2200 \mathrm{ft})$. From 671 to $1006 \mathrm{~m}(220-3300 \mathrm{ft})$ the temperature gradient is slightly less, $10.9^{\circ} \mathrm{C}$ per $100 \mathrm{~m}\left(6^{\circ} \mathrm{F}\right.$ per $\left.100 \mathrm{ft}\right)$. Temperatures at

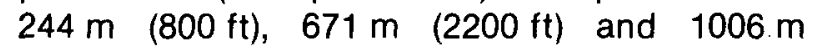
$(3300 \mathrm{ft})$ are recorded as $69.4^{\circ} \mathrm{C}\left(157^{\circ} \mathrm{F}\right), 119.4^{\circ} \mathrm{C}$ $\left(247^{\circ} \mathrm{F}\right)$ and $155.5^{\circ} \mathrm{C}\left(312^{\circ} \mathrm{F}\right)$. An anomalous peak on the temperature $\log$ around $1036 \mathrm{~m}$ $(3400 \mathrm{ft})$ is prominent; but thereafter, the temperature remains almost constant at $163^{\circ} \mathrm{C}$ $\left(325^{\circ} \mathrm{F}\right)$ in the interval $1067-1372 \mathrm{~m}$ (3500- $4500 \mathrm{ft}$ ). A possible explanation for this behavior could be crossflow of hot water over this section in the upward direction. The zone around $1036 \mathrm{~m}(3400 \mathrm{ft})$ could be a porous rock, which is basically low density dacite tuff, exhibiting a low formation pressure. The anomalous SP curve response opposite this zone might be due to a streaming potential (electrokinetic effect). This explanation re- mains to be verified from additional data. The

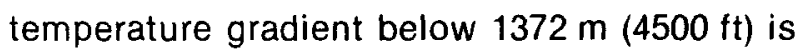
drastically reduced at $4.6^{\circ} \mathrm{C}$ per $100 \mathrm{~m}\left(2.5^{\circ} \mathrm{F}\right.$ per $100 \mathrm{ft}$ ) and continues at this level gradually to a final value of $1.84^{\circ} \mathrm{C}$ per $100 \mathrm{~m}\left(1^{\circ} \mathrm{F}\right.$ per $100 \mathrm{ft})$ at $2560 \mathrm{~m}(8400 \mathrm{ft})$, where the absolute temperature is measured to be $204.4^{\circ} \mathrm{C}\left(400^{\circ} \mathrm{F}\right)$.

A composite log from density, acoustic, gamma ray and induction resistivity logs has been prepared on compatible porosity scales and attached in the Appendix. On the two logs the scales on the right tracks are $1.80 \mathrm{~g} / \mathrm{cm}^{3}$ to 2.80 $\mathrm{g} / \mathrm{cm}^{3}$ for bulk densities and are 124 microseconds per foot to 44 microseconds per foot for the specific acoustic travel times. This porosity overlay greatly assists in quick-look identification of zones affected by adverse borehole conditions or in gauge-hole identification specific formation characteristics.

Induction Electrolog ${ }^{\circledR}$ has been replotted on a more sensitive conductivity scale (0-100 $\mathrm{mmhos} / \mathrm{m}$ ) to highlight the variations in the low conductivity range.

Spectralog sometimes has amplitude scales for uranium and thorium that are rather insensitive when recorded on standard tracks. Therefore, all three curves recording the content of potassium -40 , uranium and thorium have been replotted on three equal tracks on more sensitive scales. The thorium-potassium, uranium-potassium and uranium-thorium ratios computed from these curves are also presented on standard log format. This information will facilitate further study of gamma ray spectral data. Both plots are attached.

\section{CONCLUSIONS AND RECOMMMENDATIONS}

1. Geothermal Desert Peak Well B-23-1 has been successfully logged to the drilled depth of $2939 \mathrm{~m} \quad(9642 \mathrm{ft})$, where the borehole temperature exceeded $204.4^{\circ} \mathrm{C}$ $\left(400^{\circ} \mathrm{F}\right)$. The quality of the logs run is generally quite good except for the Acoustilog ${ }^{\circledR}$ run in the second stage, which is affected by the presence of aerated borehole fluid.

2. Although the log data obtained is limited and a more complete log-suite would have greatly assisted log interpretation, combination of drill cuttings data with gamma ray $\log$, Spectralog, resistivity and porosity logs allowed a semi-quantitative analysis of a rather complex lithological sequence by the use of an empirical, statistical approach.

3. The well logs displayed basically two sets of lithologies. The upper section is con- 
stituted of volcanic rocks, primarily dacite and rhyolite tuffs with a few basalt dikes. The lower section contains phyllite and chlorite schist with hornfels interspersed with granite dikes and thick, fresh granite at the bottom.

4. Phyllites exhibited a distinct response on Induction Electrolog ${ }^{\circledR}$ /SP log showing markedly lower resistivities and negative SP deflections. Chlorite schist and granite layers could be easily identified by their characteristic gamma ray responses. The entire rock sequence could be divided into a number of distinct zones based on their lithological compositions.

5. The presence of a permeable zone around $1034 \mathrm{~m}(3400 \mathrm{ft})$ is indicated. Possible production is expected from fault planes/fractured zones within the dense rocks below a depth of about $2500 \mathrm{~m}(8200 \mathrm{ft}$ ).

6. Geophysical well logs provide important information about the lithological properties of volcanic, metamorphic and igneous rocks. Upgrading of results requires calibration data in such geological models and in hydrothermally altered rocks.

7. On future test wells it is recommended to run all three porosity logs, such as Acoustilog, ${ }^{\oplus}$ Densilog ${ }^{\circledR}$ and neutron log. Their combined information is essential for a more complete evaluation of the rocks penetrated in a geothermal well.

8. Gamma ray spectral log can be of immense value in wells penetrating unusual lithological sequence. Gamma ray spectral information should be an integral part of geothermal logging suites in igneous and metamorphic rocks.

9. Comparative response studies of thermal and epithermal neutron logs is recommended in future test wells.

10. Proper planning of geothermal logging suites and log calibrations, and correlation of geologic, drilling and logging information is a must.

\section{ACKNOWLEDGMENT}

Thanks are due to Mr. W. R. Benoit, Geologist, Geothermal Operations, Phillips Petroleum Company, Reno District, Nevada for useful discussions on the geologic sequence encountered in the well.

\section{REFERENCES:}

1. H. N. Edmundson, and L. L. Raymer, "Table of Radioactive Logging Parameters of Common Minerals," Paper BB - Sixth European SPWLA Symposium Transactions, London, England (March 1979).
2. W. H. FertI, "Gamma Ray Spectral Data Assists in Complex Formation Evaluation," Paper Q - Sixth European SPWLA Symposium Transactions, London, England (March 1979).

3. W. S. Keys, "Borehole Geophysics in Igneous and Metamorphic Rocks," 20th Annual SPWLA Symposium Transactions, Tulsa, Oklahoma (June 1979).

4. W. H. Fertl, "Open Hole Crossplot Concepts - a Powerful Technique in Well Log Analysis," European Offshore Petroleum Conference and Exhibition, London, England (October 1978).

5. S. K. Sanyal, S. Juprasert, and $M$. Jusbasche, "An Evaluation of a RhyoliteBasalt - Volcanic Ash Sequence from Well Logs," SPWLA 20th Annual Logging Symposium Transactions, Tulsa, Oklahoma (June 1979).

6. L. E. Wells, S. K. Sanyal, and M. A. Matthews, "Matrix and Response Characteristics for Sonic, Density and Neutron," SPWLA 20th Annual Logging Symposium Transactions, Tulsa, Oklahoma (June 1979).

7. D. K. Sethi, "Some Considerations about the Formation Resistivity Factor - Porosity Relations," SPWLA 20th Annual Logging Symposium Transactions, Tulsa, Oklahoma (June 1979).

8. J. A. Burke, R. L. Campbell, Jr., and A. W. Schmidt, "The Litho-porosity Crossplot," The Log Analyst (November-December 1969).

9. R. T. Shanks, B. S. Kwon, and M. R. DeVries, "A Review of Fracture Detection with Well Logs," Paper - SPE 6159 (October 1976).

10. J. D. Heflin, "Fracture Detection in West Coast Reservoirs Using Well Logs," Paper - SPE 7976 (April 1979).

11. Dresser Atlas Log Interpretation Chart Manual, 1977.

12. Dresser Atlas Log Interpretation Chart Manual, 1979.

13. W. R. Benoit, Geologist, Geothermal Operations, Phillips Petroleum Co., personal communication (July 1979).

14. S. K. Sanyal, L. E. Wells, and R. E. Bickham, "Geothermal Well Log Interpretation," Midterm Report of Scientific Software Corporation for D.O.E. (February 1979). 


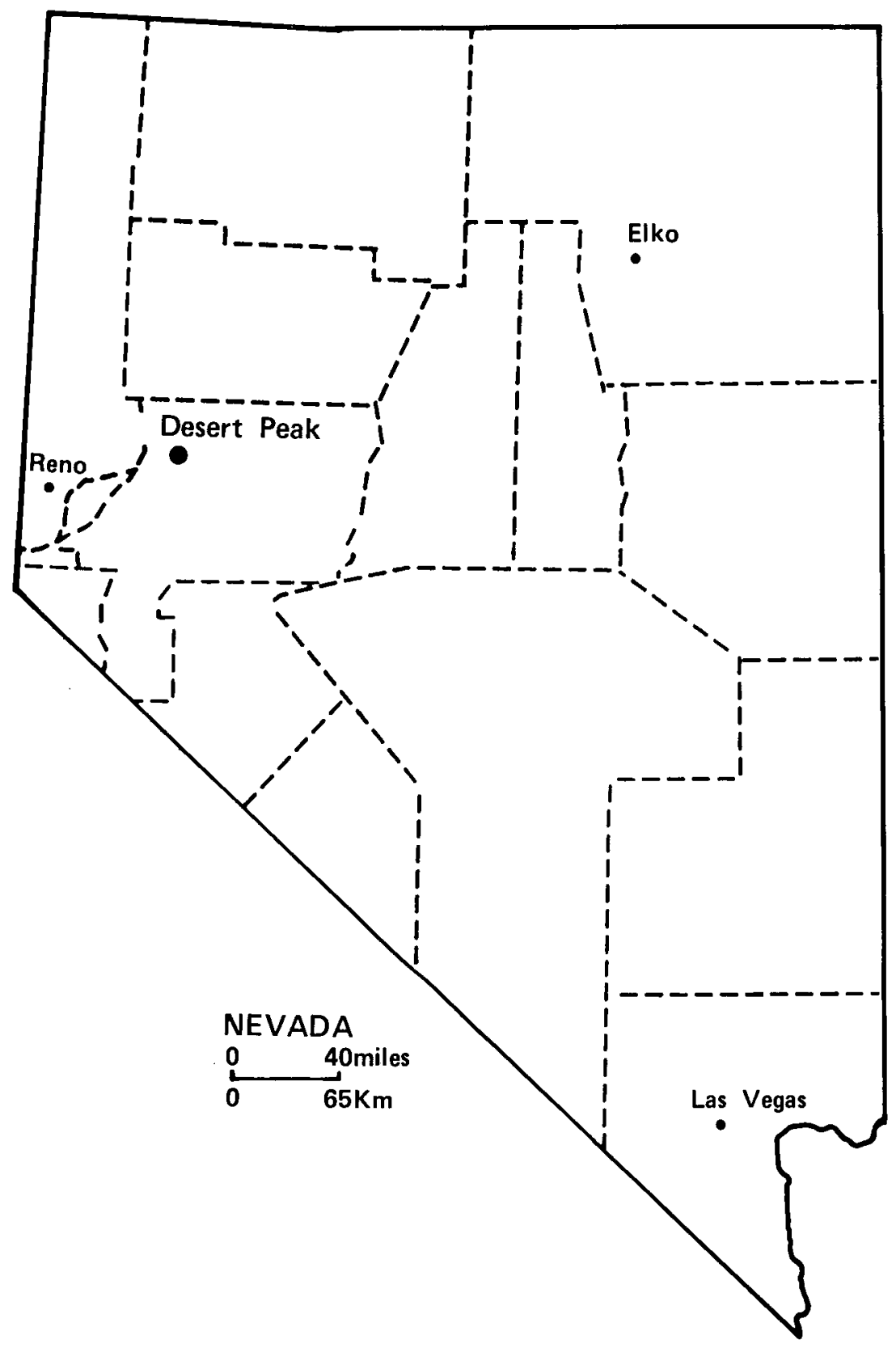

FIGURE 1. Location of Desert Peak Field 


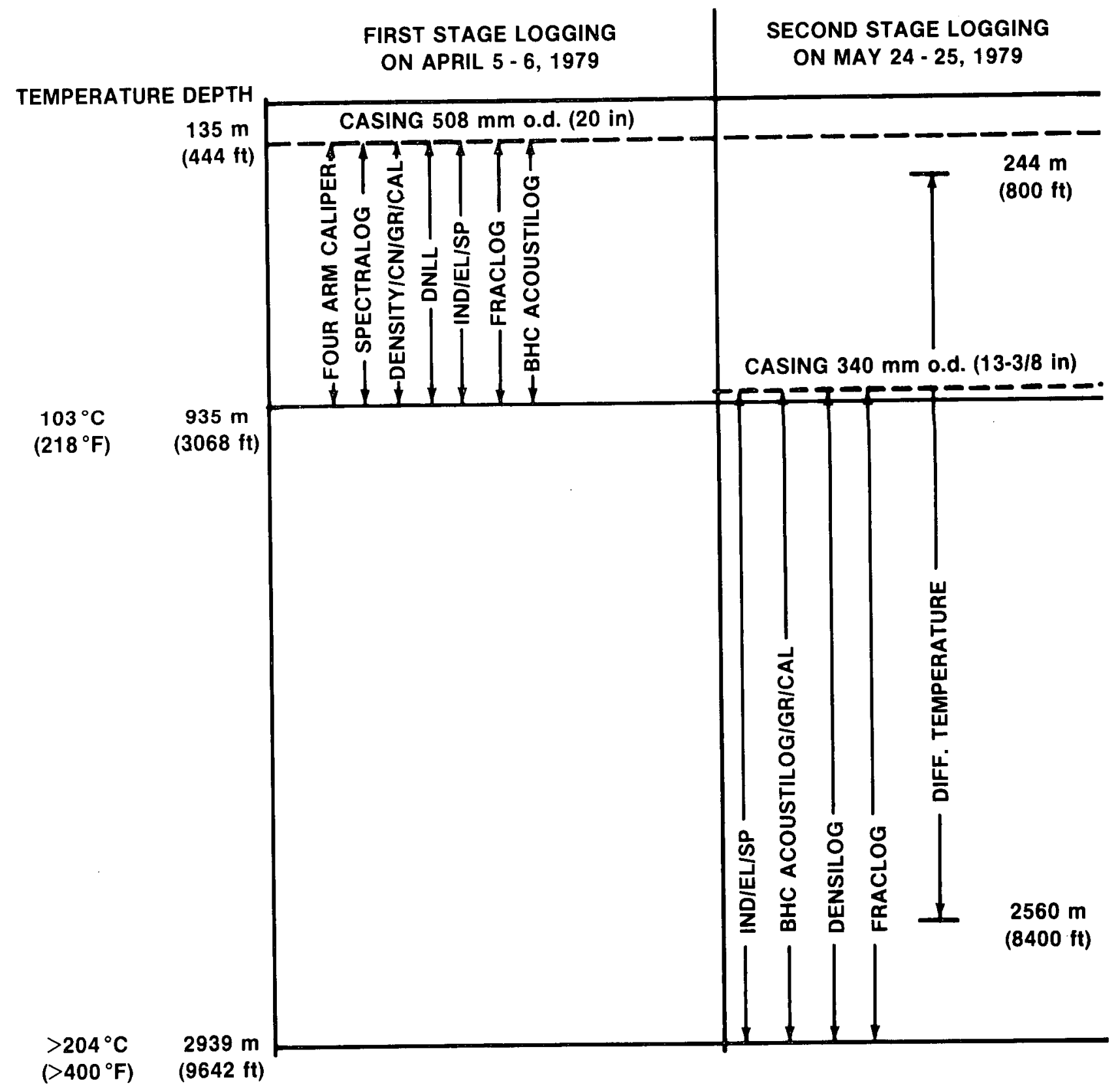

FIGURE 2. Geophysical well logs run in Desert Peak Well B-23-1 


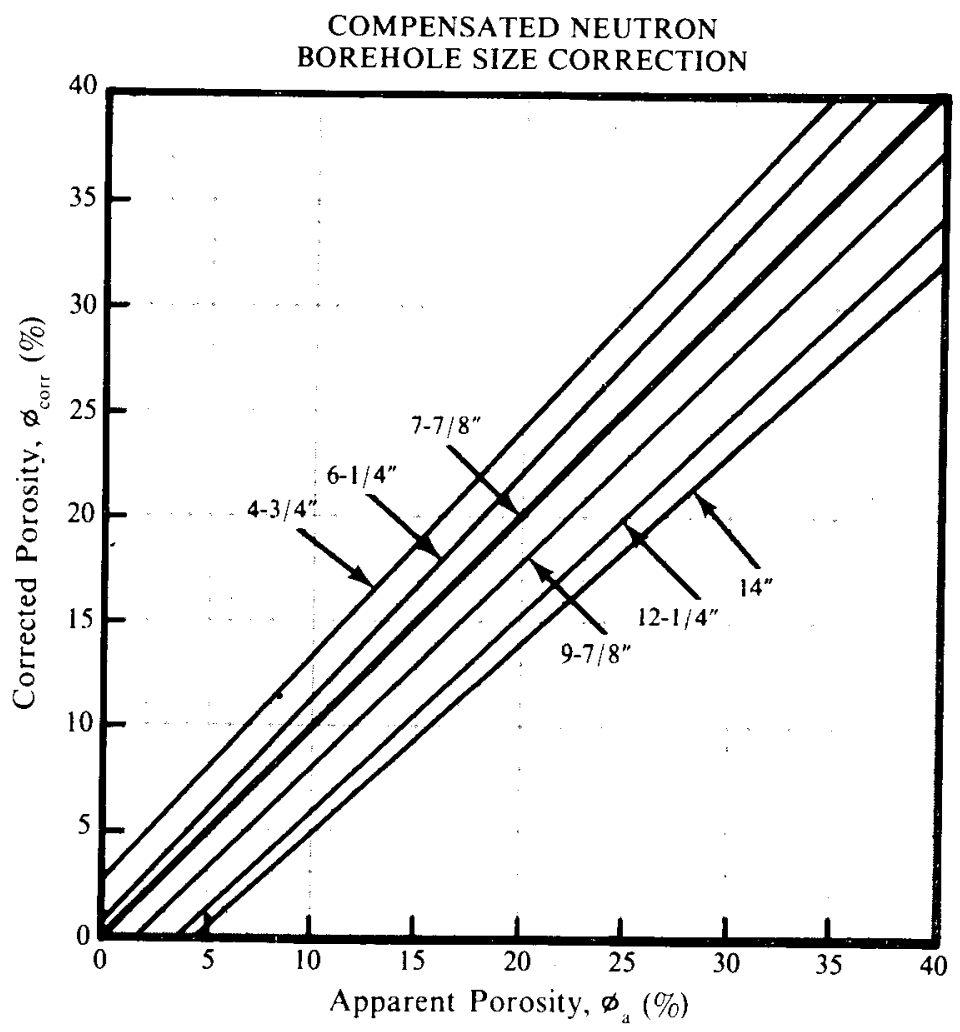

EQUATIONS:

BOREHOLE SIZE CORRECTION

$$
\begin{aligned}
& 4-3 / 4 " \quad \varnothing_{\text {corr }}=1.057 \varnothing_{\mathrm{a}}+3 \\
& 6-1 / 4 " \varnothing_{\text {corr }}=1.054 \phi_{\text {a }}+1.5 \\
& 7-7 / 8^{\prime \prime} \quad \varnothing_{\mathrm{a}}=\varnothing_{\text {corr }} \\
& 9-7 / 8 " \varnothing_{\text {curr }}=0.965 \varnothing_{\text {a }}-1.667 \\
& 12-1 / 4^{\prime \prime} \varnothing_{\text {curr }}=0.925 \varnothing_{a}-3.333 \\
& 14 " \quad \varnothing_{\text {curr }}=0.902 \varnothing_{\mathrm{a}}-4.286
\end{aligned}
$$

FIGURE 3. Borehole size correction on Compensated Neutron (after Ref. 12) 


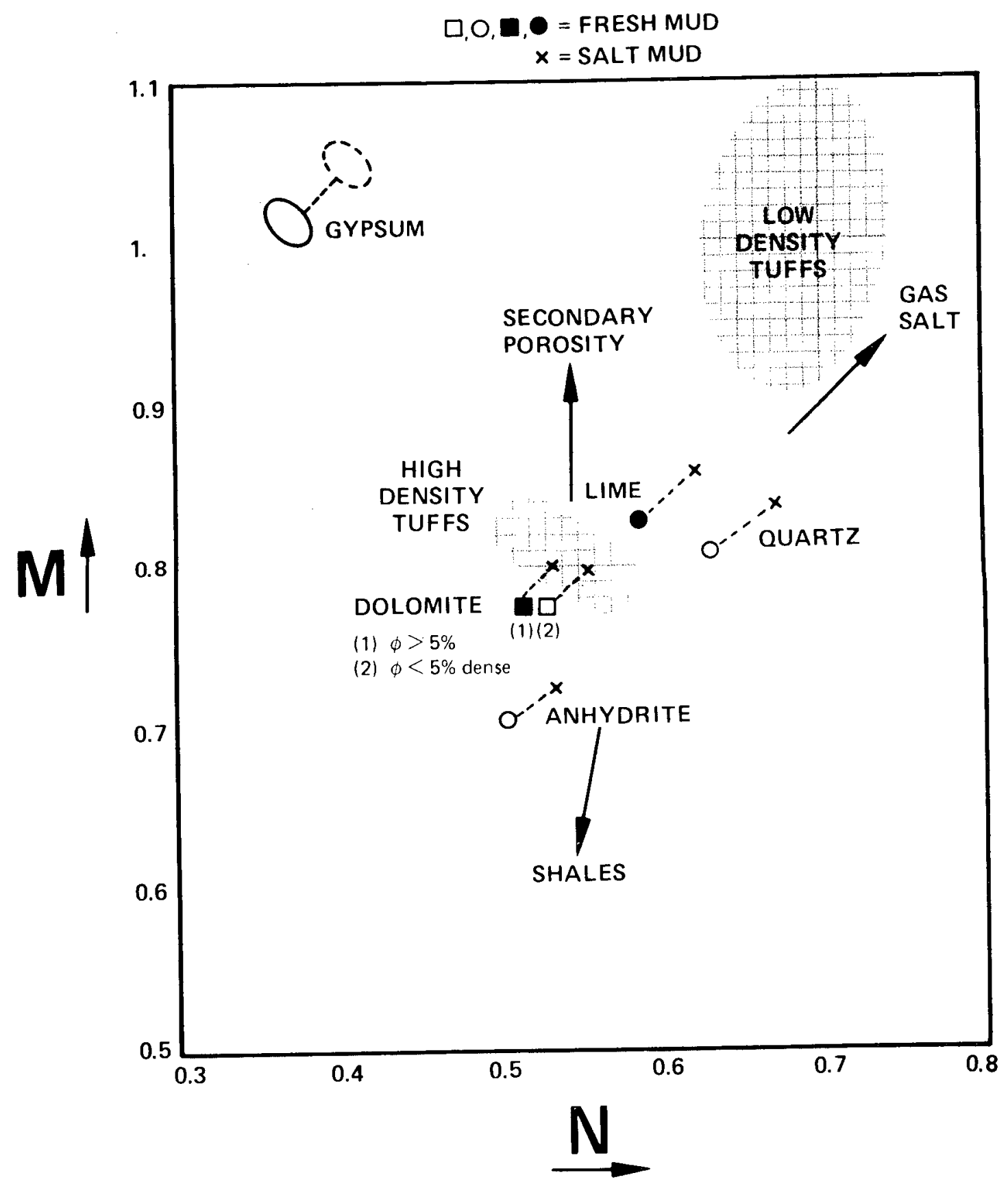

TUFFS SHOWN BY SHADOW AREAS

(For Fresh Mud)

FIGURE 4. Litho-porosity plot (after Ref. 11) 


\title{
SYMBOLS AND SCALES USED IN FIGURES 5 THROUGH 55
}

\author{
DEN Density values, $\mathrm{g} / \mathrm{cm}^{3}$. \\ CN Compensated Neutron Porosity, \% Limestone Units. \\ AC Specific Acoustic Time, microseconds/ft. \\ $\% \quad$ Percent fraction of total number of points. \\ POT Potassium - 40 response, \%. \\ GR Gamma Ray response, API units. \\ RT Induction Resistivity, ohm-m.
}

The numbers/letters on the crossplots indicate the number of points having similar values.

The numbers 1 through 9 indicate the corresponding frequency numbers, while the letters $A$ through $\mathrm{P}$ denote the frequency numbers 10 to 25 in alphabetical order.

An asterisk denotes a frequency number greater than 25 . 
PHILLIPS PETROLEUM COMPAVY

NESERT PEAK WELL B-23-1

CN VS. DEV

$2380 .-2540$.

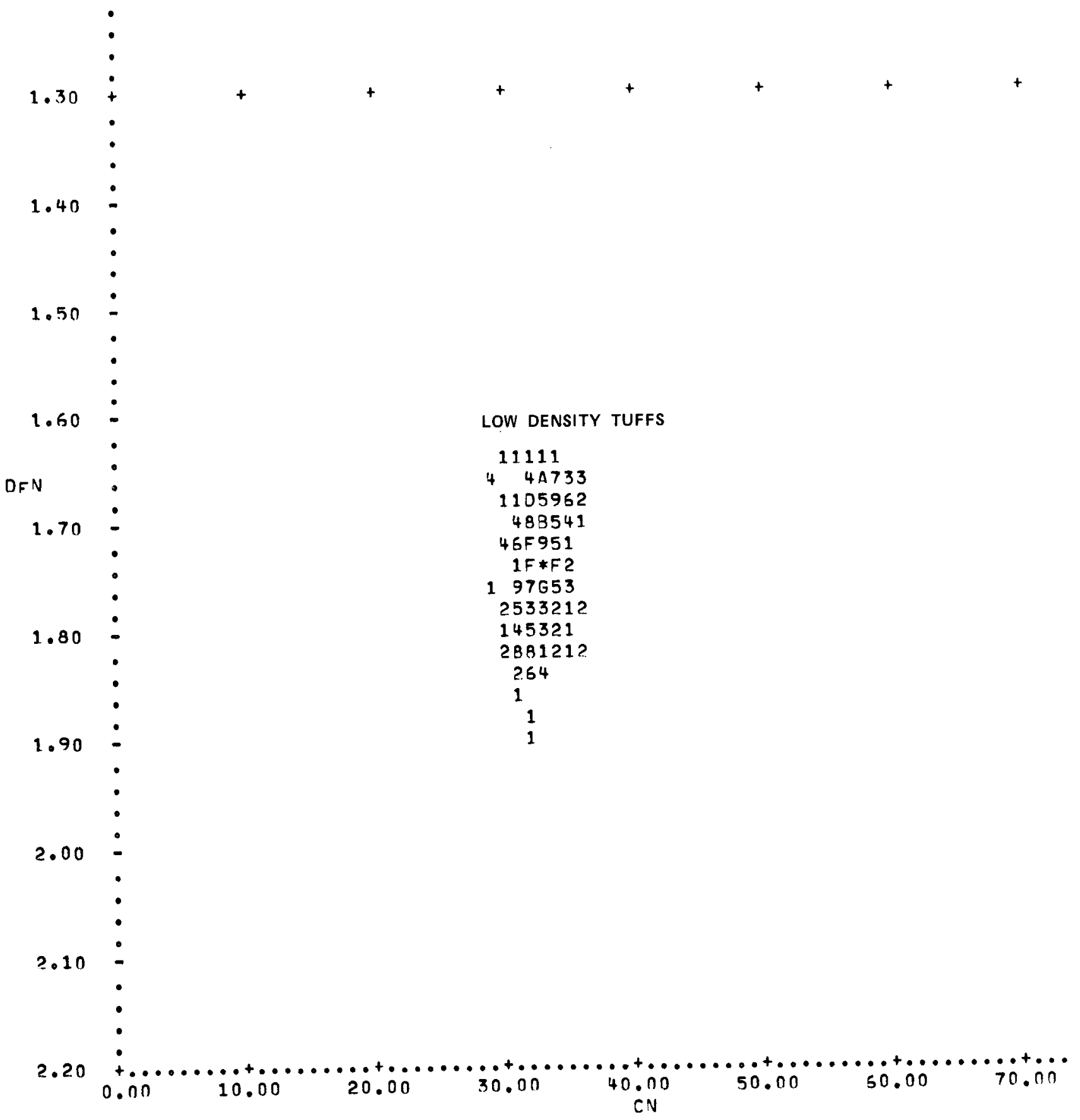

FIGURE 5. Crossplot of Density vs. Compensated Neutron porosity
11111

44733

$1 F * F 2$

2.54

1 
PHILLTPS PETROLEUM COMPAVY

DESERT PEAK WELL $B-23-1$

AC VS. DEV

$2380 .-2540$.

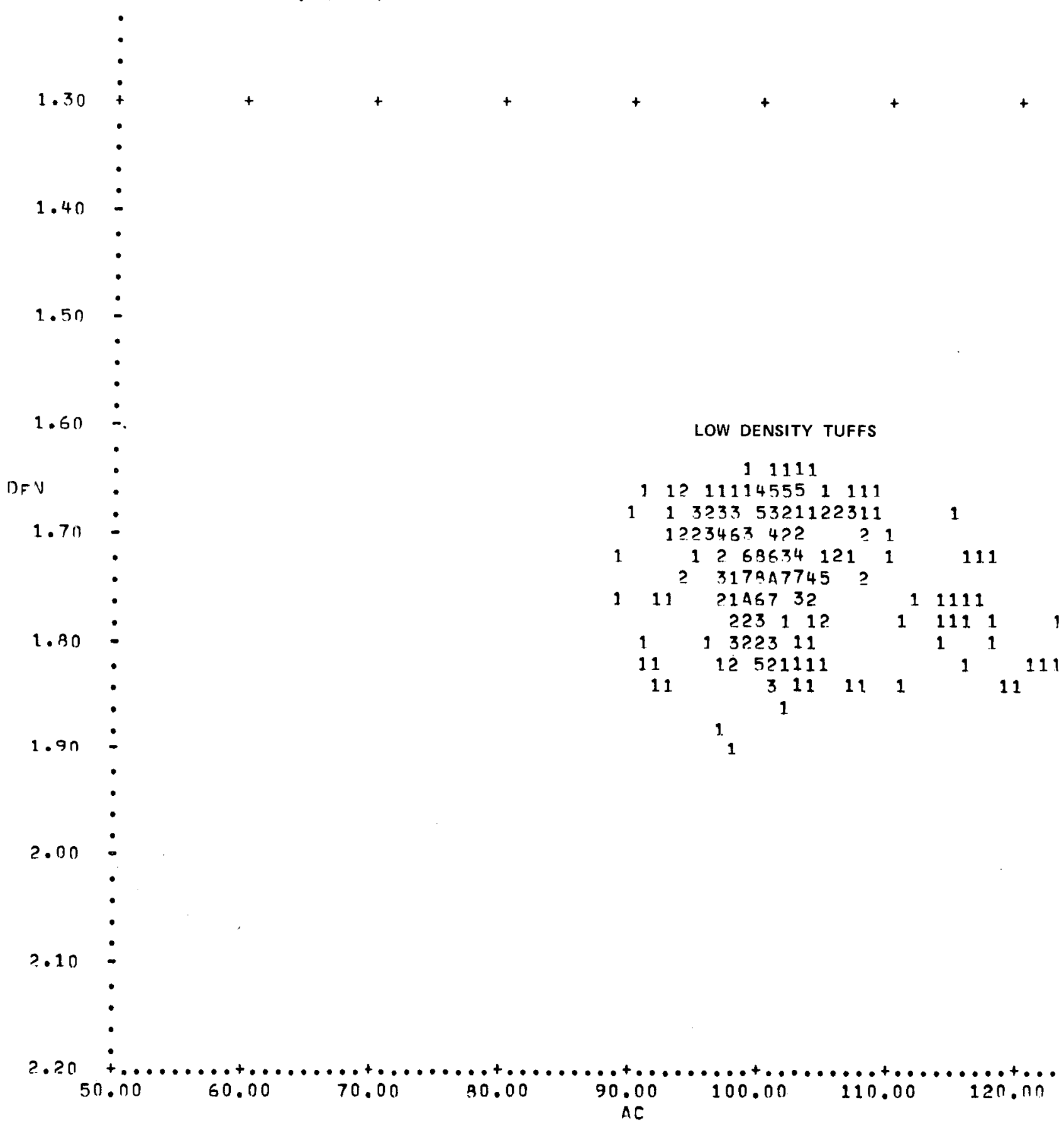

FIGURE 6. Crossplot of Density vs. specific Acoustic time 


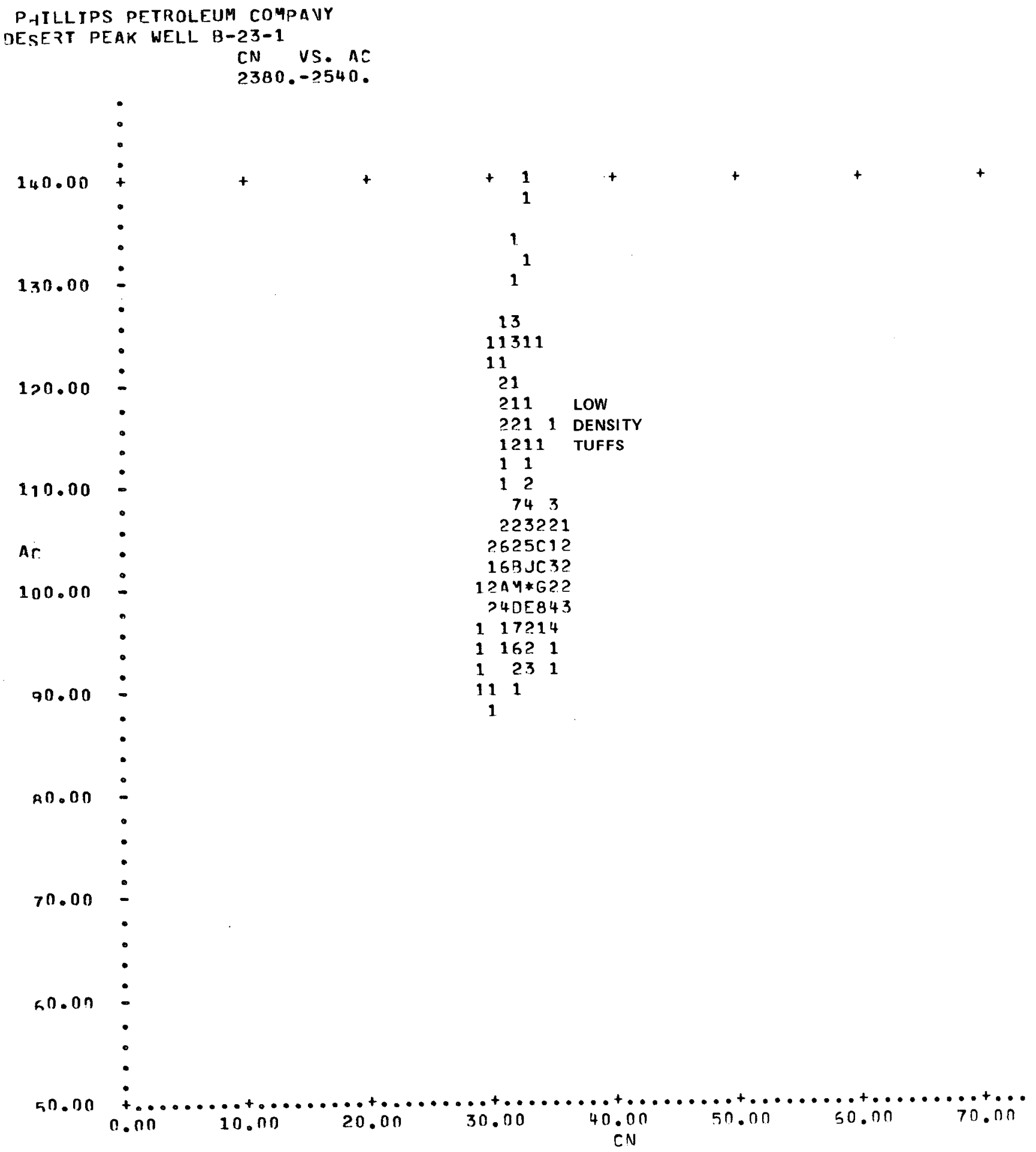

FIGURE 7. Crossplot of specific Acoustic time vs. Compensated Neutron porosity 


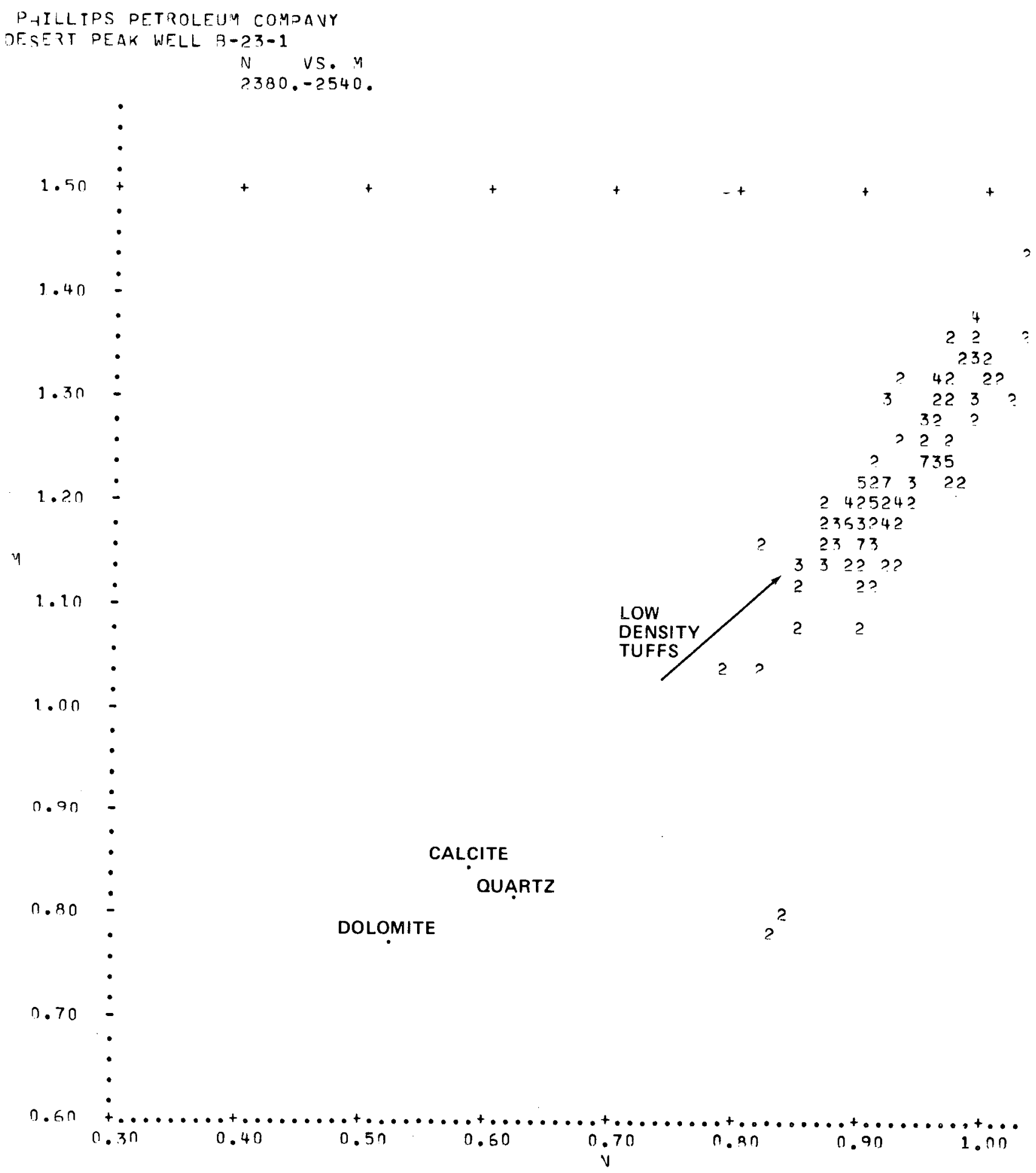

FIGURE 8. M - N Plot 


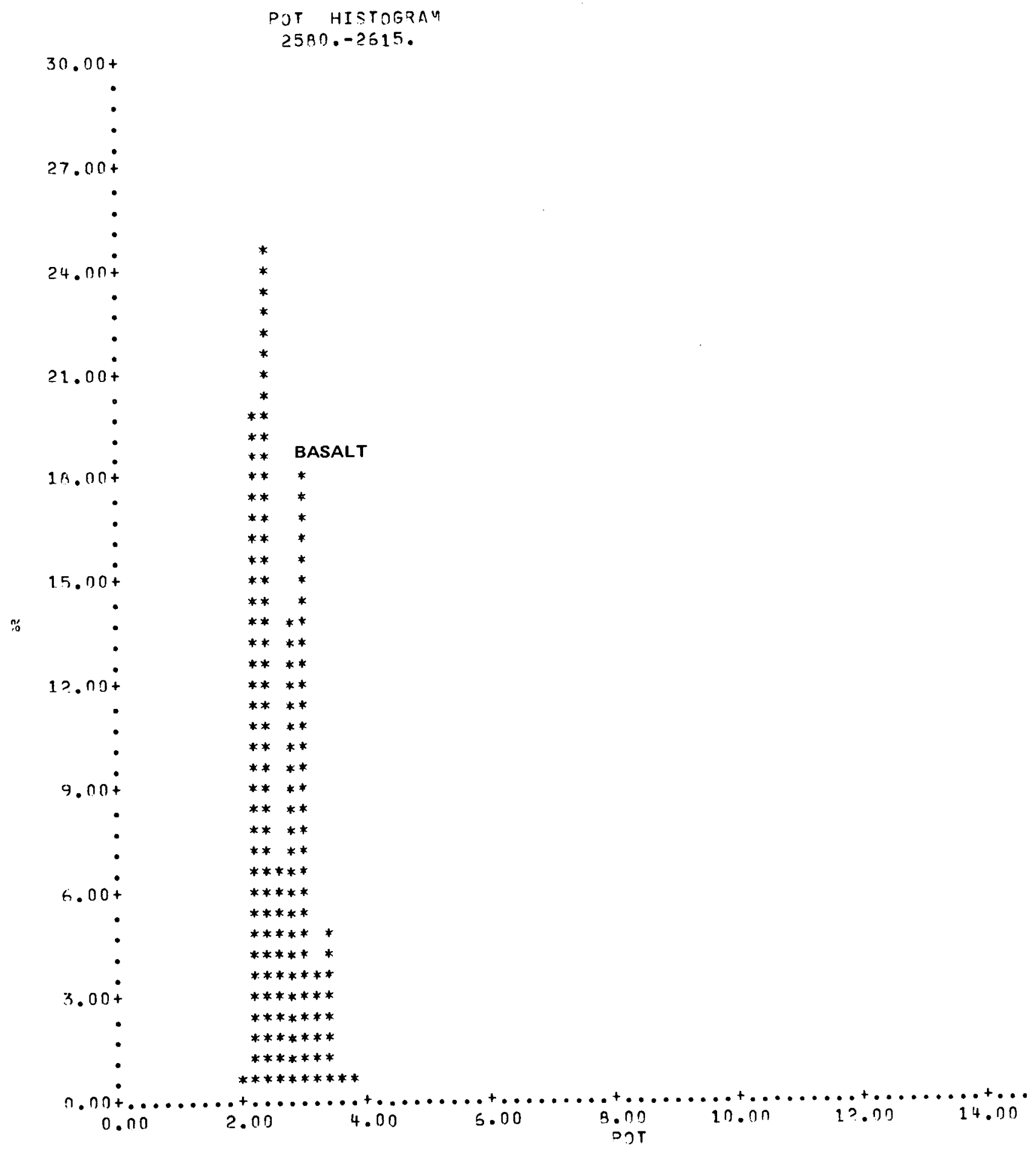

FIGURE 9. Potassium-40 Histogram 


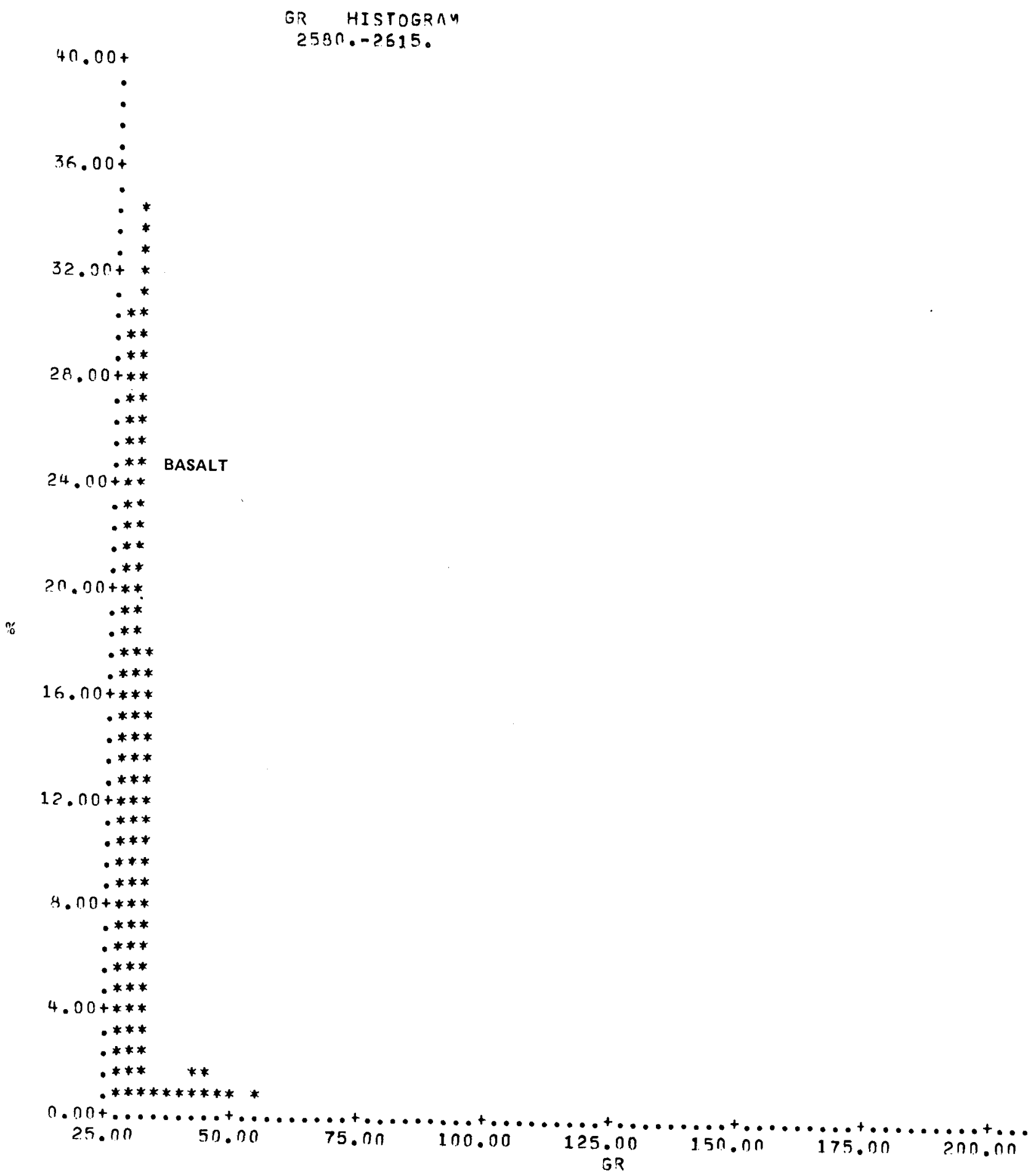

FIGURE 10. Gamma Ray Histogram 


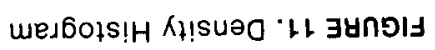

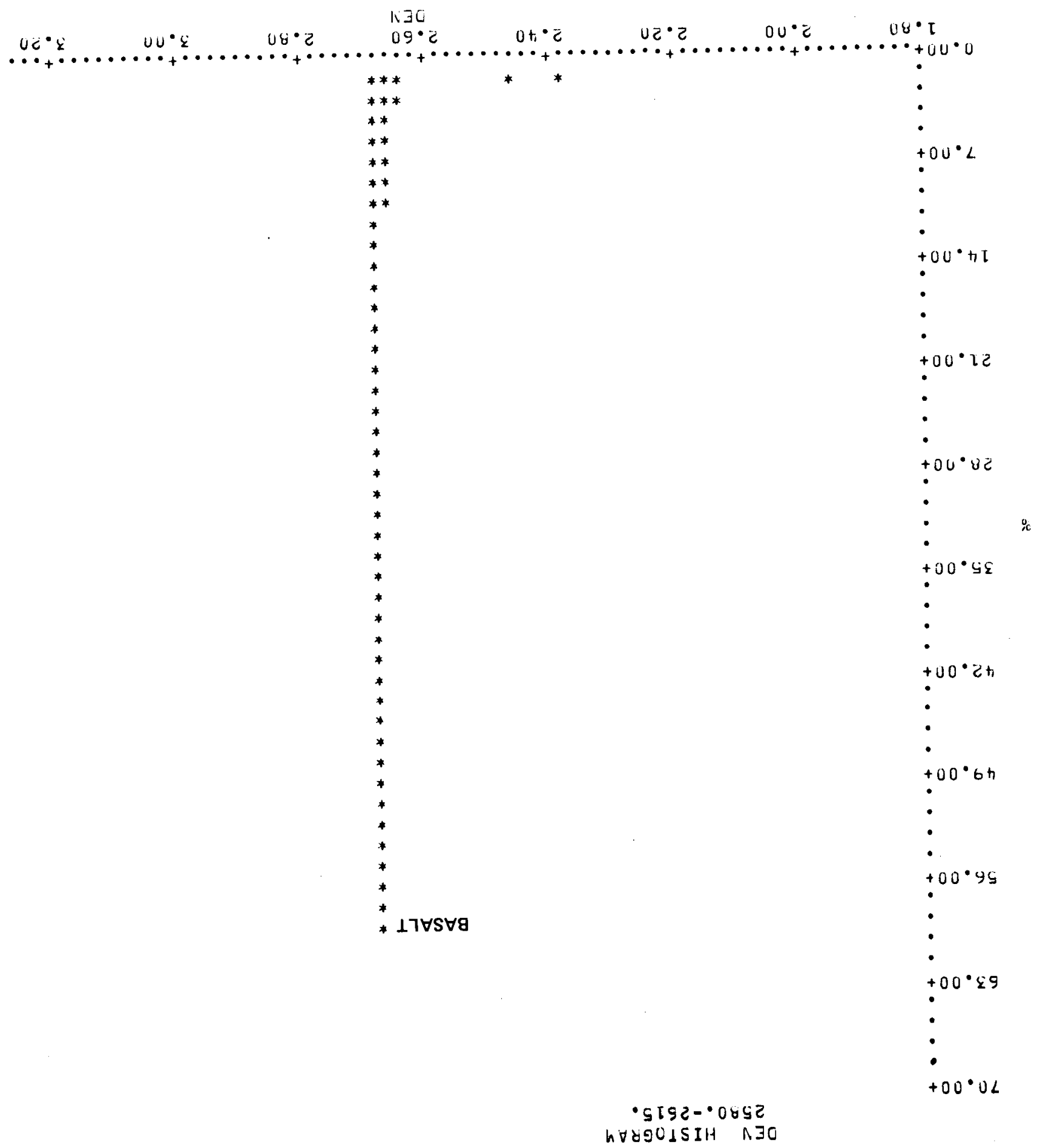




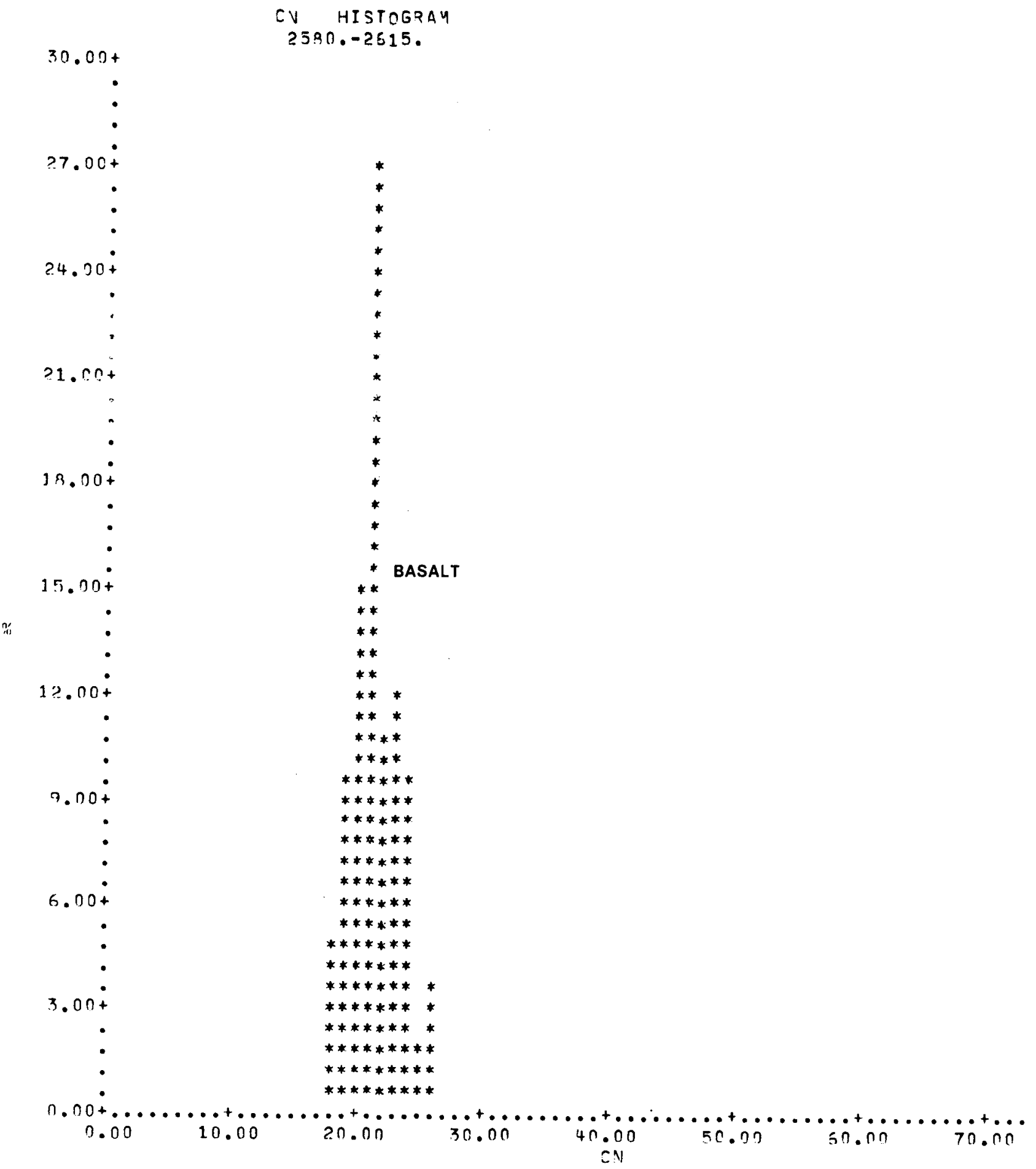

FIGURE 12. Compensated Neutron Histogram 


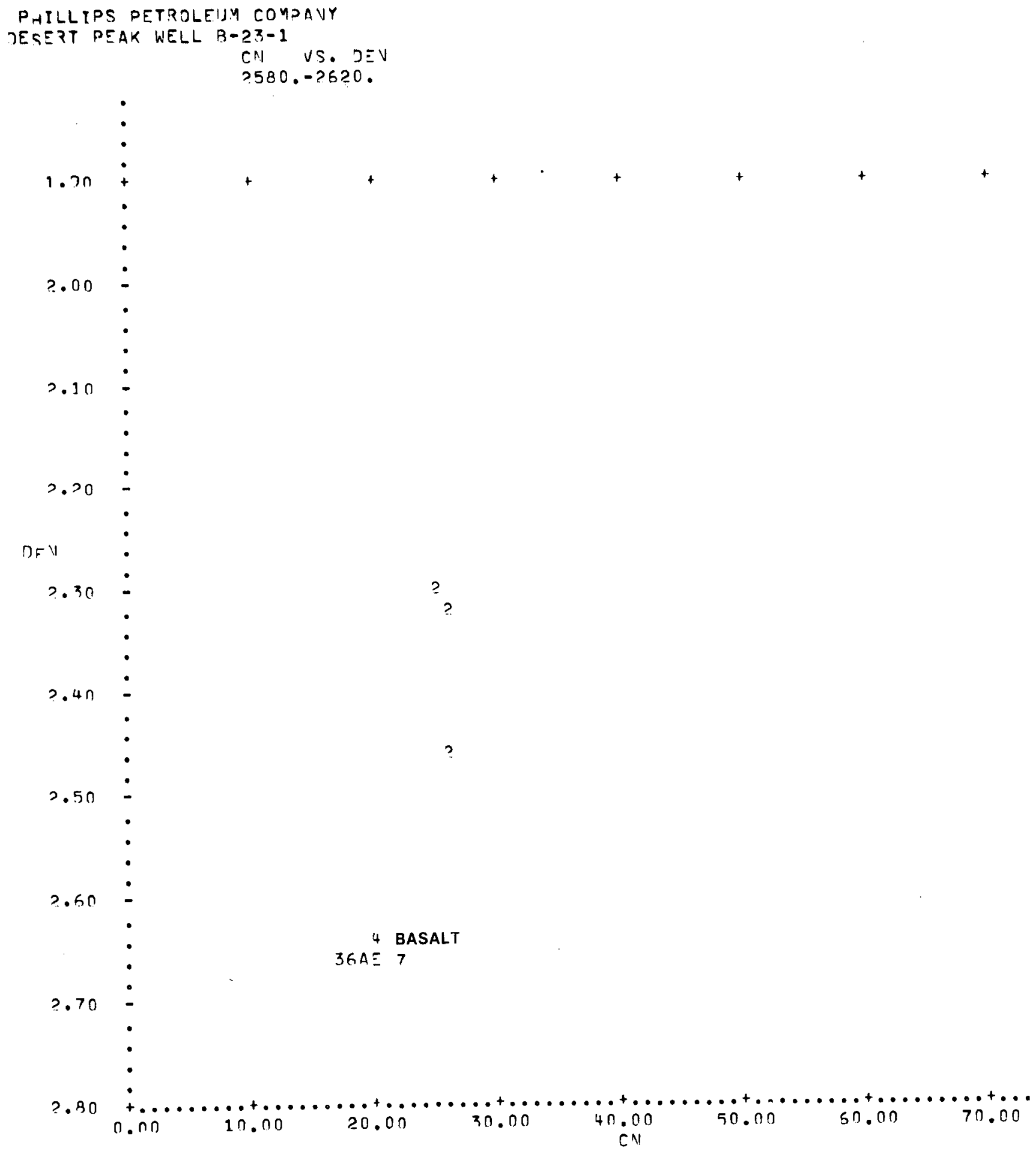

FIGURE 13. Crossplot of Density vs. Compensated Neutron porosity 
PHILLIPS PETROLFIJM COMPAVY

JESERT PEAK WELL $R-23-1$

$A C$ VS. DEV

2580.-?620.

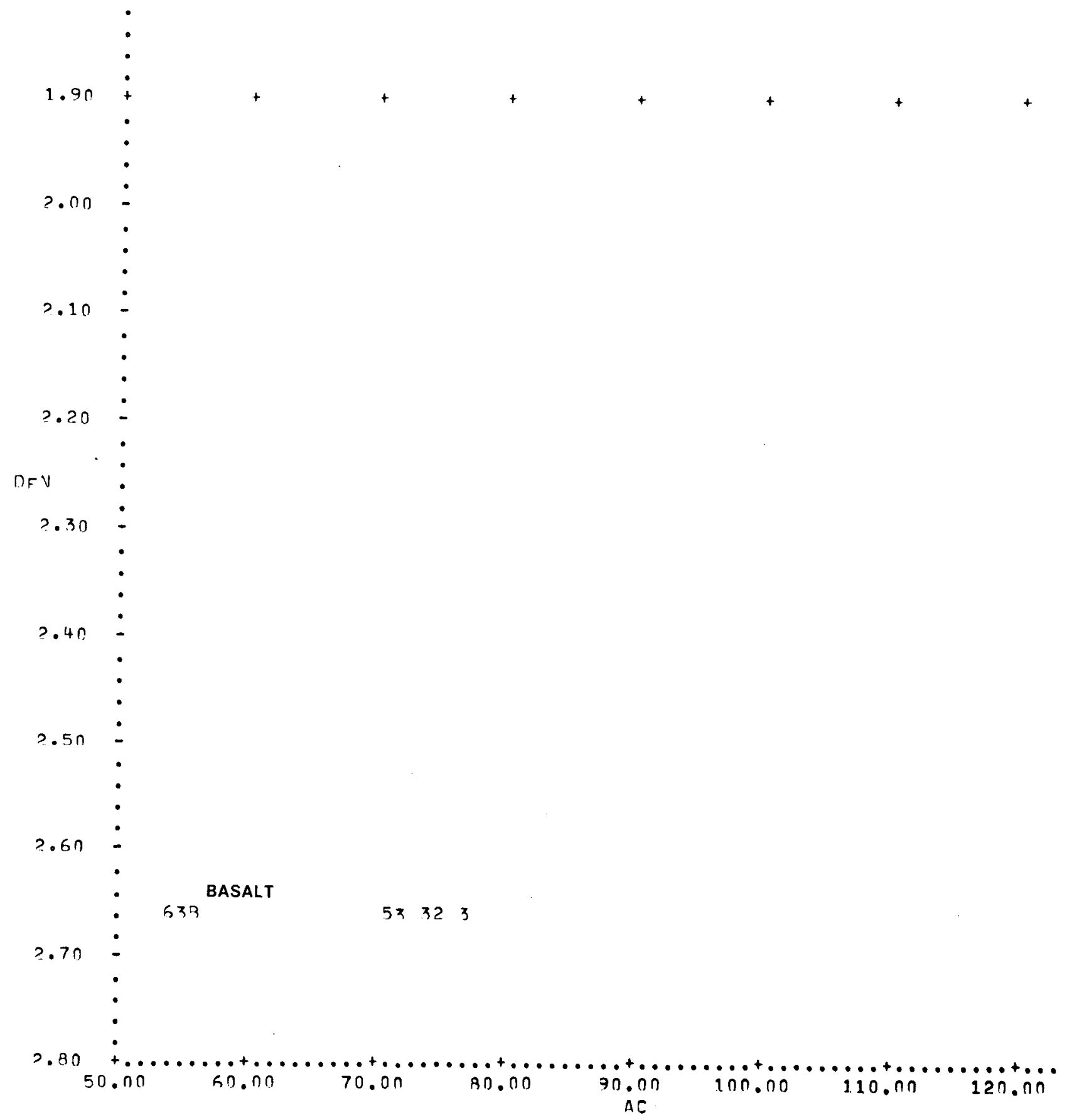

FIGURE 14. Crossplot of Density vs. specific Acoustic time 


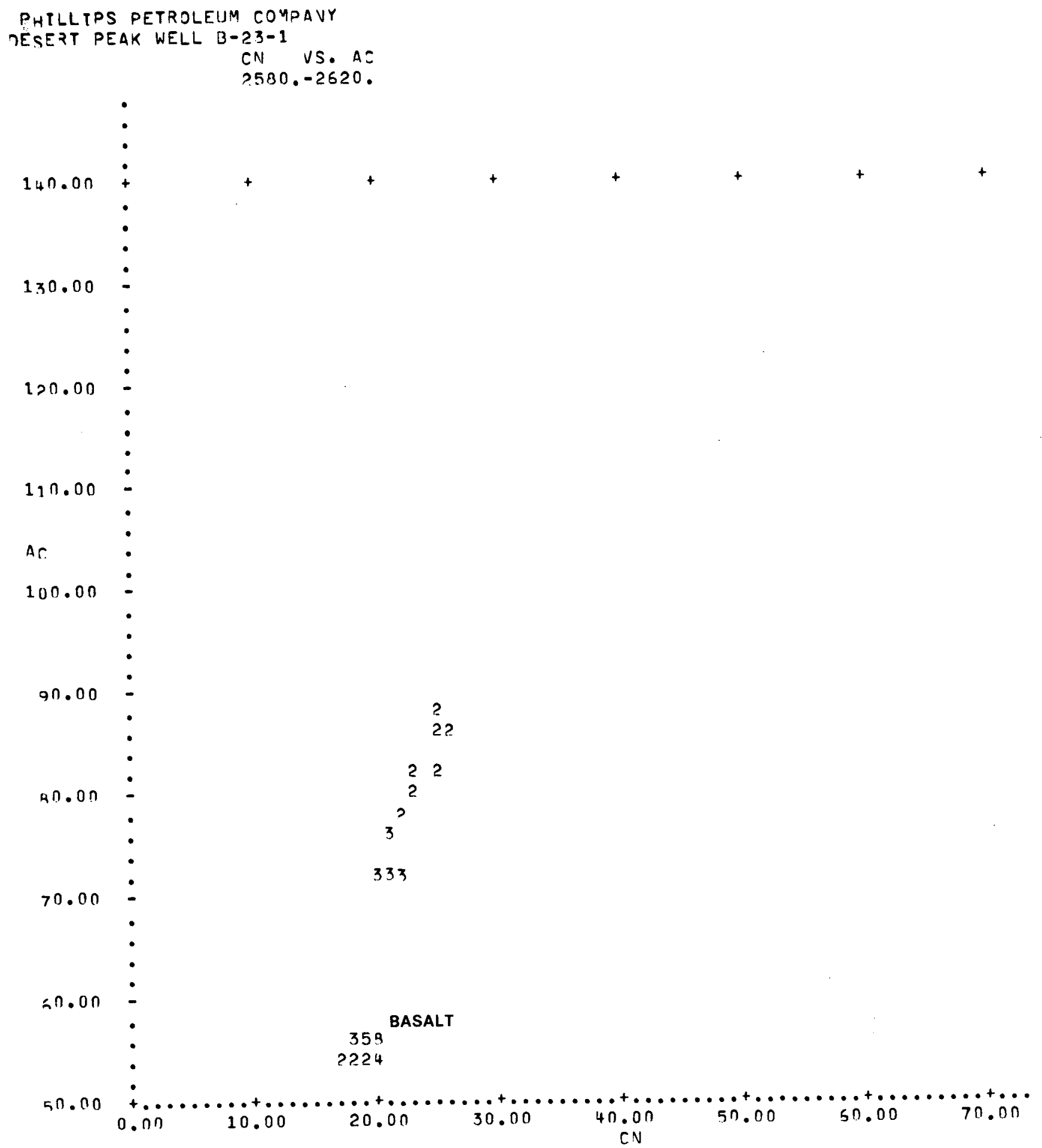

FIGURE 15. Crossplot of specific Acoustic time vs. Compensated Neutron porosity 


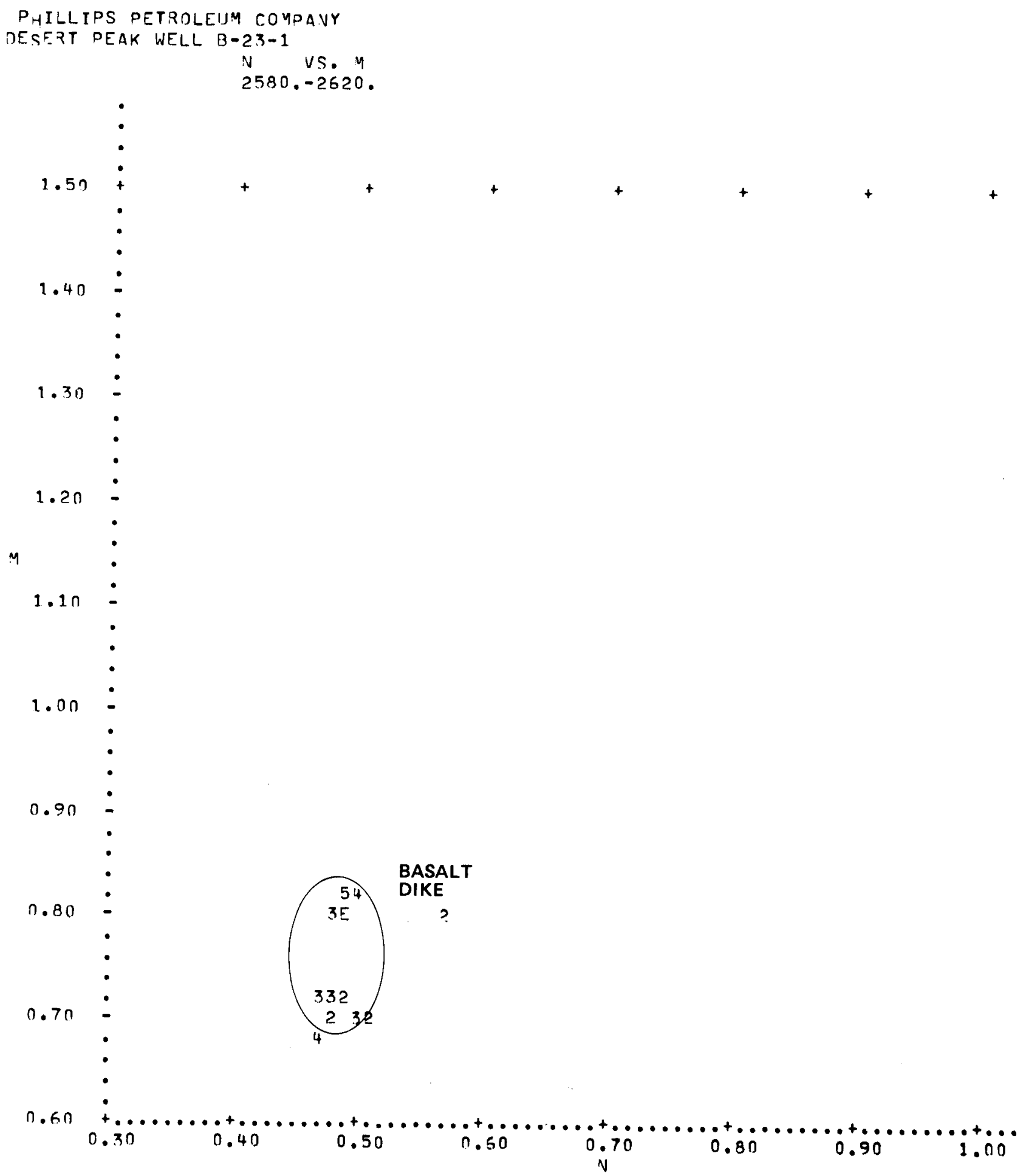

FIGURE 16. M - N PlOt 


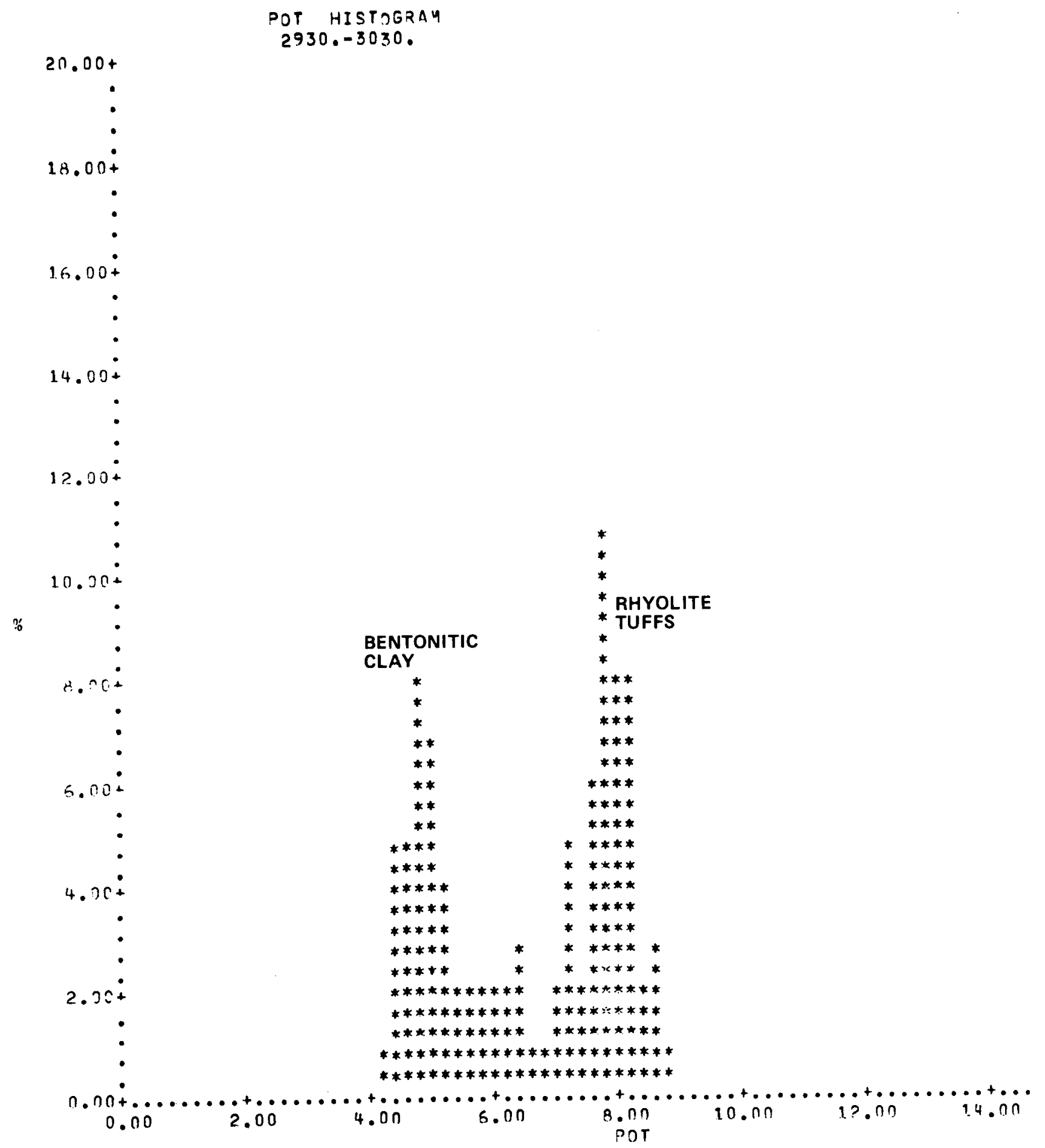

FIGURE 17. Potassium-40 Histogram 


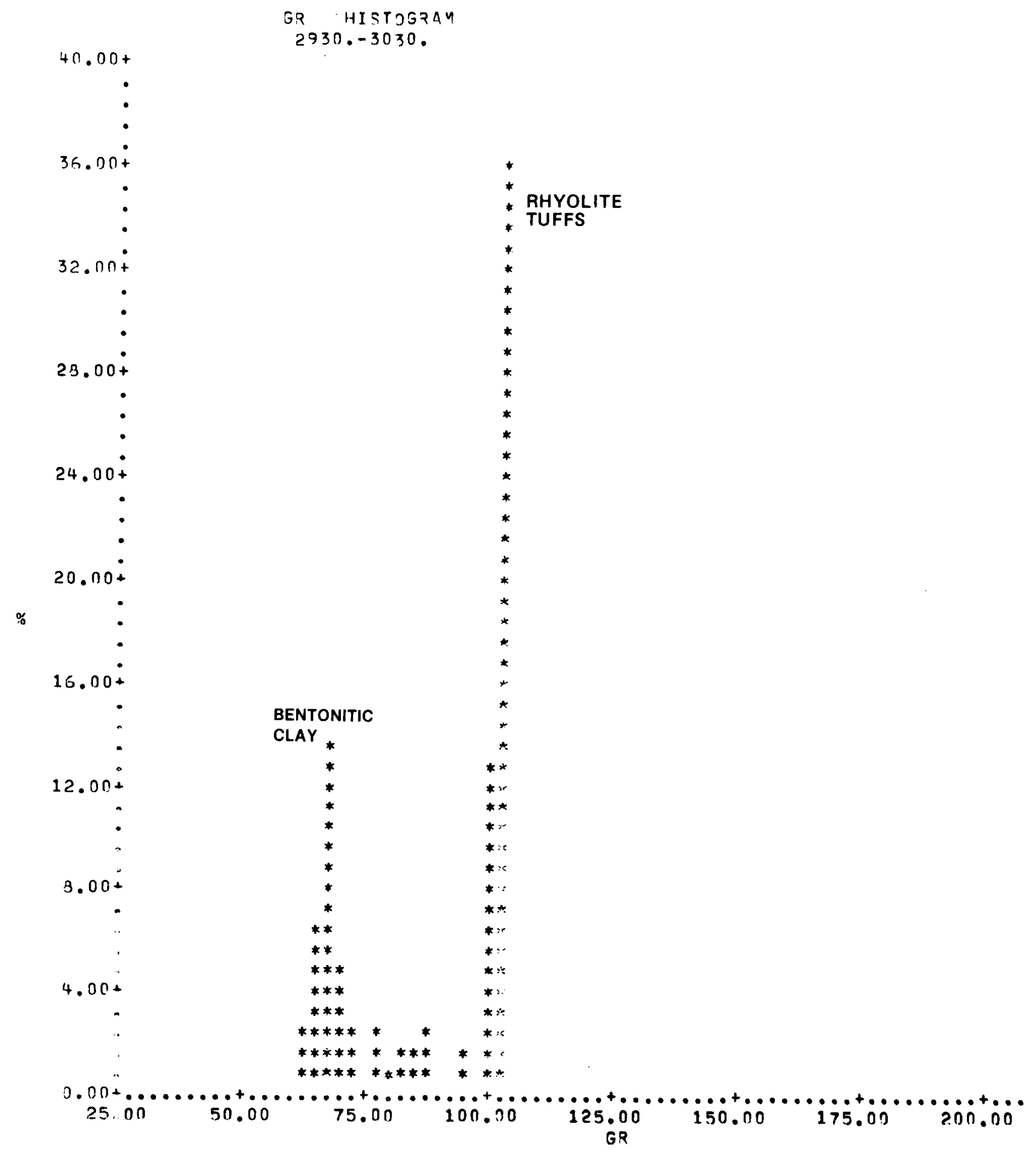

FIGURE 18. Gamma Ray Histogram 


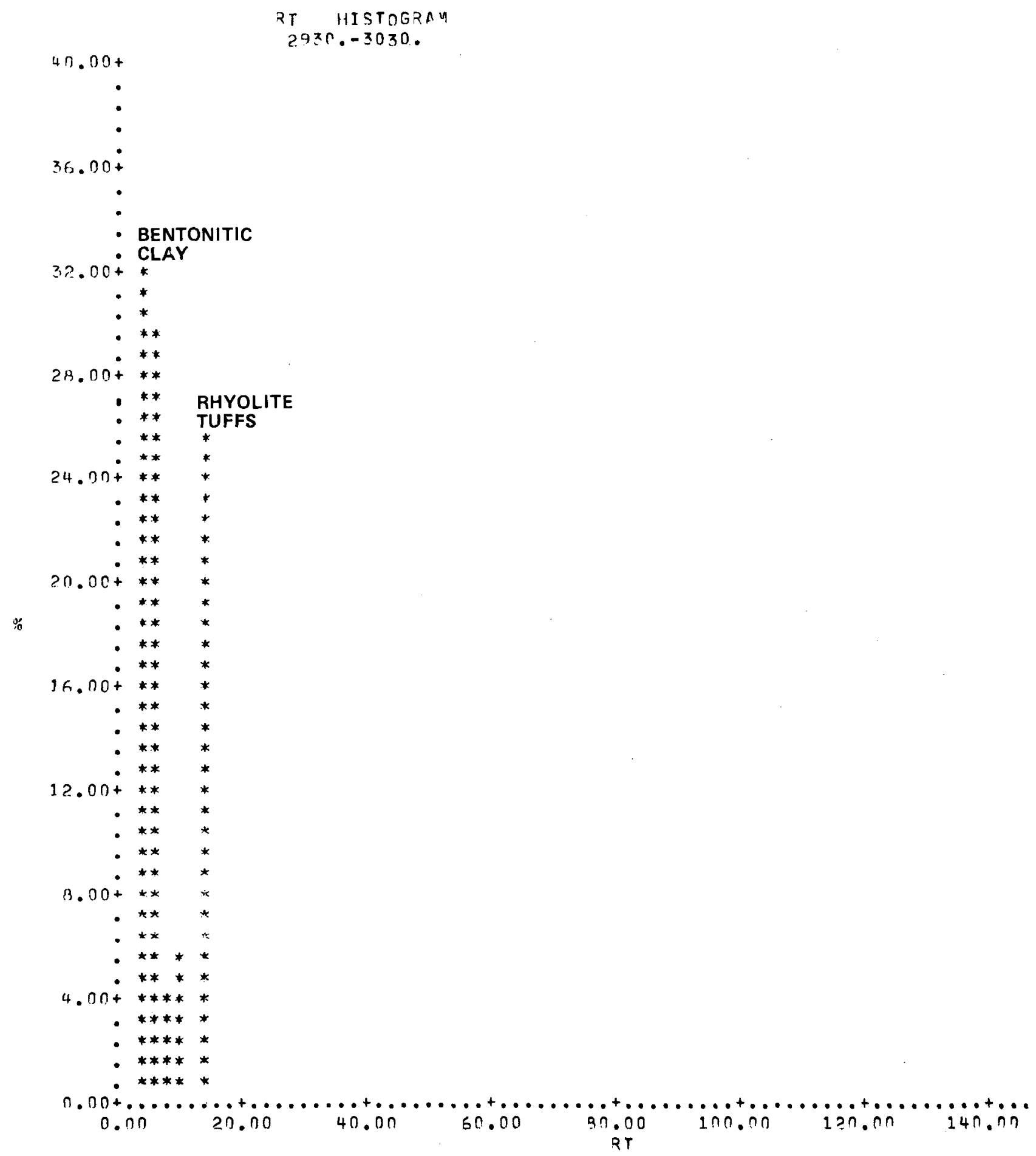

FIGURE 19. Resistivity Histogram 


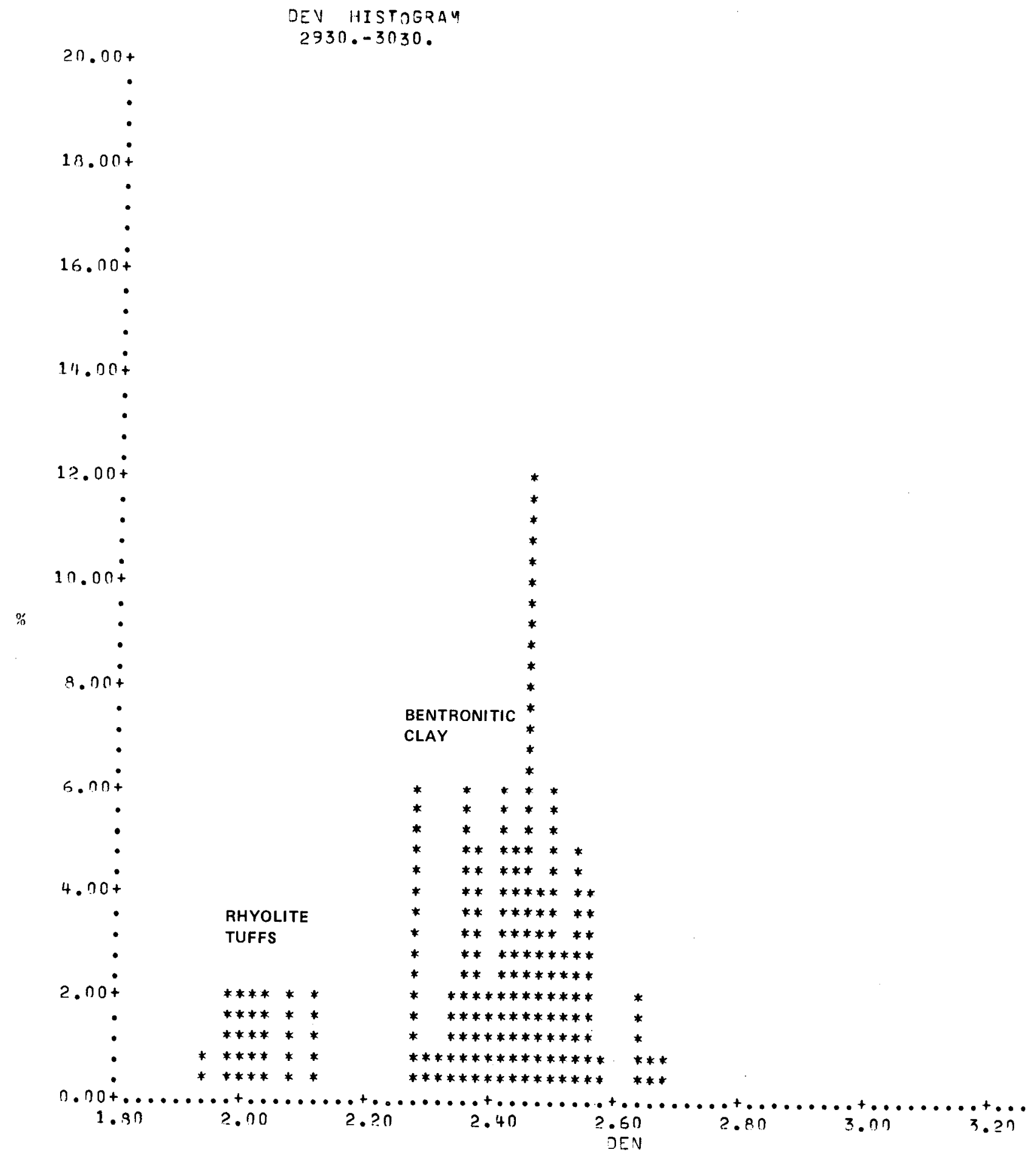

FIGURE 20. Density Histogram 


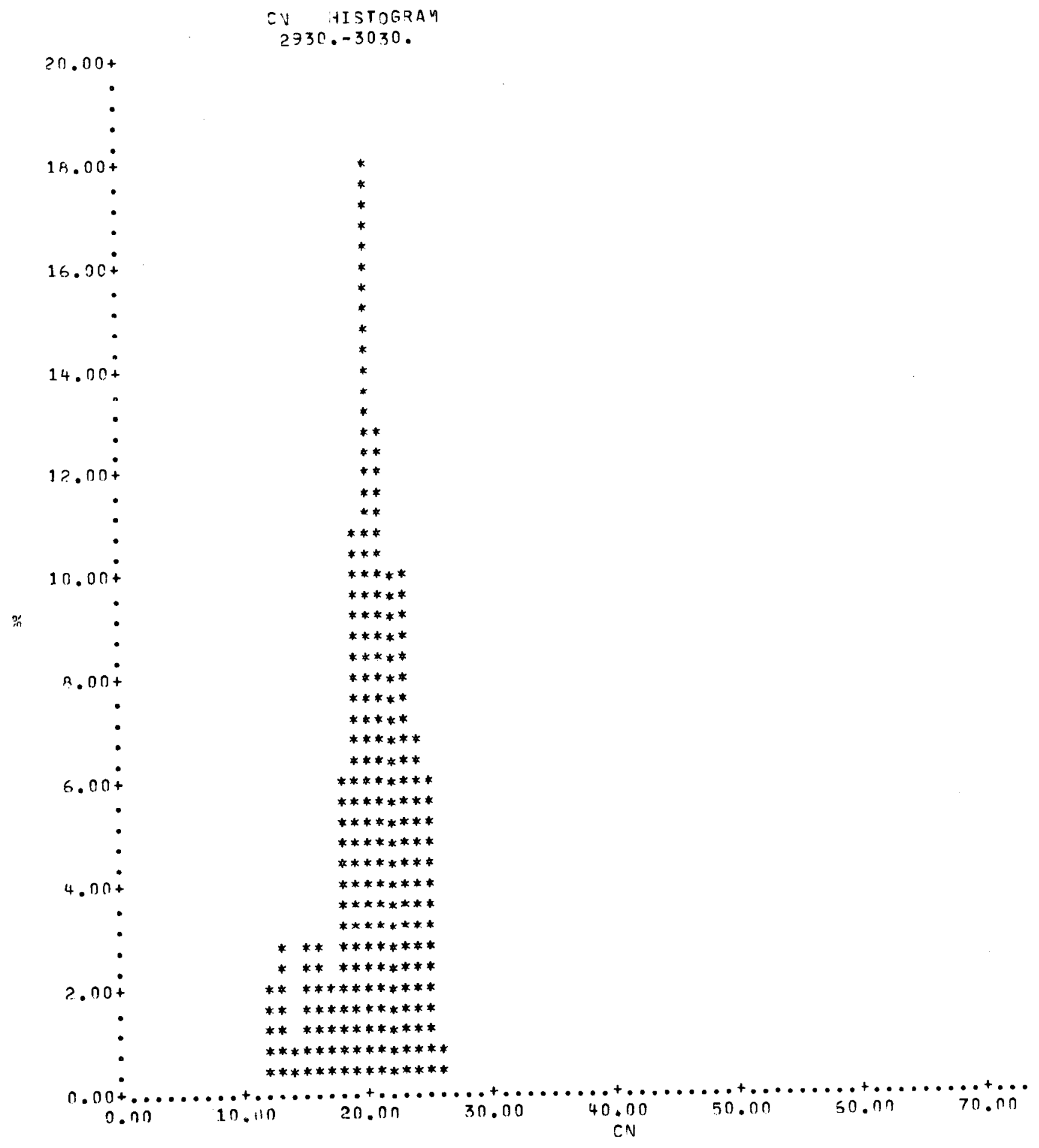

FIGURE 21. Compensated Neutron Histogram 


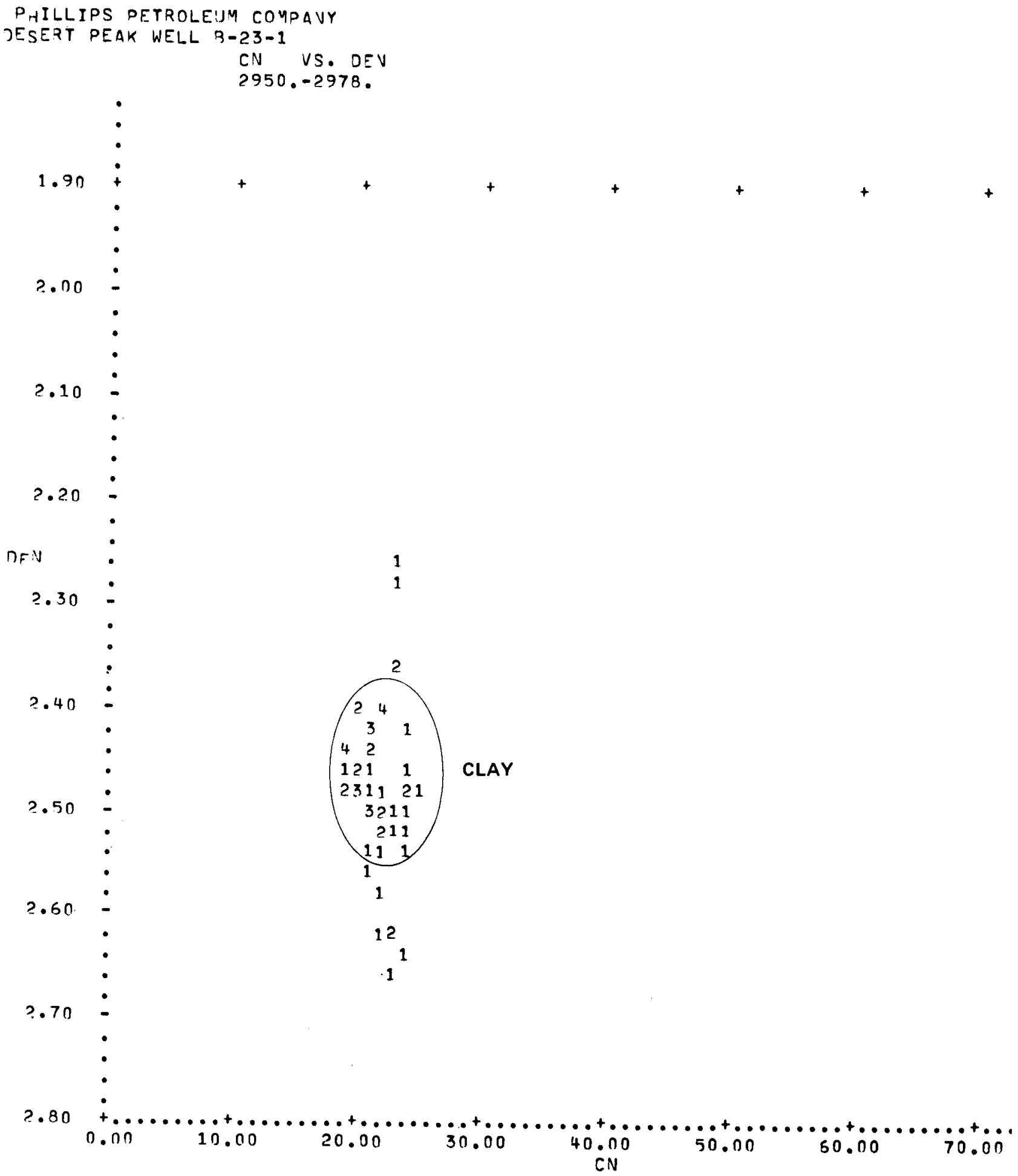

FIGURE 22. Crossplot of Density vs. Compensated Neutron porosity 


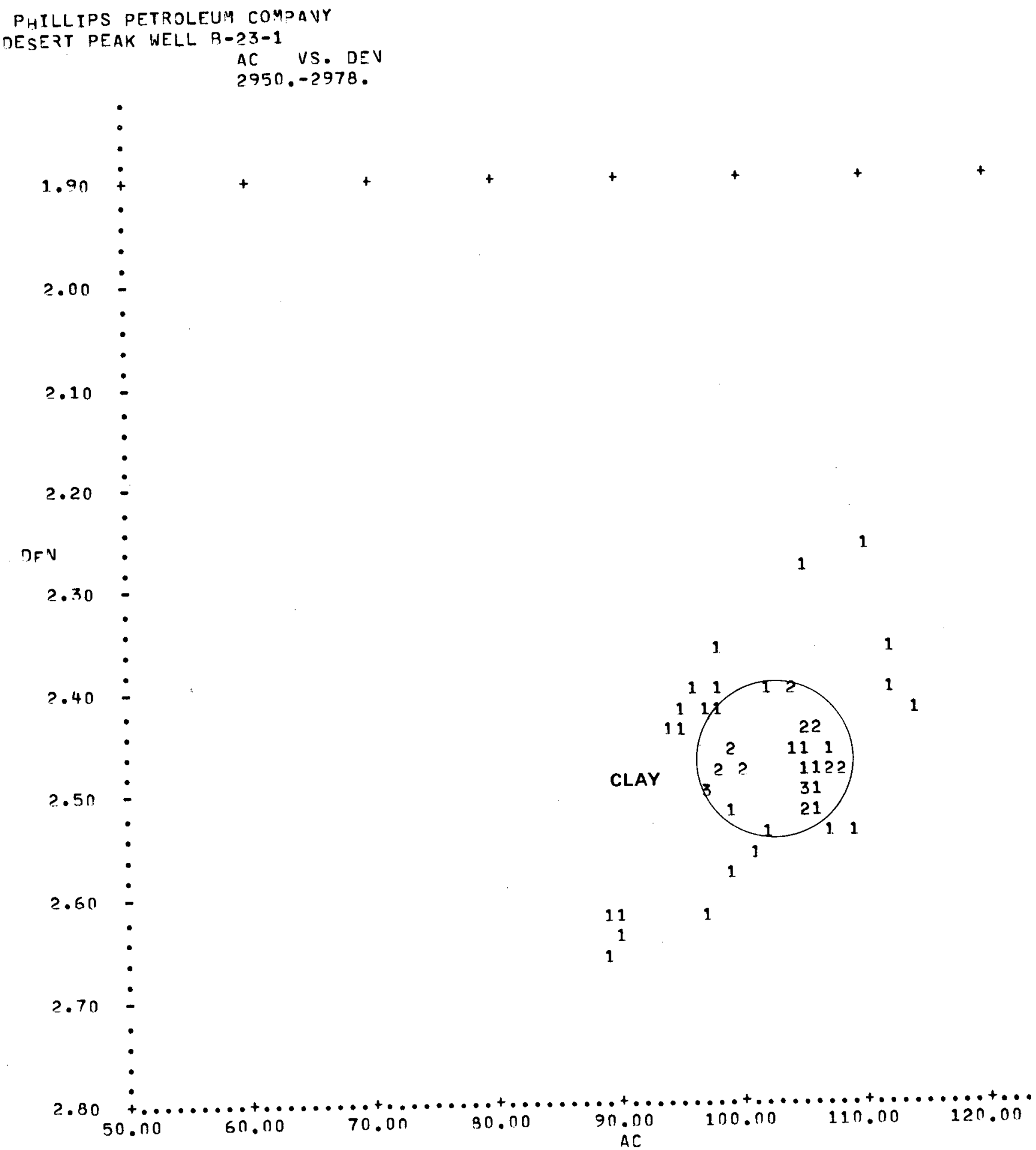

FIGURE 23. Crossplot of specific Acoustic time vs. Density 
PHTLLTPS PETROLEUM COMPAVY

TES

CN VS. AE

$2950 .-2.979$.

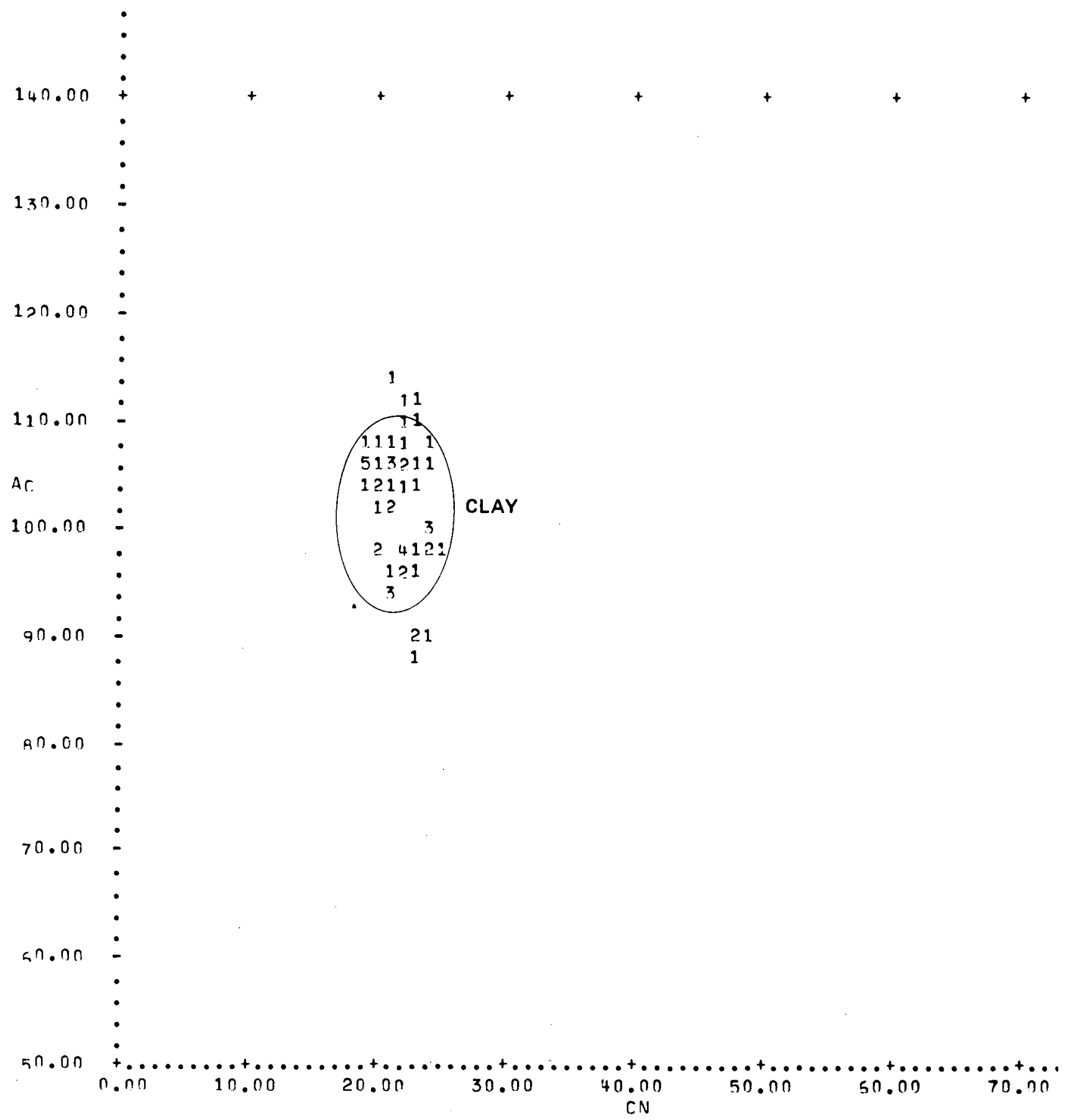

FIGURE 24. Crossplot of Compensated Neutron porosity vs. specific Acoustic time 


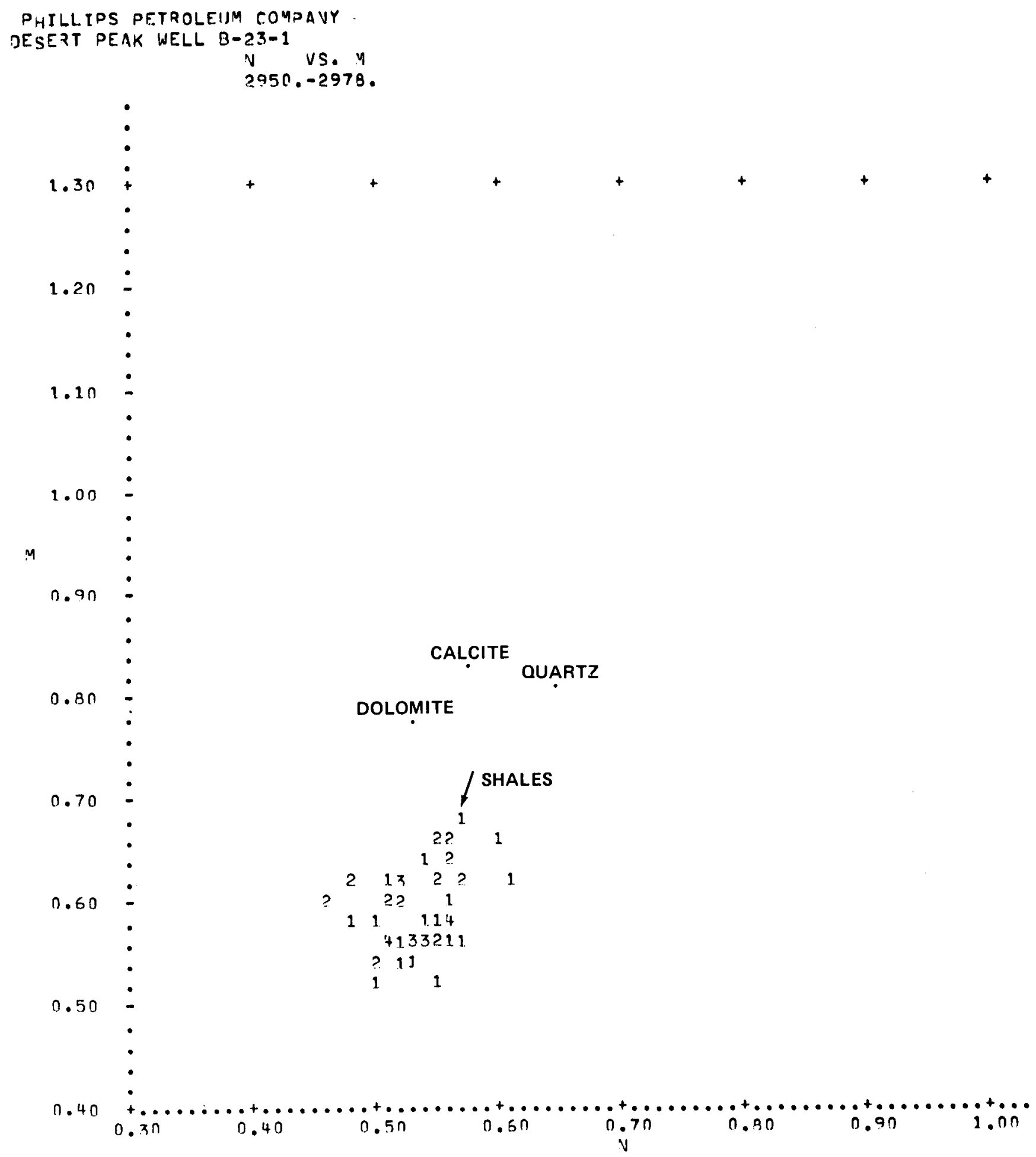

FIGURE 25. $\mathrm{M} \cdot \mathrm{N}$ Plot 


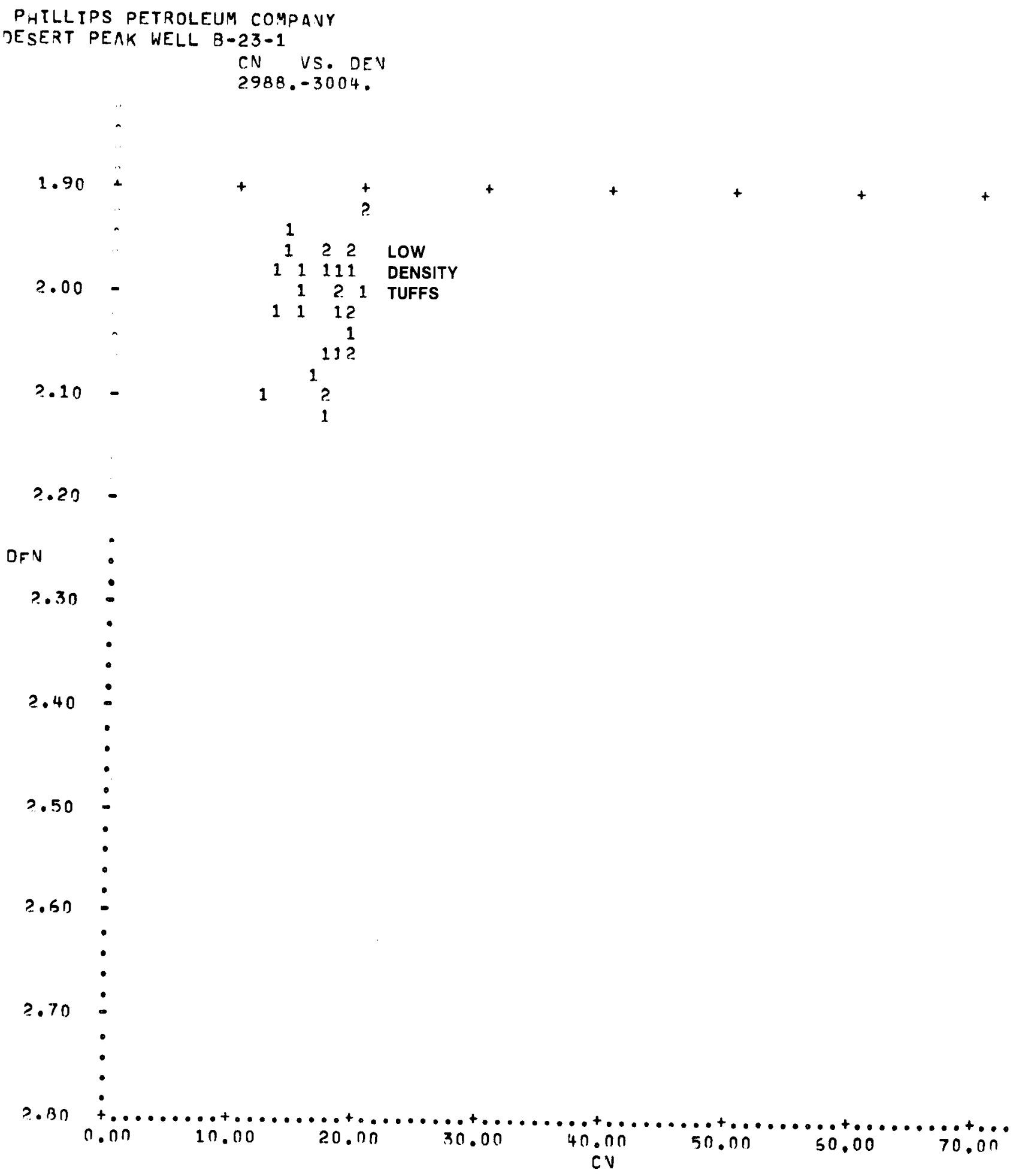

FIGURE 26. Crossplot of Density vs. Compensated Neutron porosity 


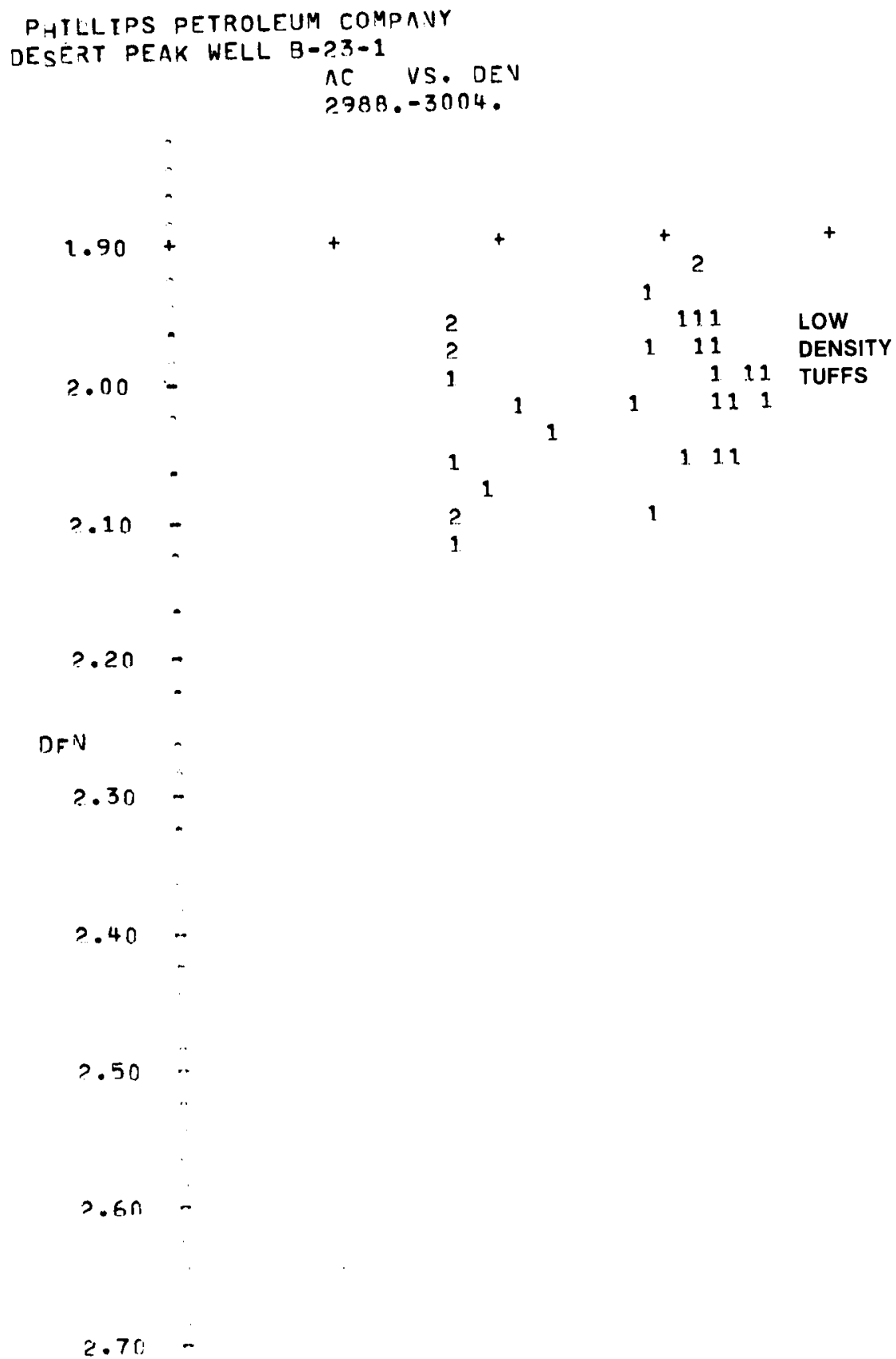

2.70 
PHILLIPS PETROLE!JM COMPANY

DESERT PEAK WELL B-23-1

$C N$ VS. AC

$2988 .-3004$.

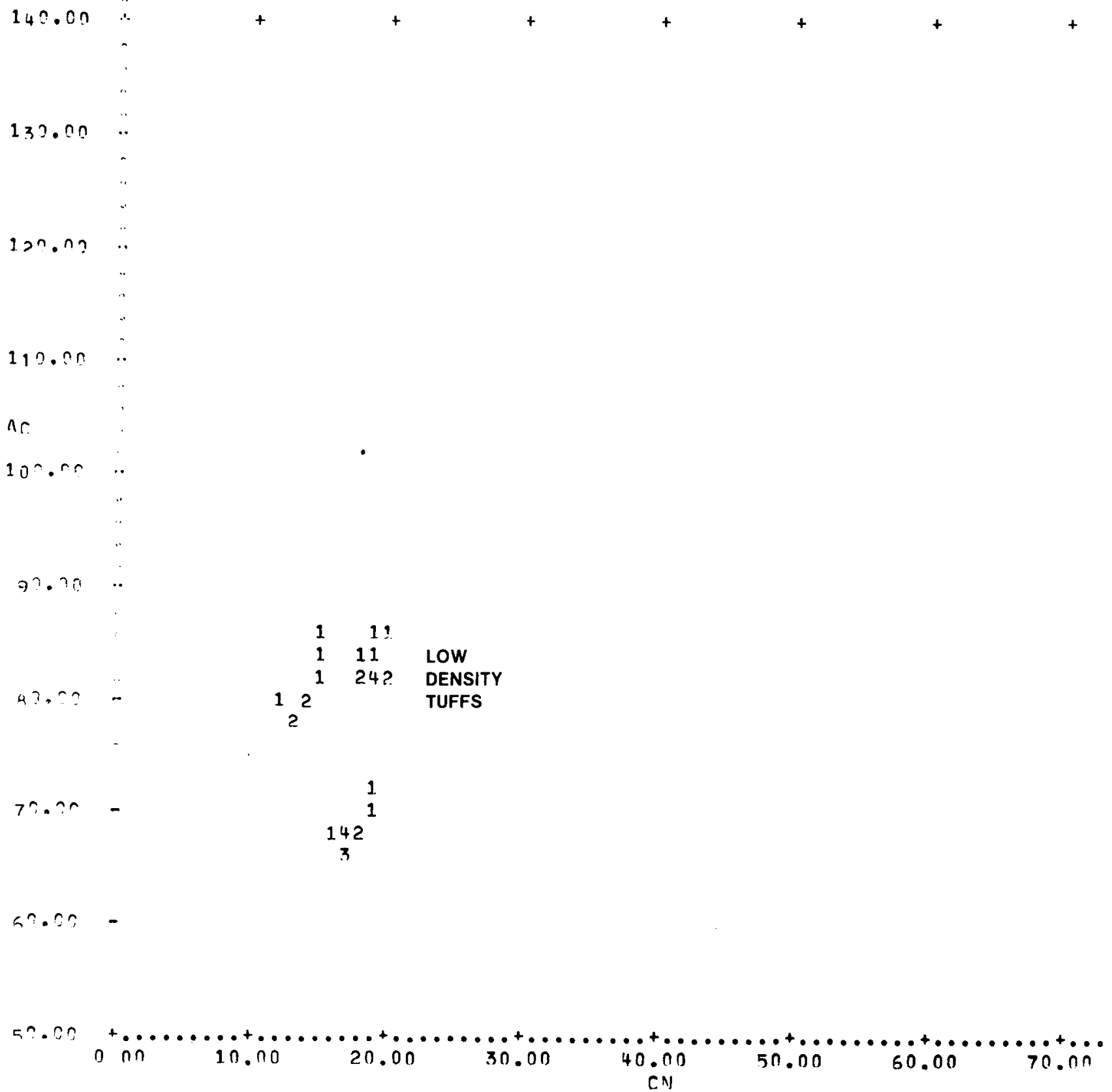

FIGURE 28. Crossplot of Compensated Neutron porosity vs. specific Acoustic time 
PHILLIPS PETROLEUM COMPANY

DESERT PEAK WELL B-23-1

$$
N \text { VS. M }
$$

$2988 .-3004$.

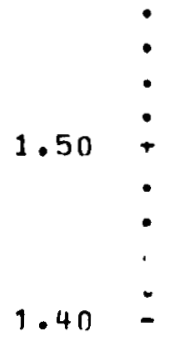

1.30$$
1.20=
$$

M

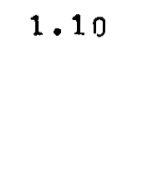

$$
\text { 1. } n \text { n }
$$

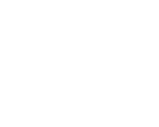

$0.9 n$

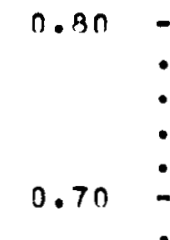

0.60
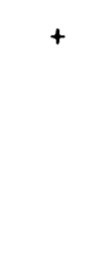


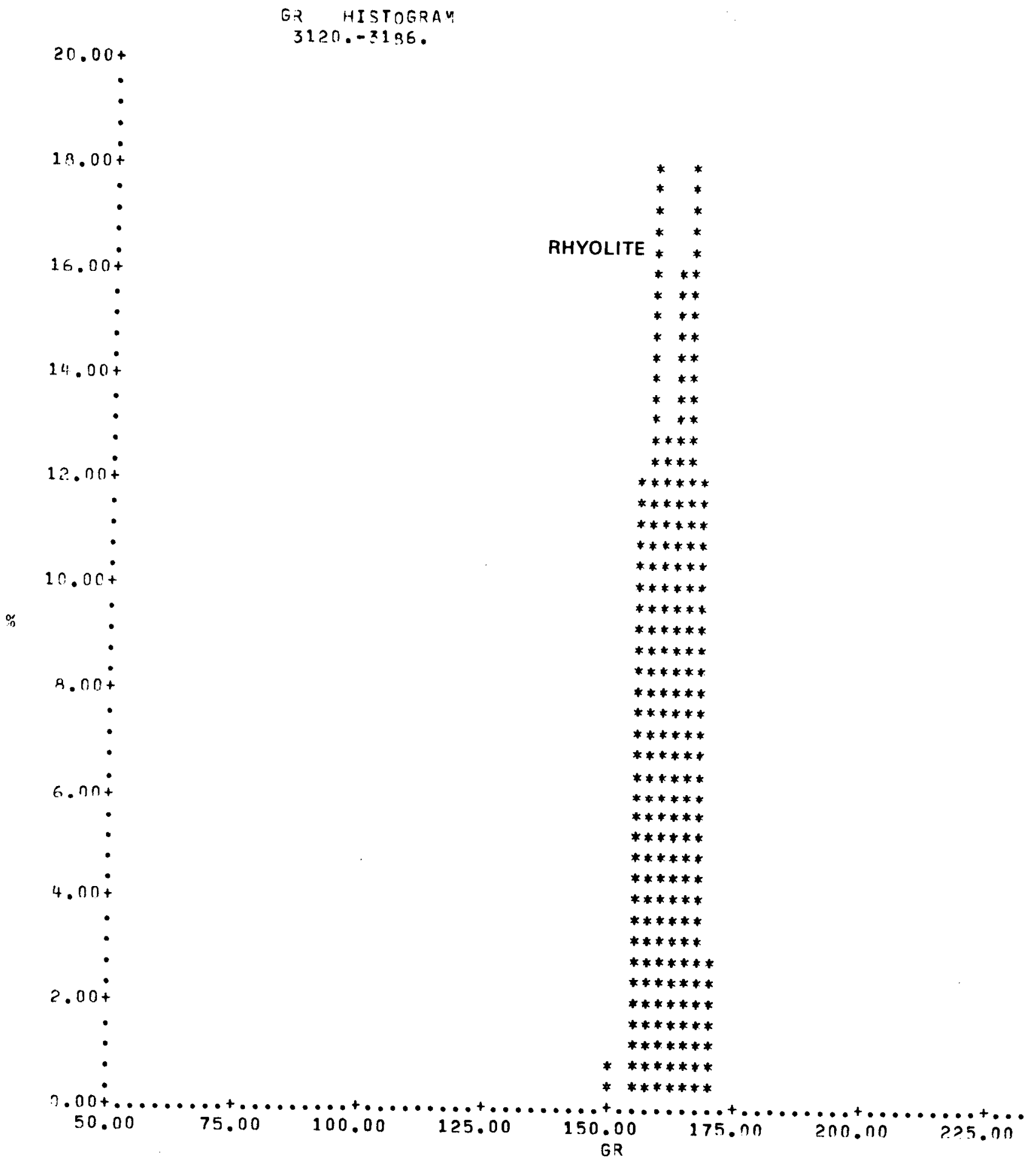

FIGURE 30. Gamma Ray Histogram 


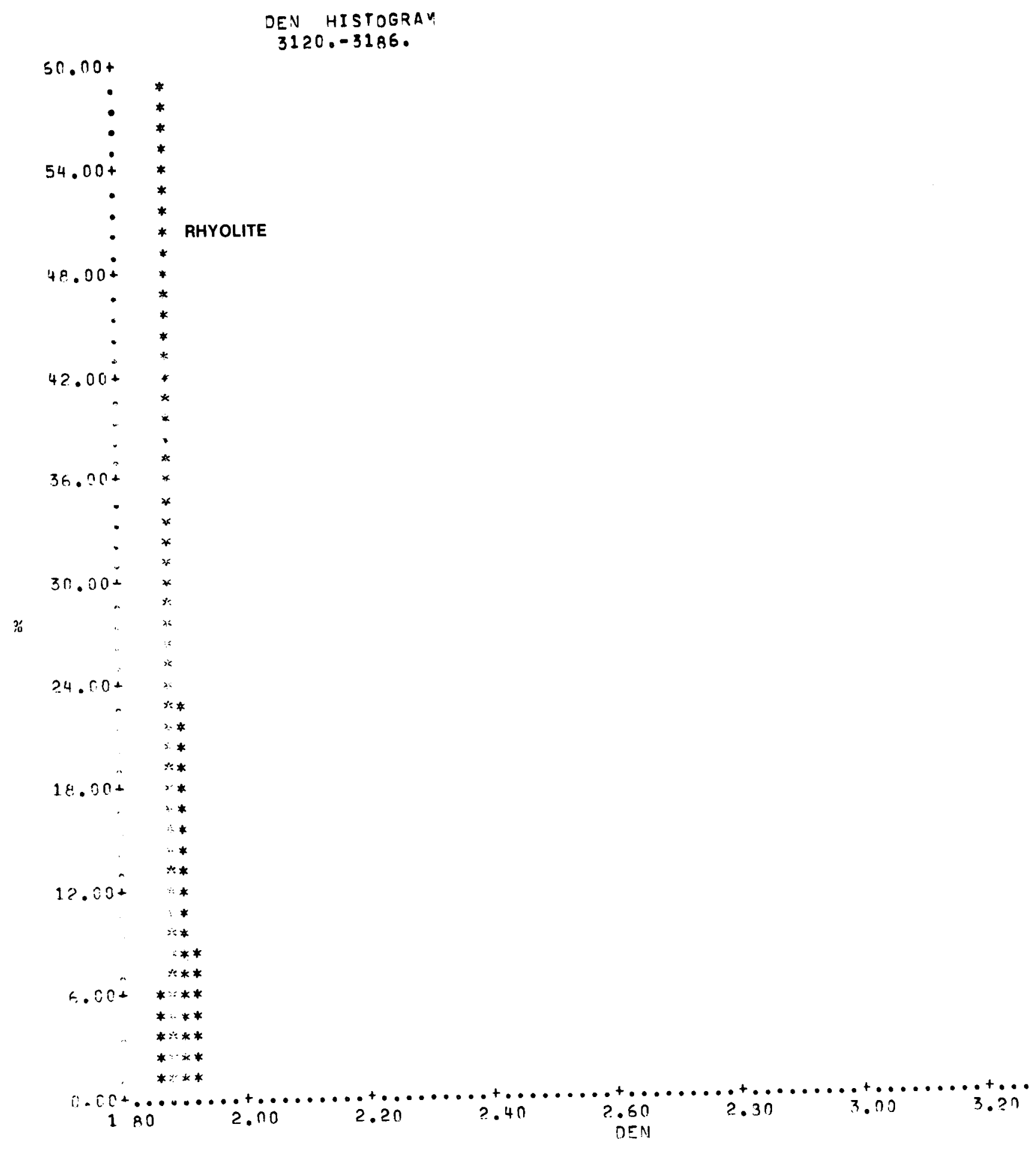

FIGURE 31. Density Histogram 


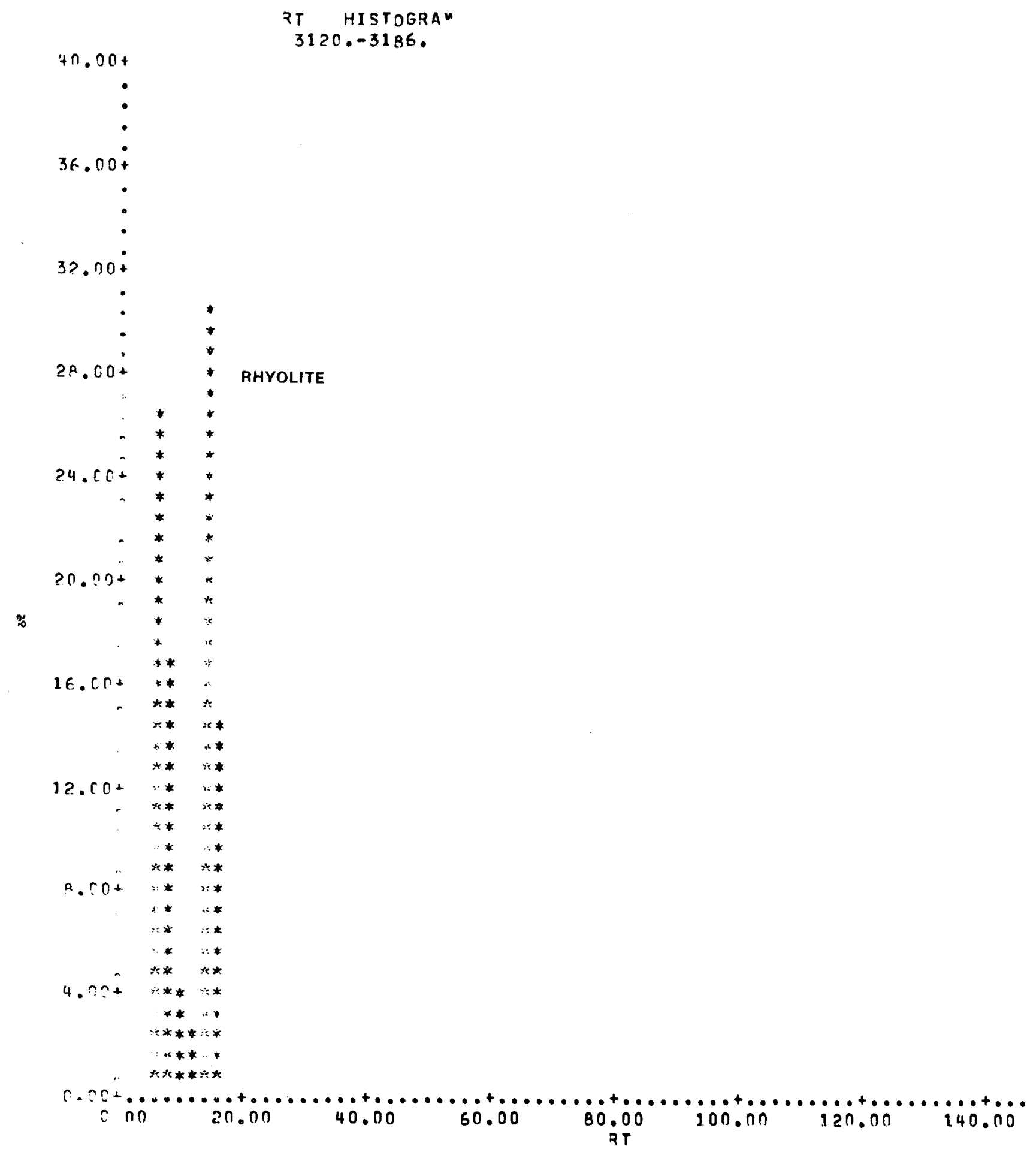

FIGURE 32. Resistivity Histogram 


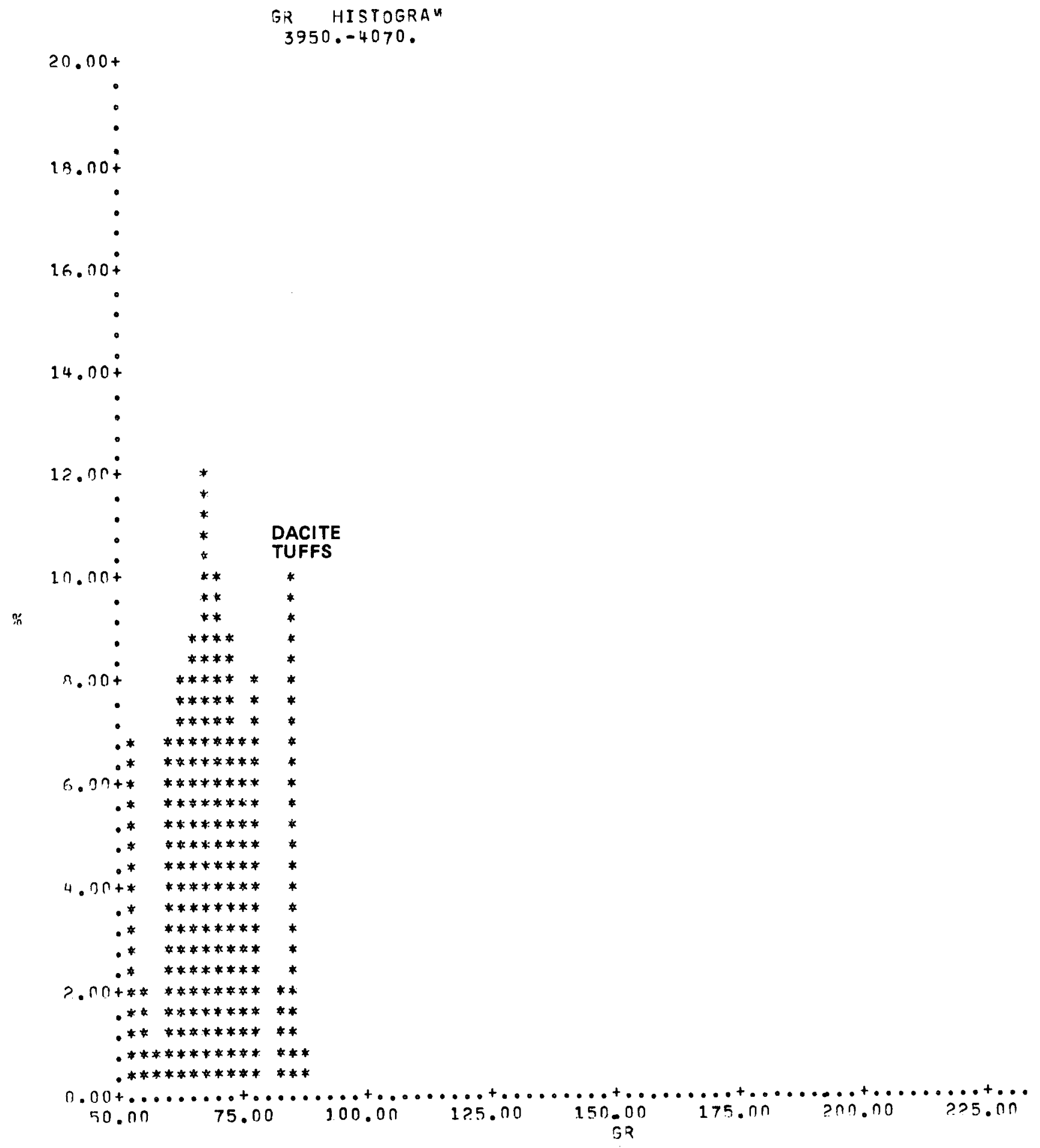

FIGURE 33. Gamma Ray Histogram 


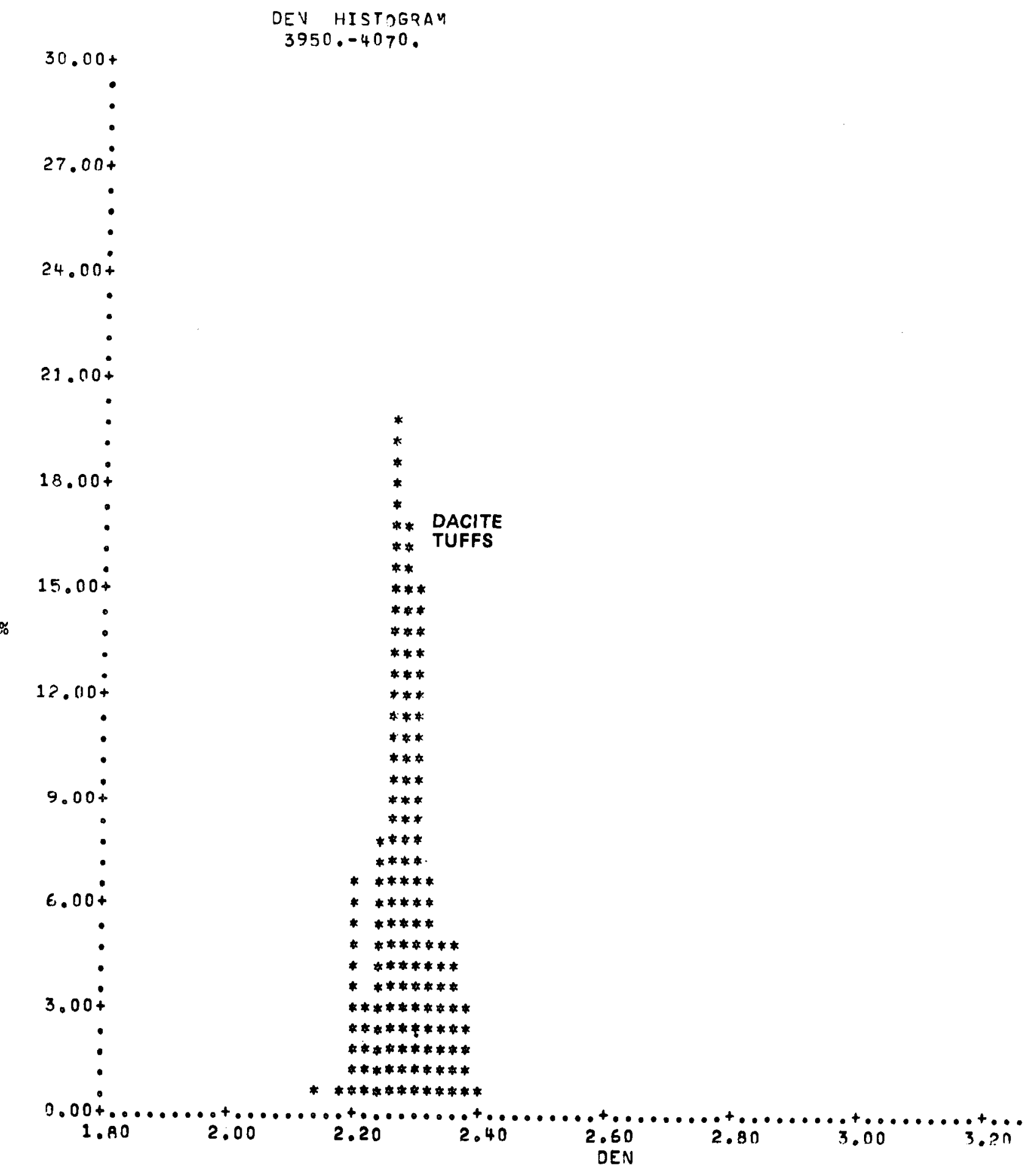

FIQURE 34. Density Histogram 


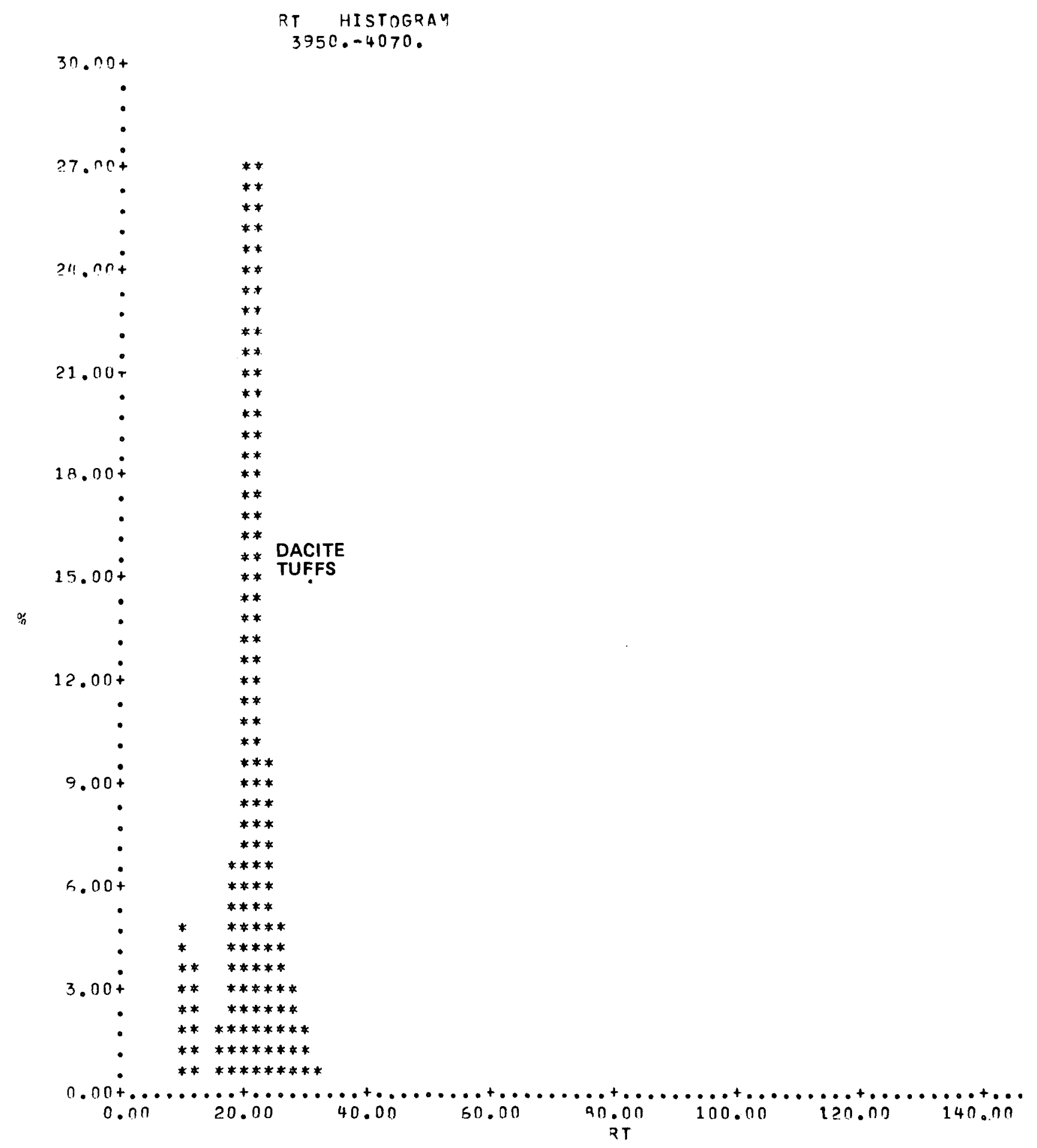

FIGURE 35. Resistivity Histogram 


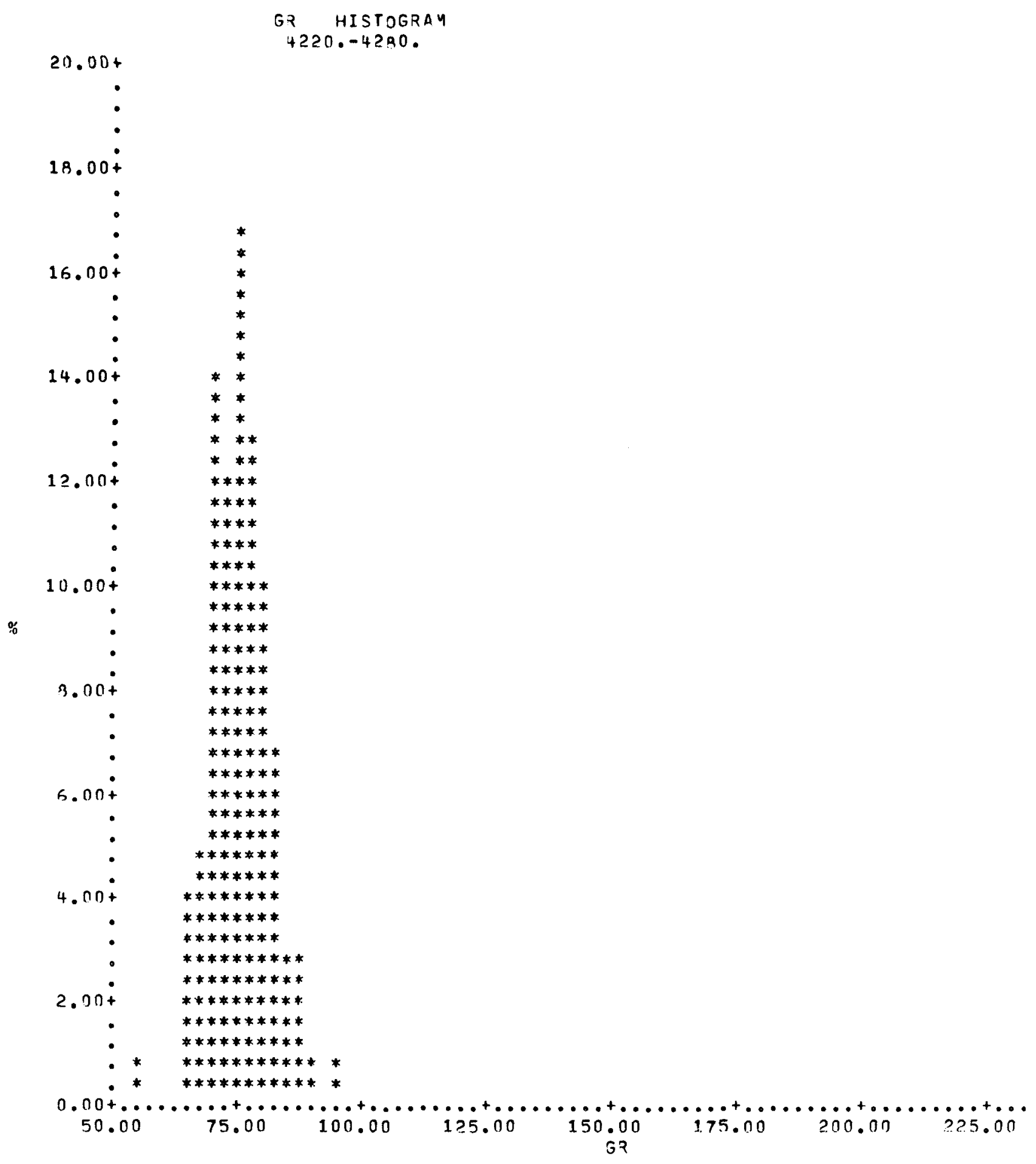

FIGURE 36. Gamma Ray Histogram 


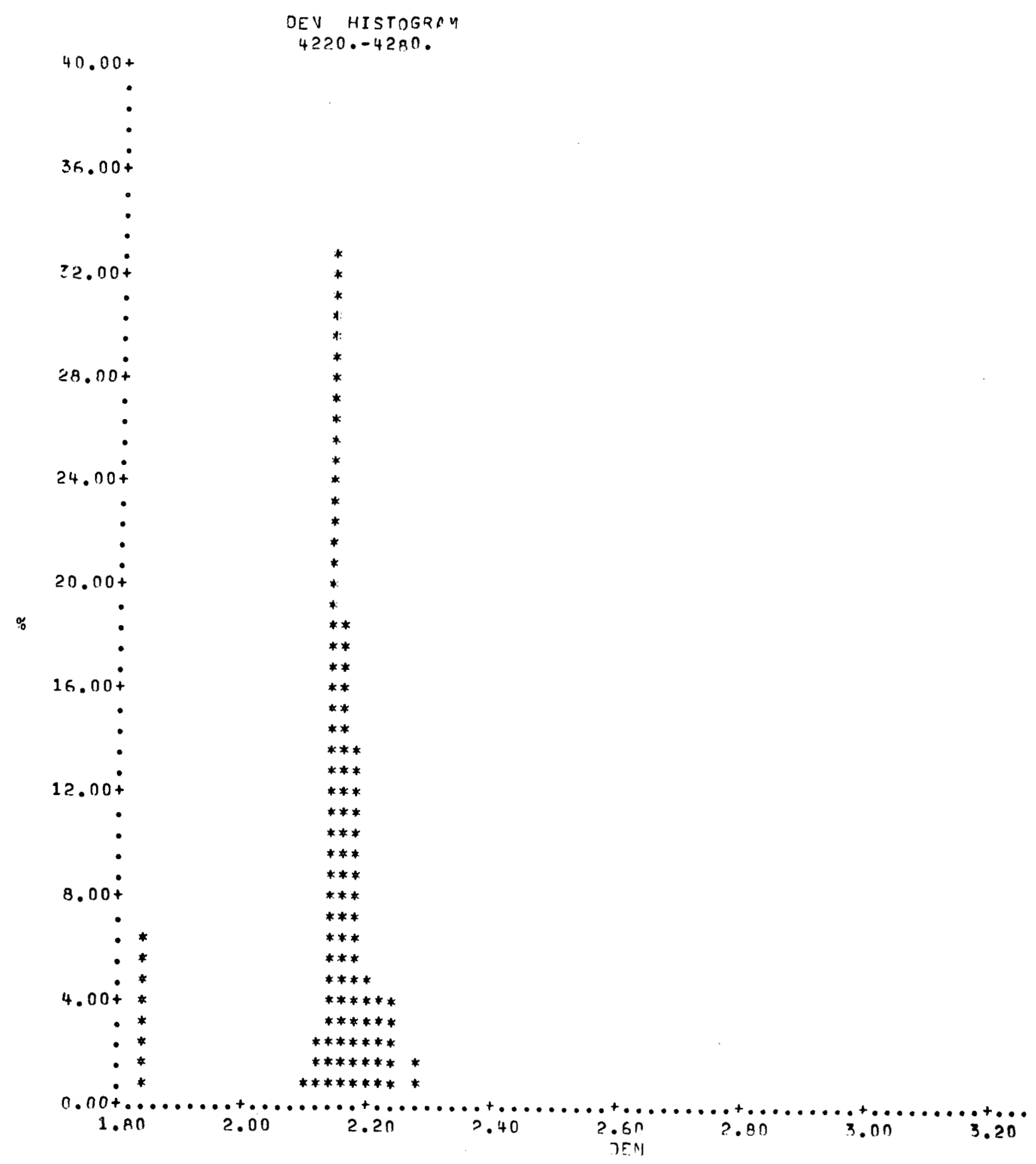

F1GURE 37. Density Histogram 


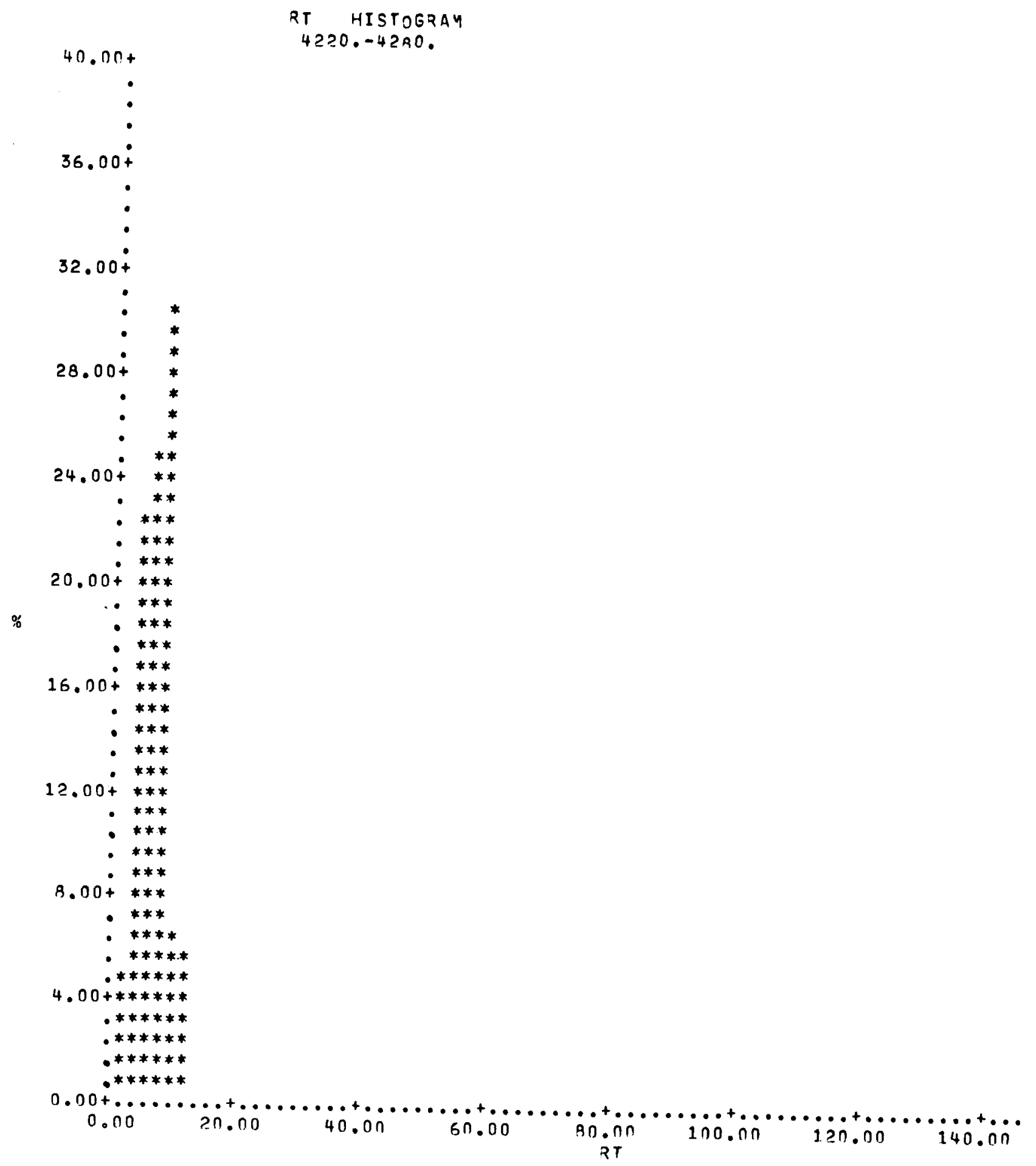

FIGURE 38. Resistivity Histogram 


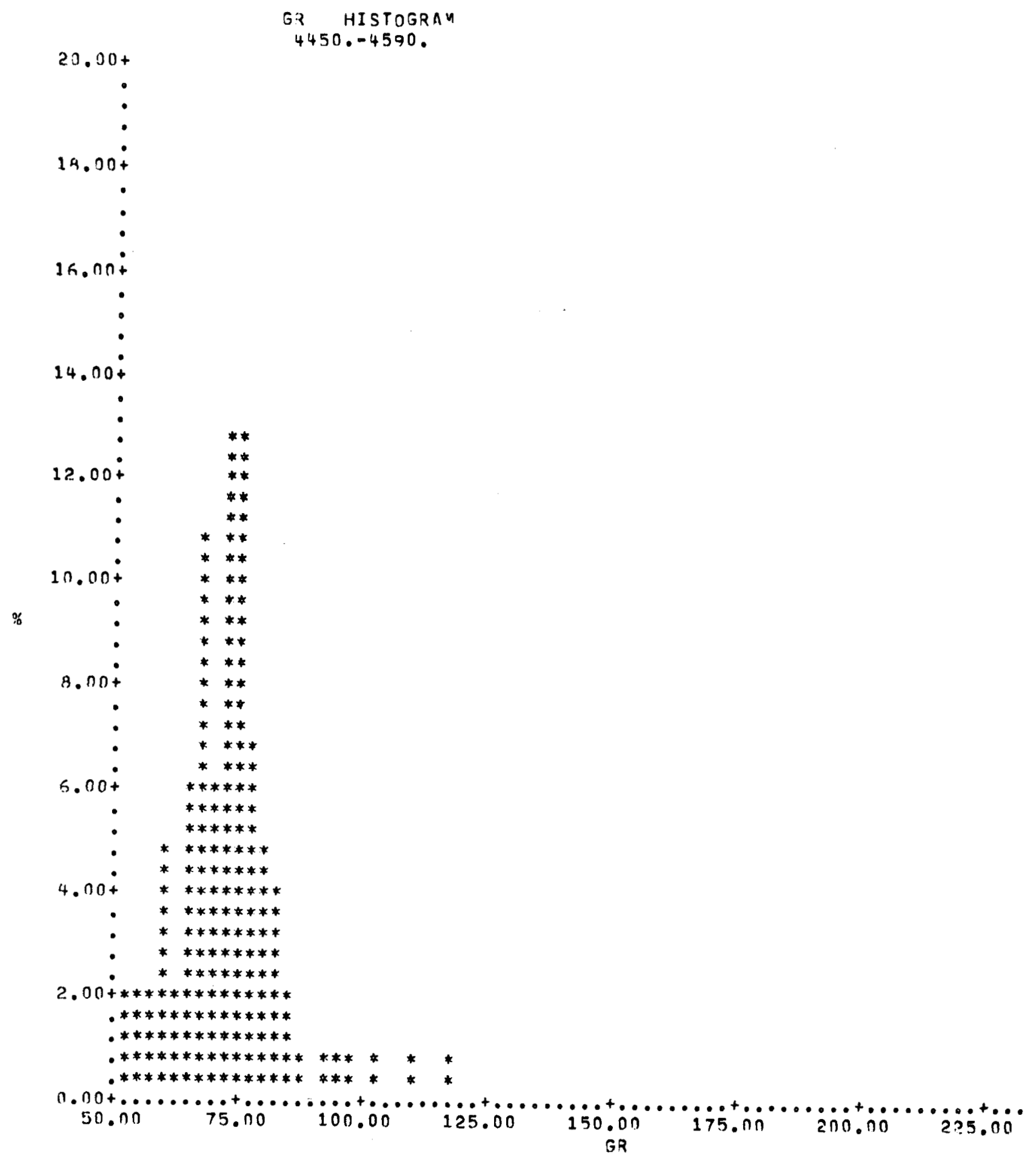

FIQURE 38. Gamma Ray Histogram 
DEV HISTOGRAY

$20.00+$ $4450 .-4590$.

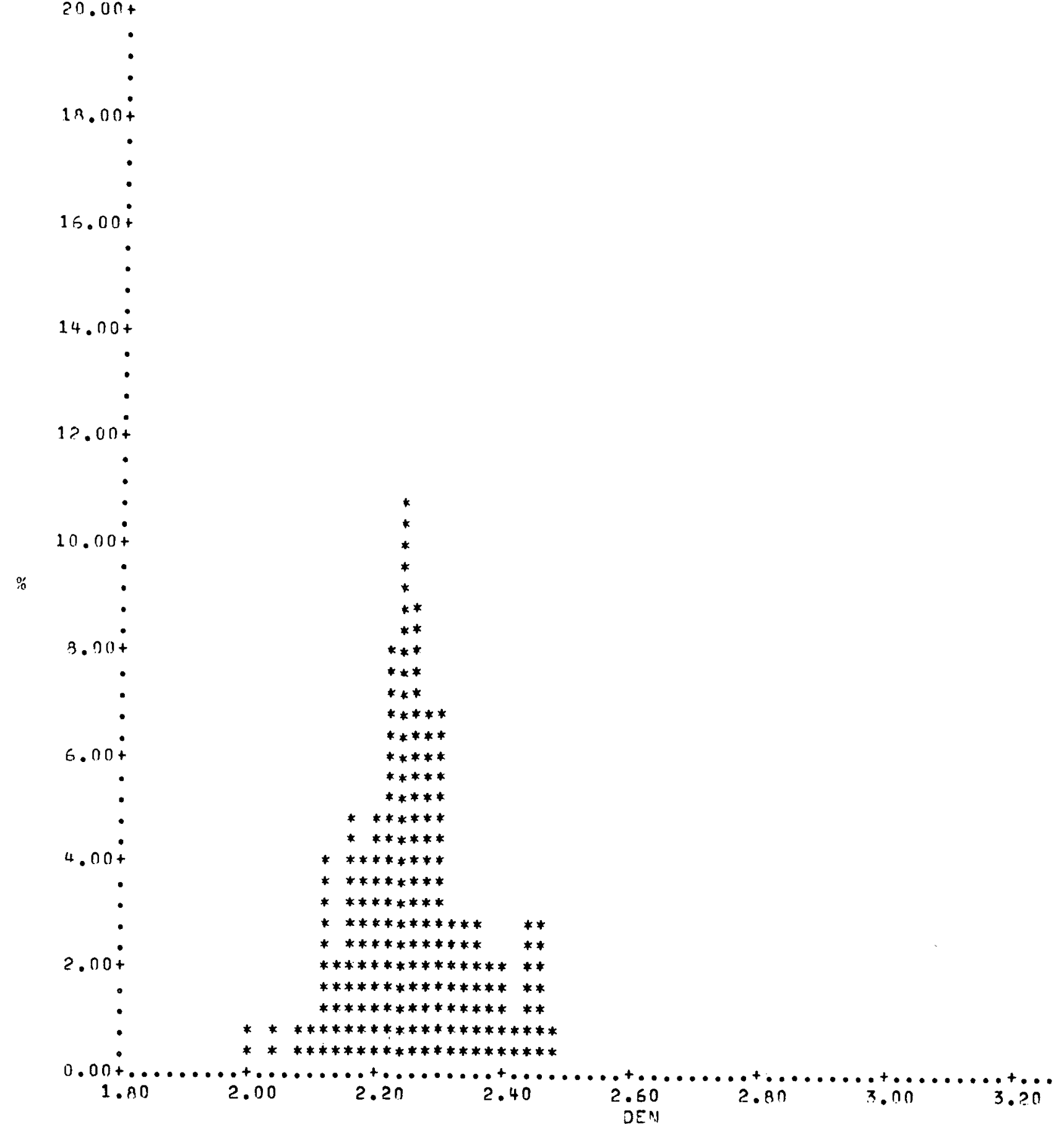

FIGURE 40. Density Histogram 


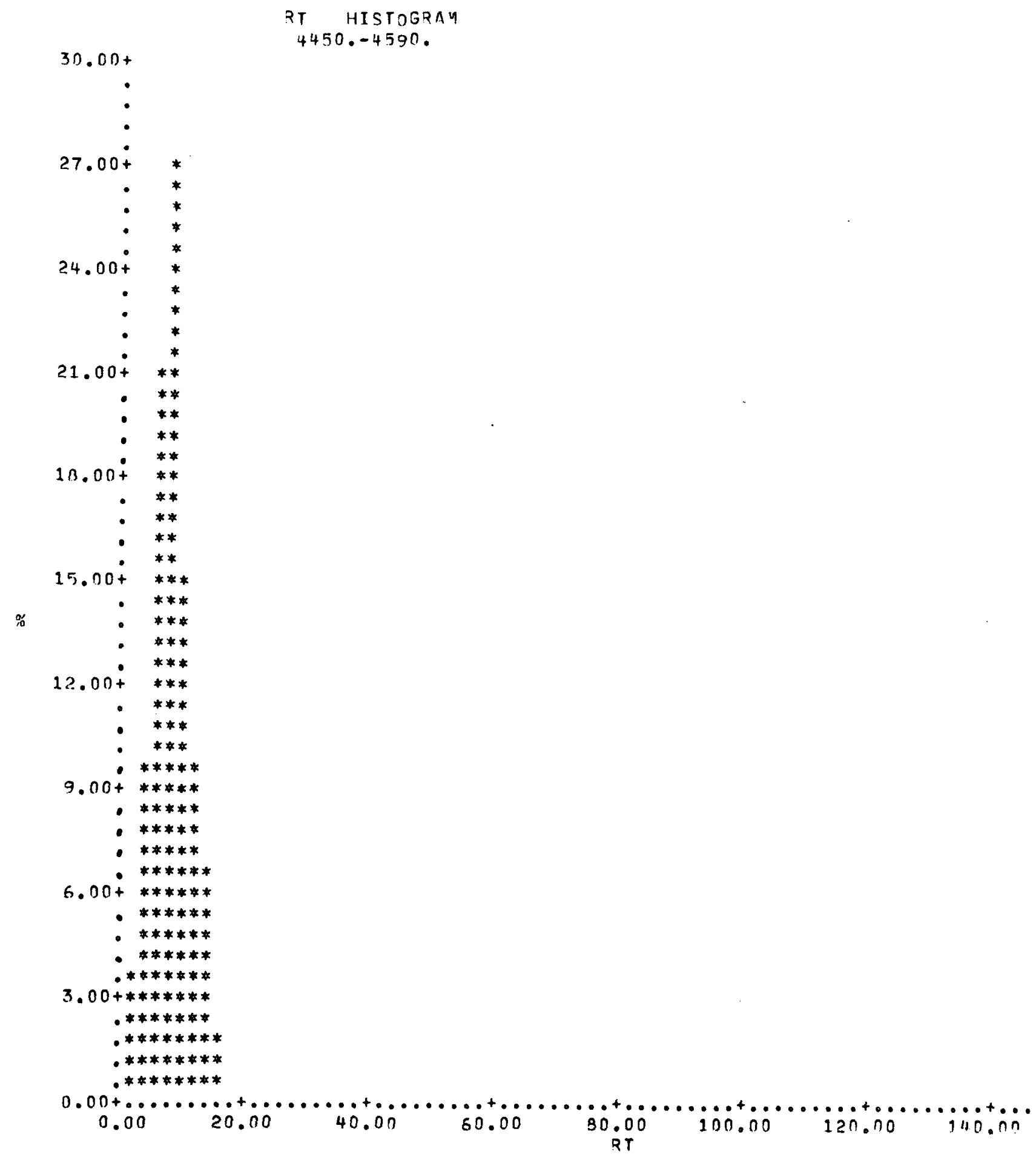

FIGURE 41. Resistivity Histogram 


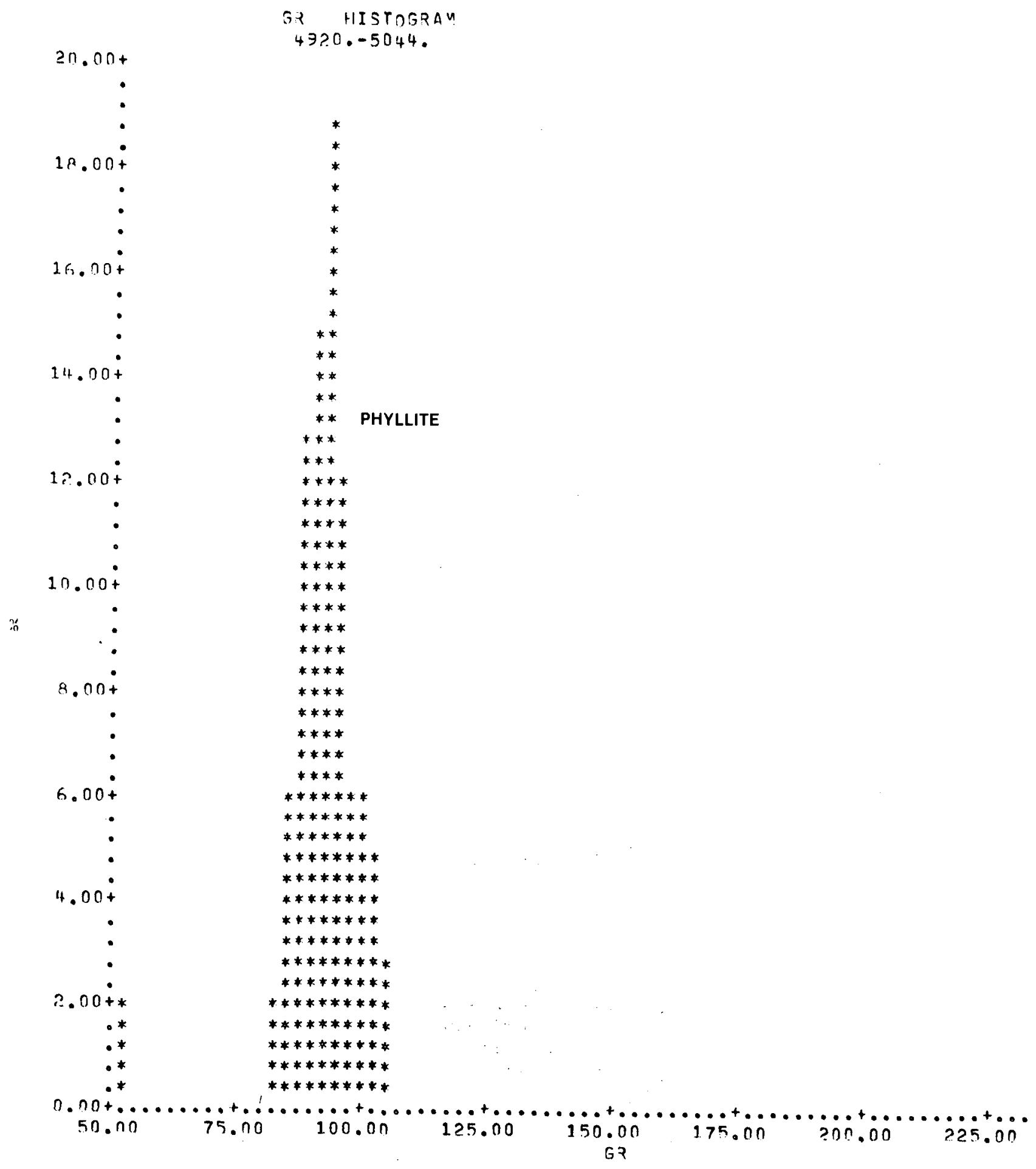

FIGURE 42. Gamma Ray Histogram 


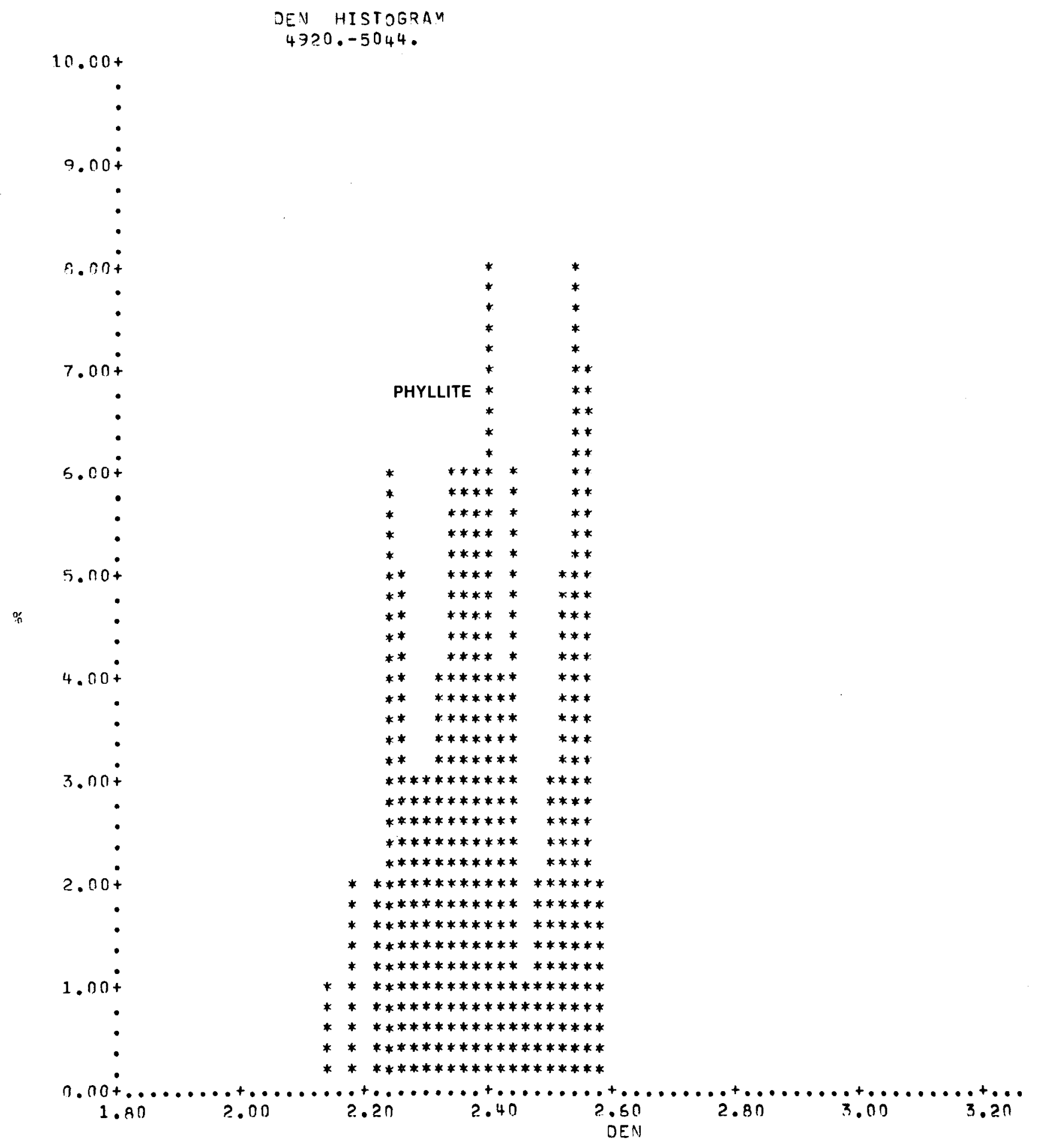

FIGURE 43. Density Histogram 


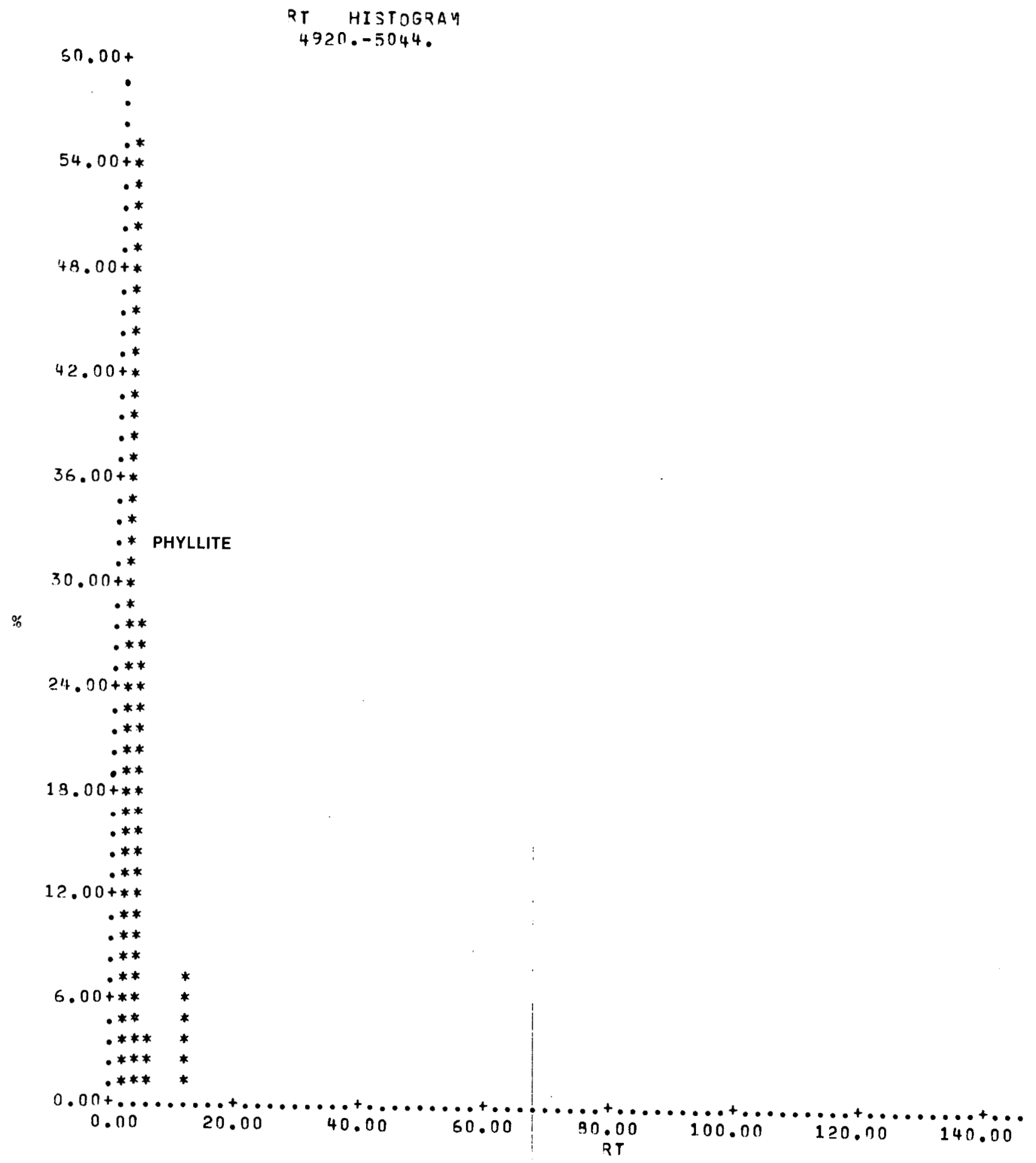

FIGURE 44. Resistivity Histogram 


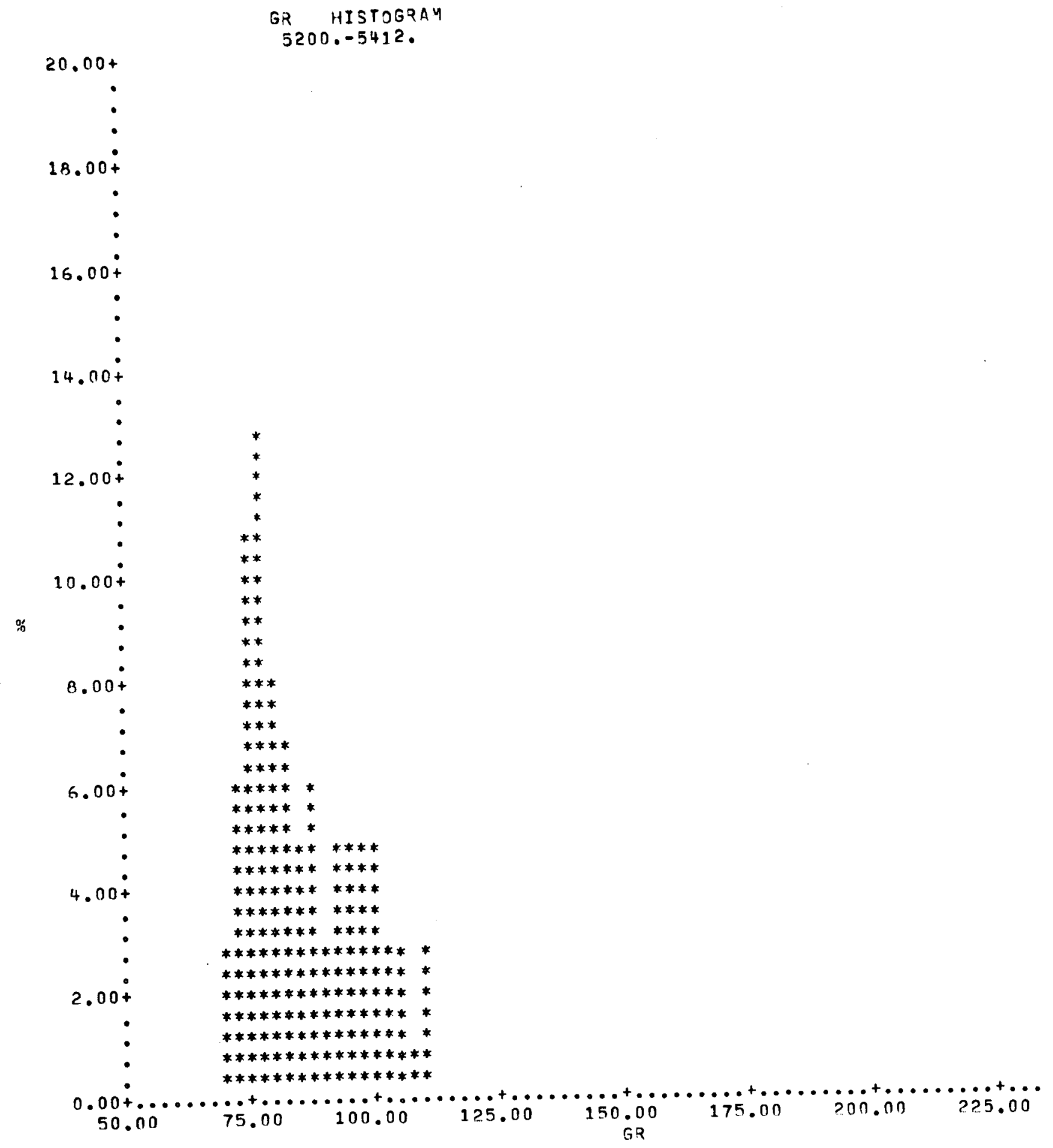

FIGURE 45. Gamma Ray Histogram 


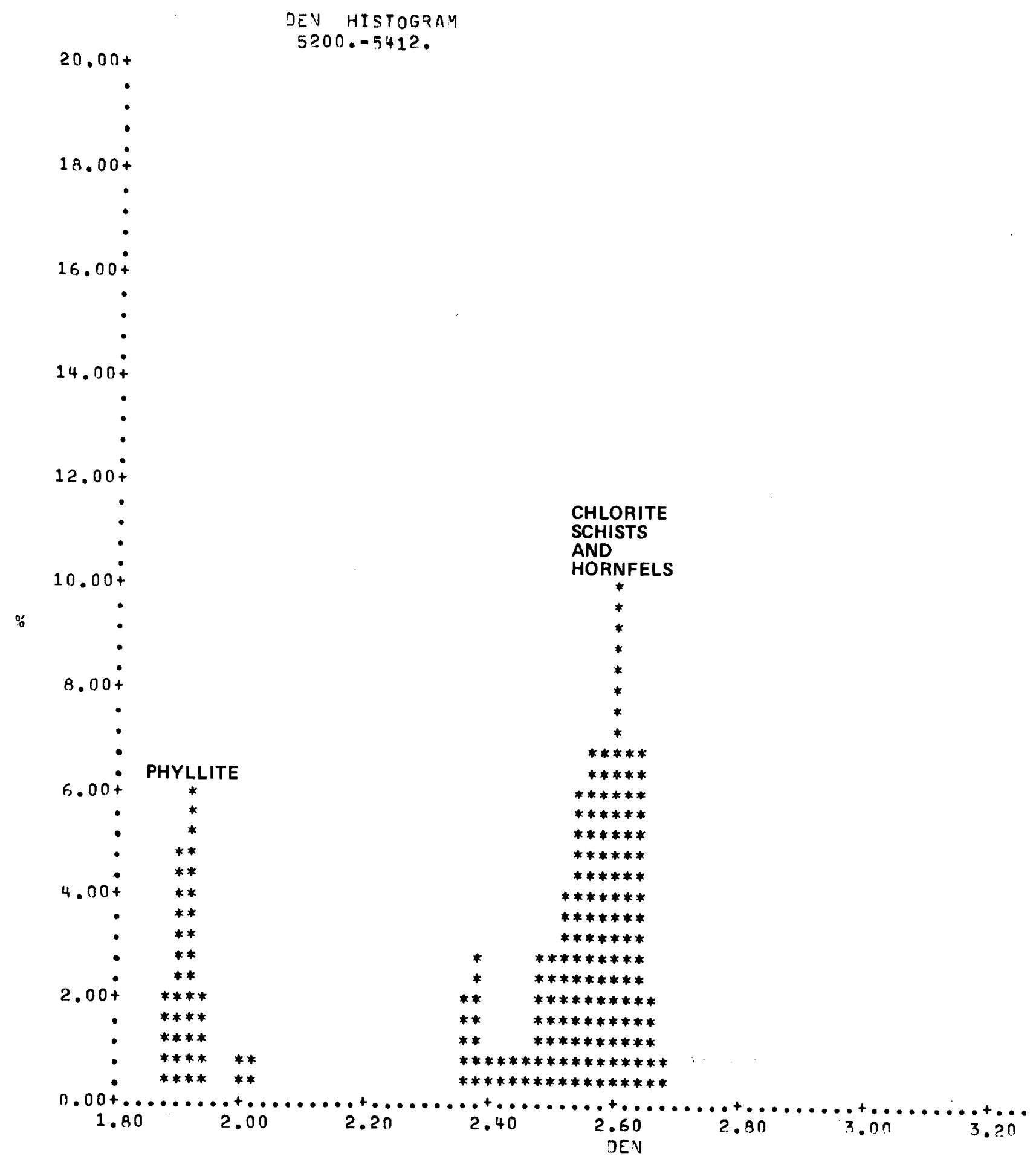

FIGURE 46. Density Histógram 


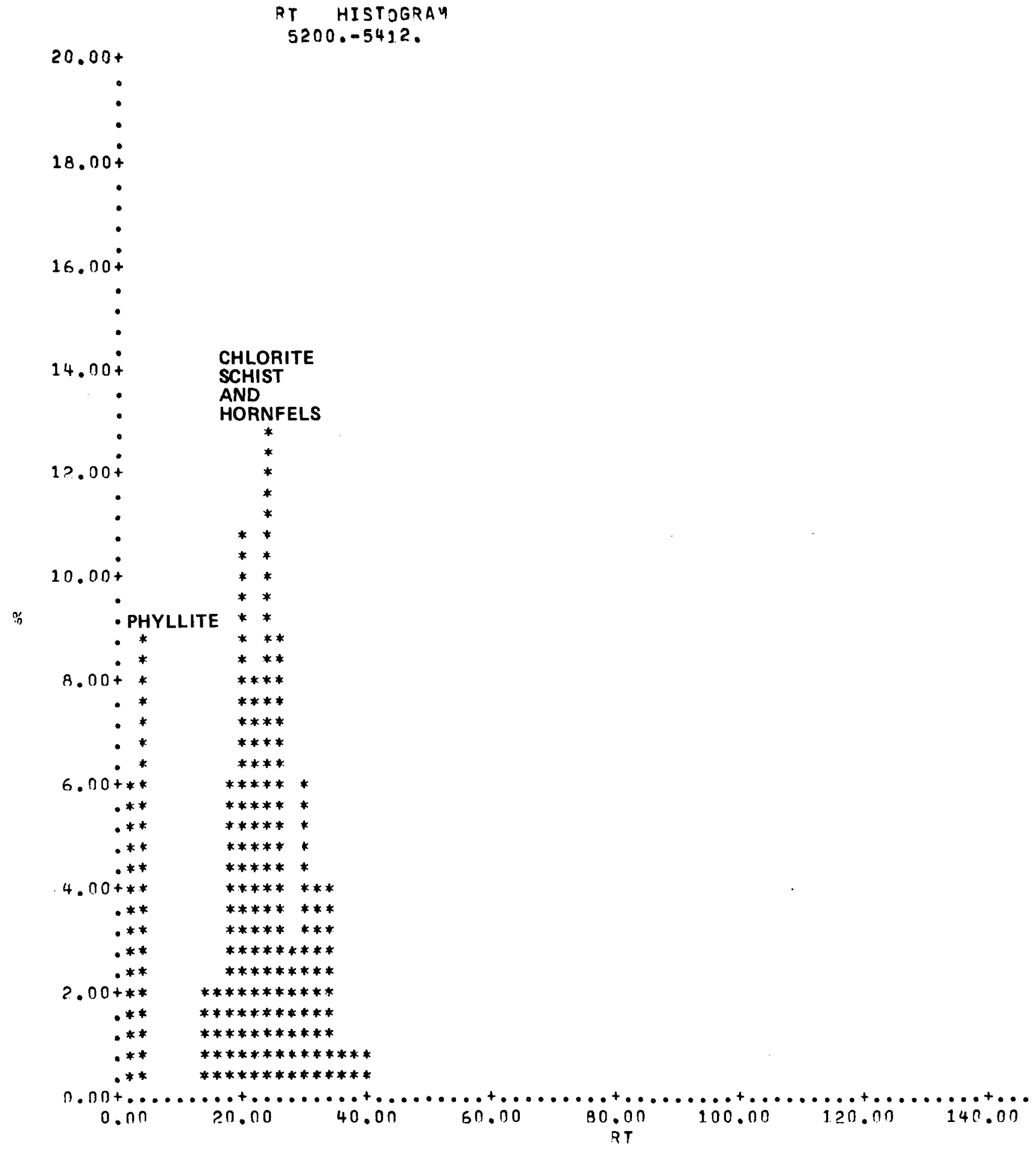

FIGURE 47. Resistivity Histogram 


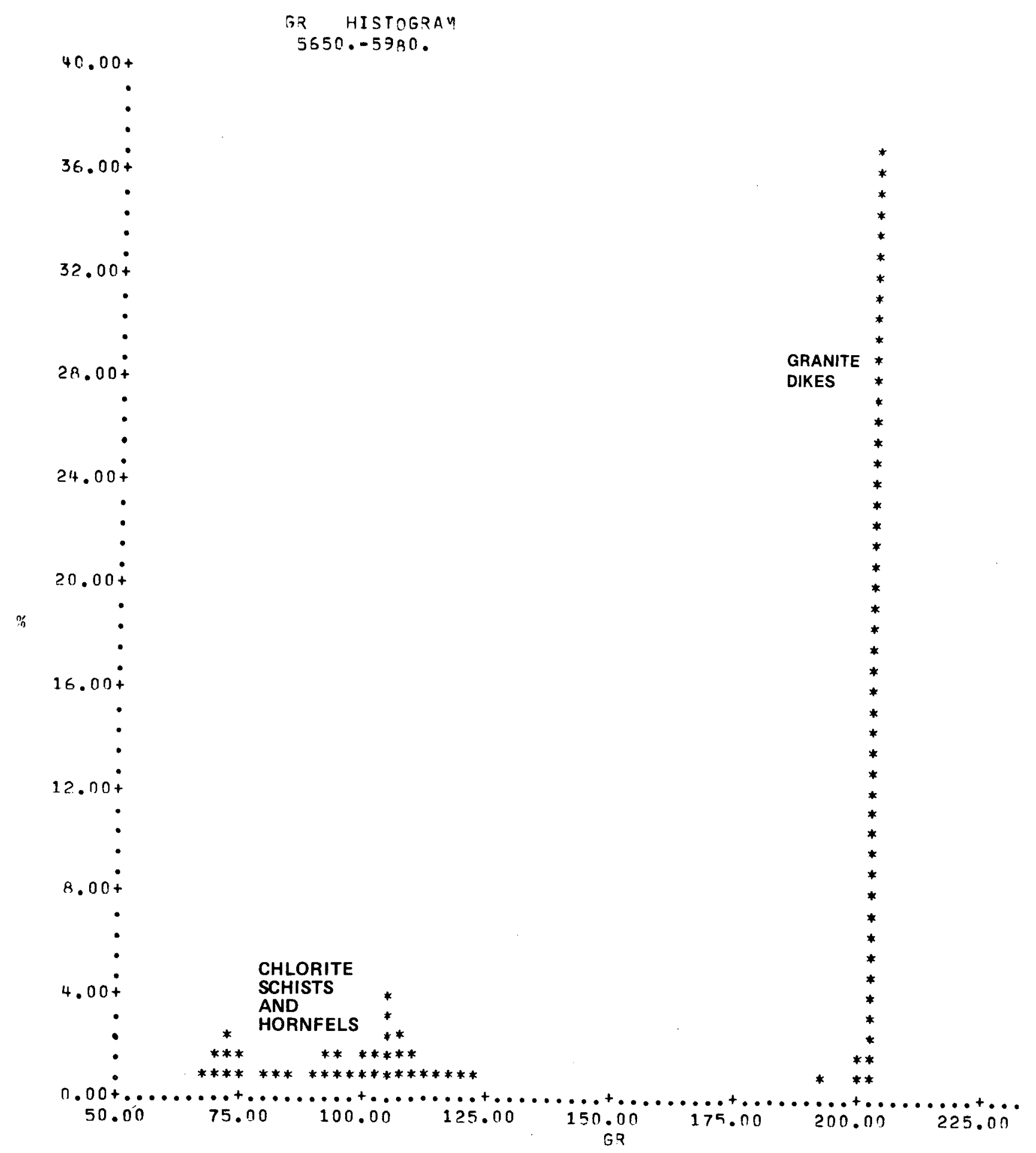

FIGURE 48. Gamma Ray Histogram 


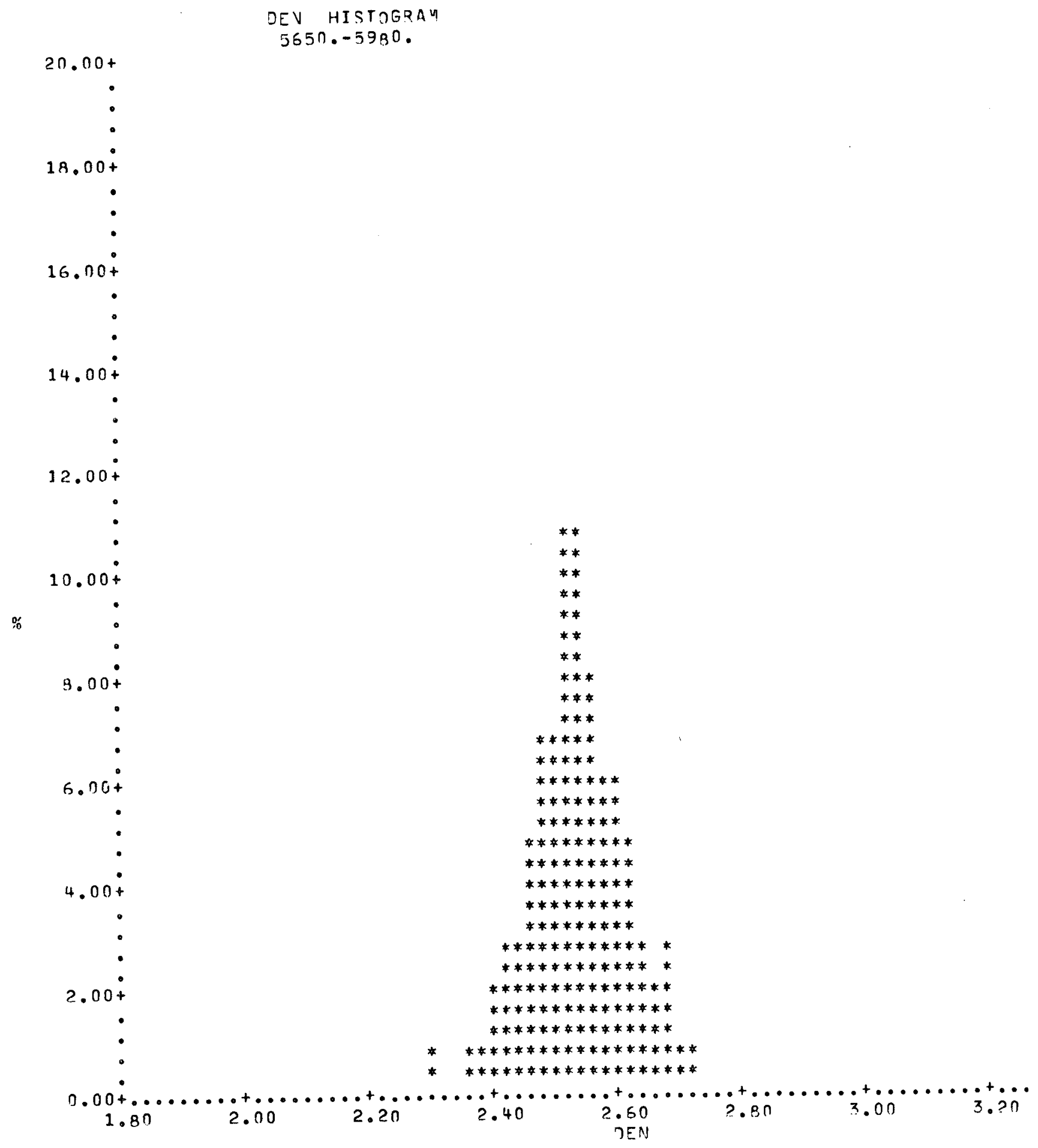

FIGURE 49. Density Histogram 


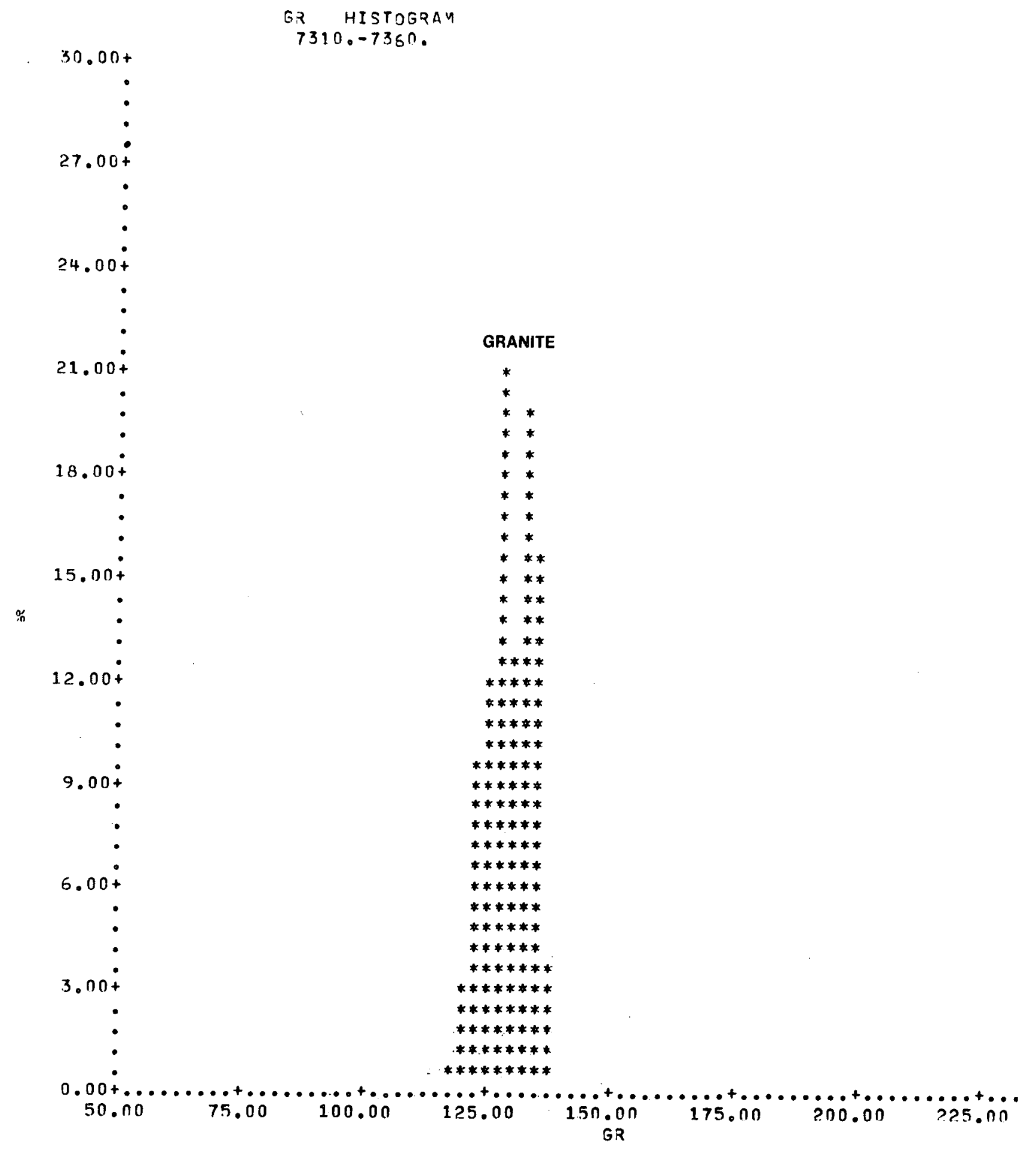

FIGURE 50. Gamma Ray Histogram 


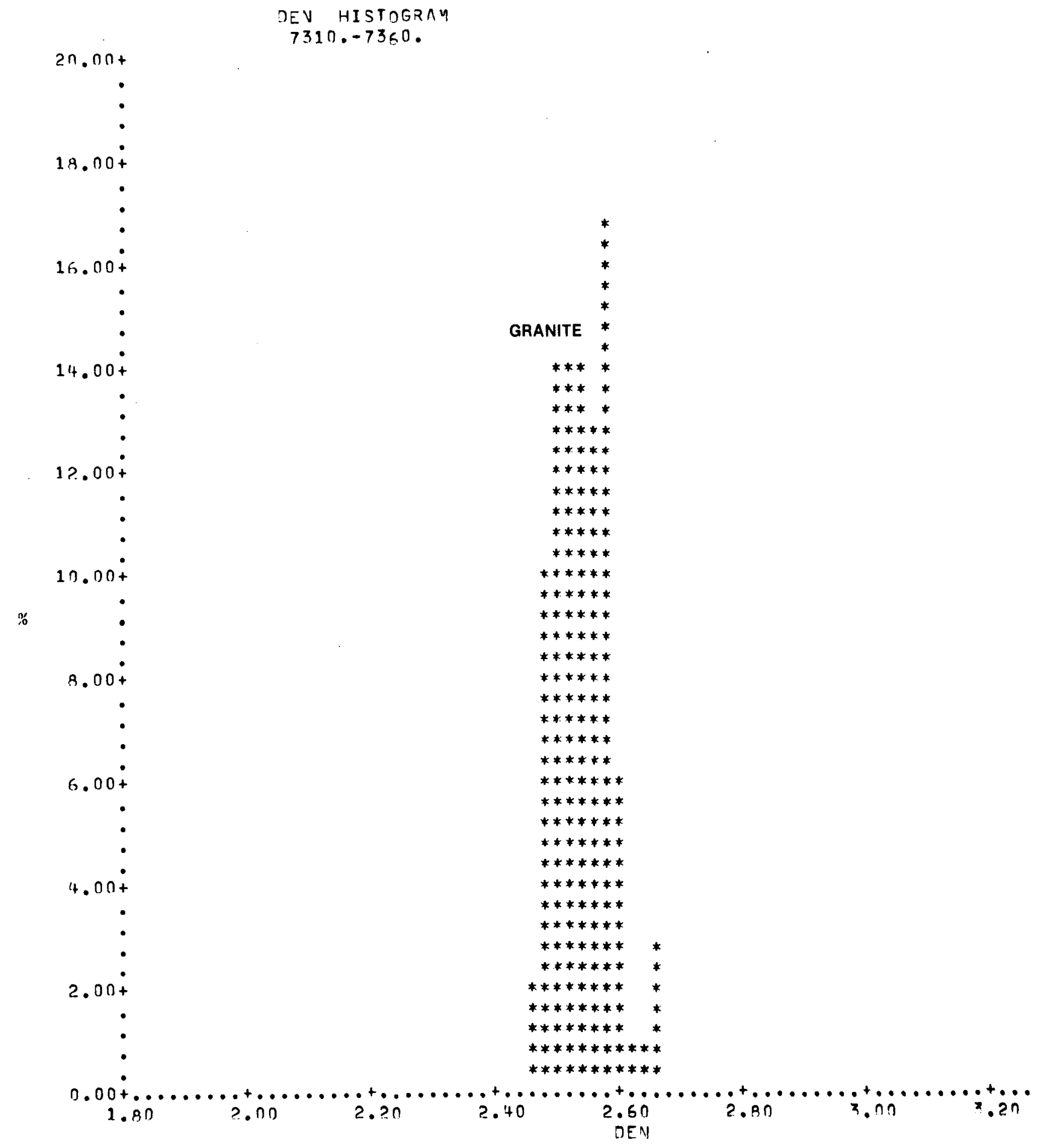

FIGURE 51. Density Histogram 


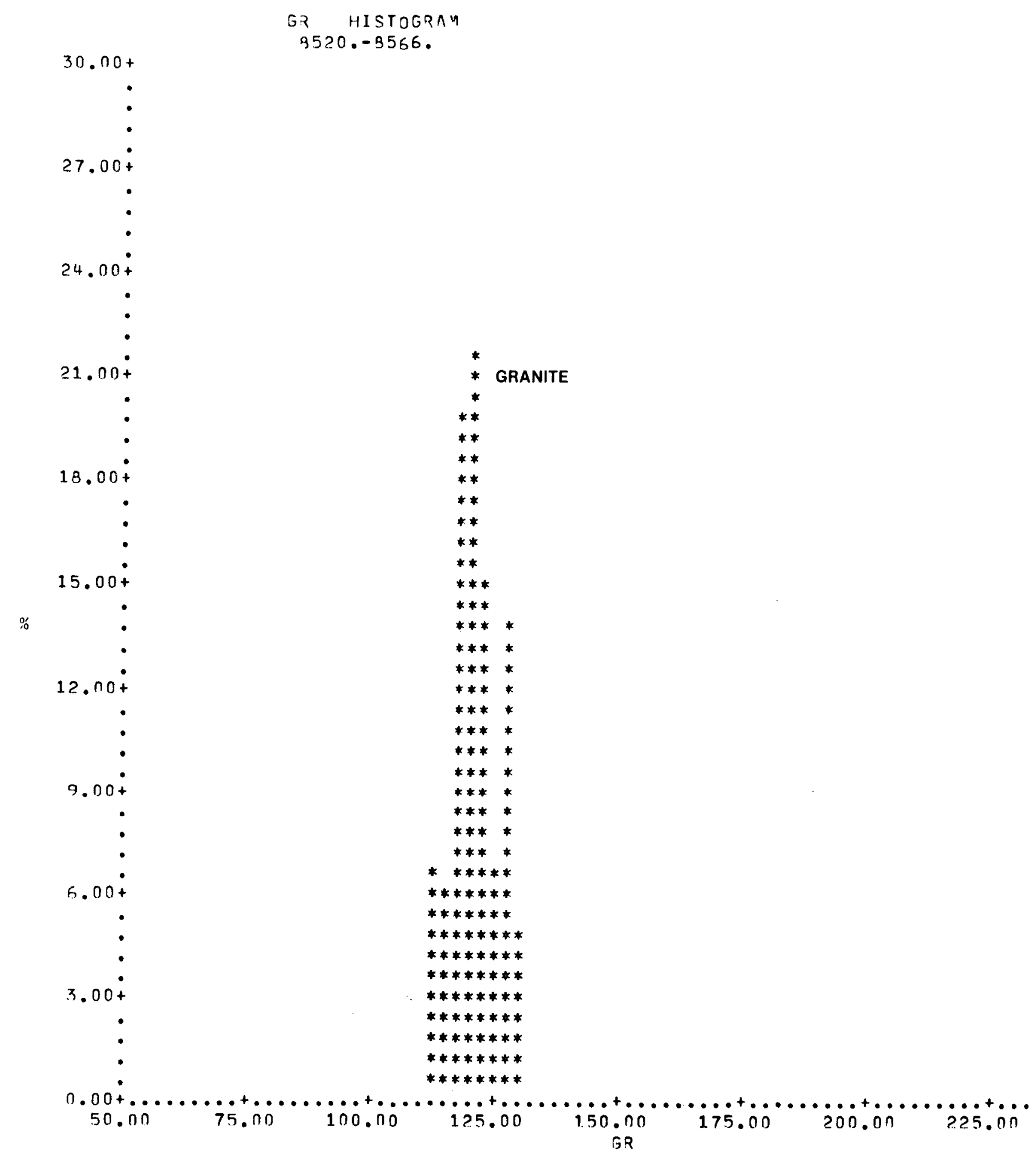

FIGURE 52. Gamma Ray Histogram 


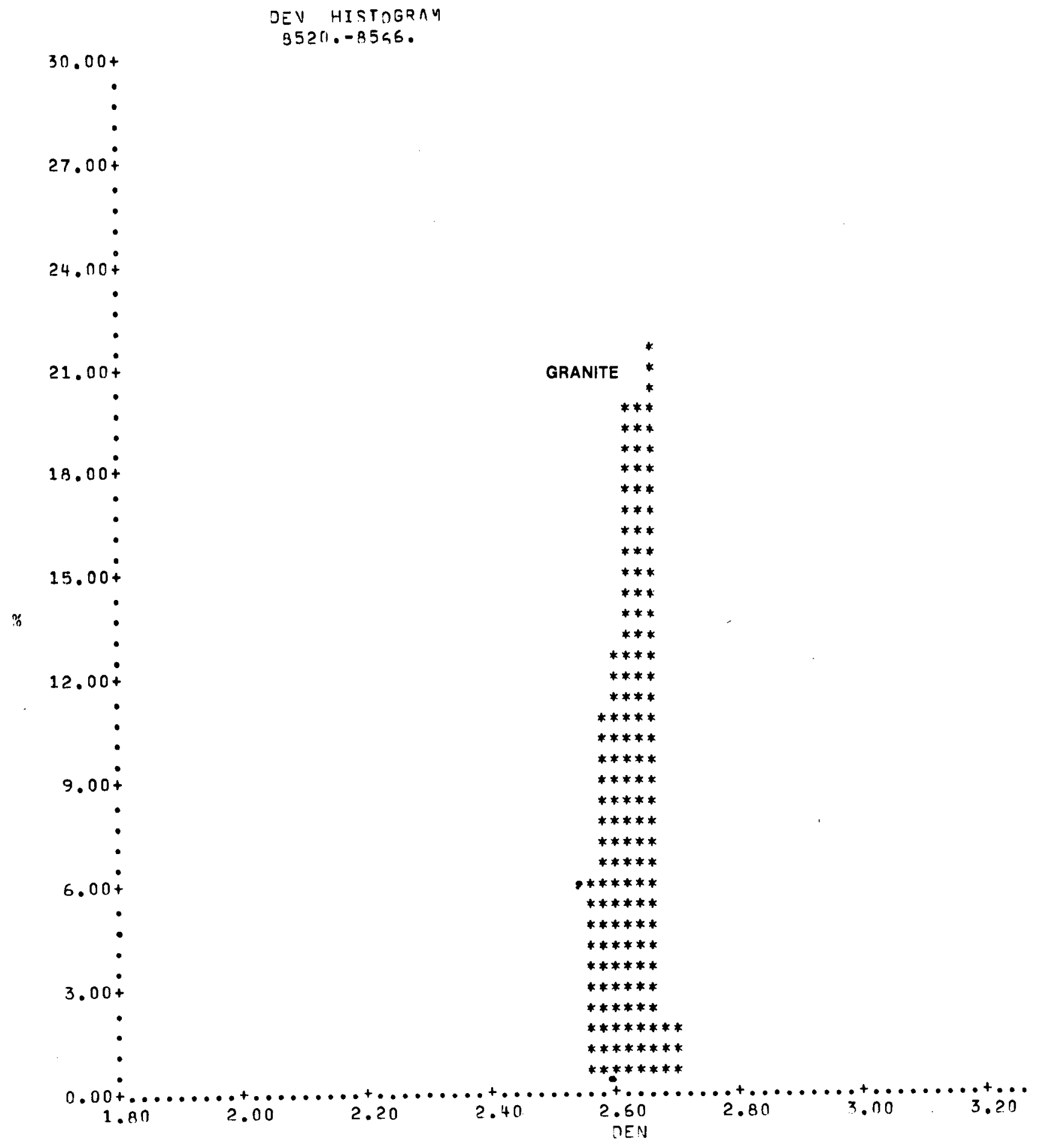

FIGURE 53. Density Histogram 


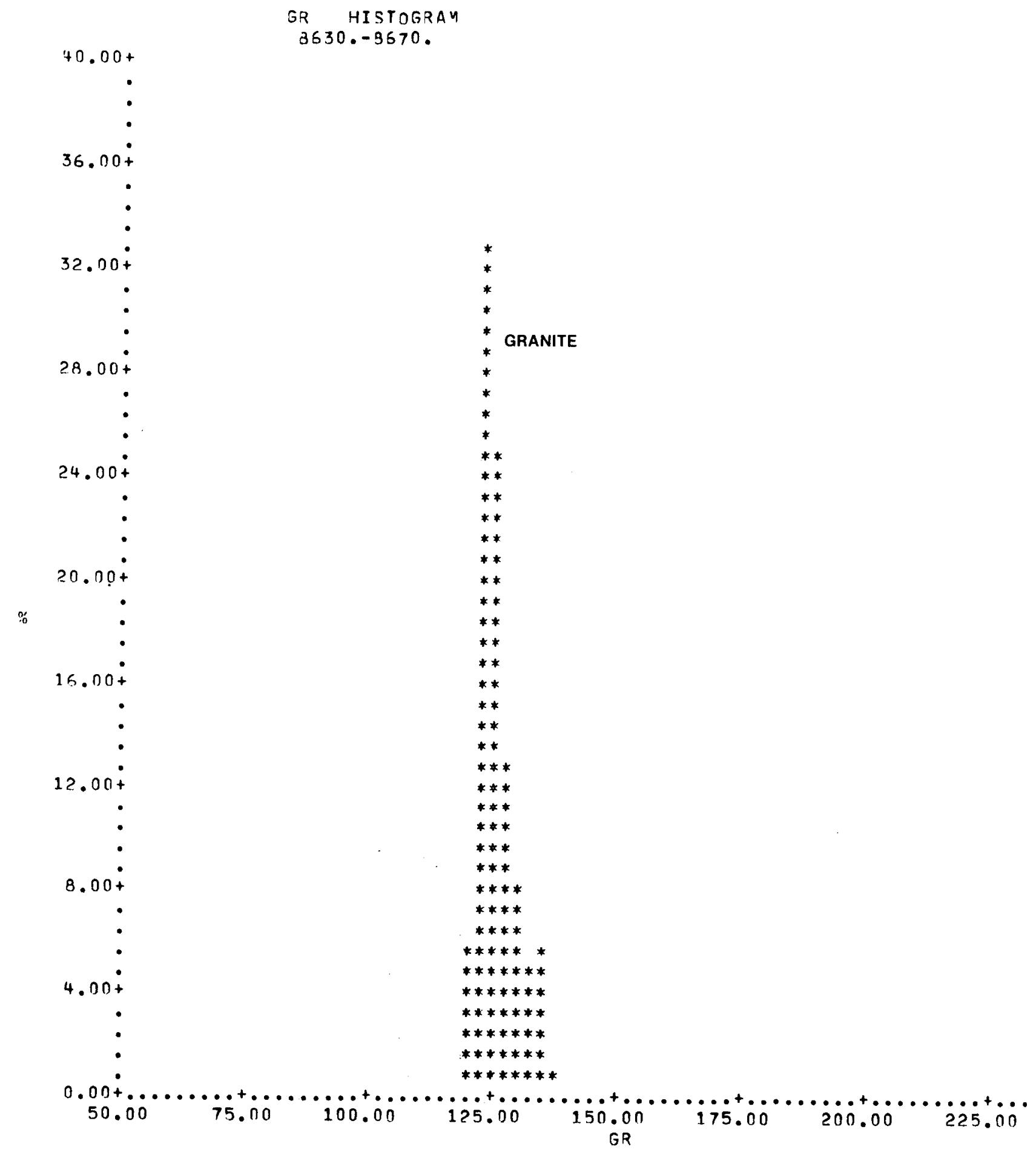

FIGURE 54. Gamma Ray Histogram 


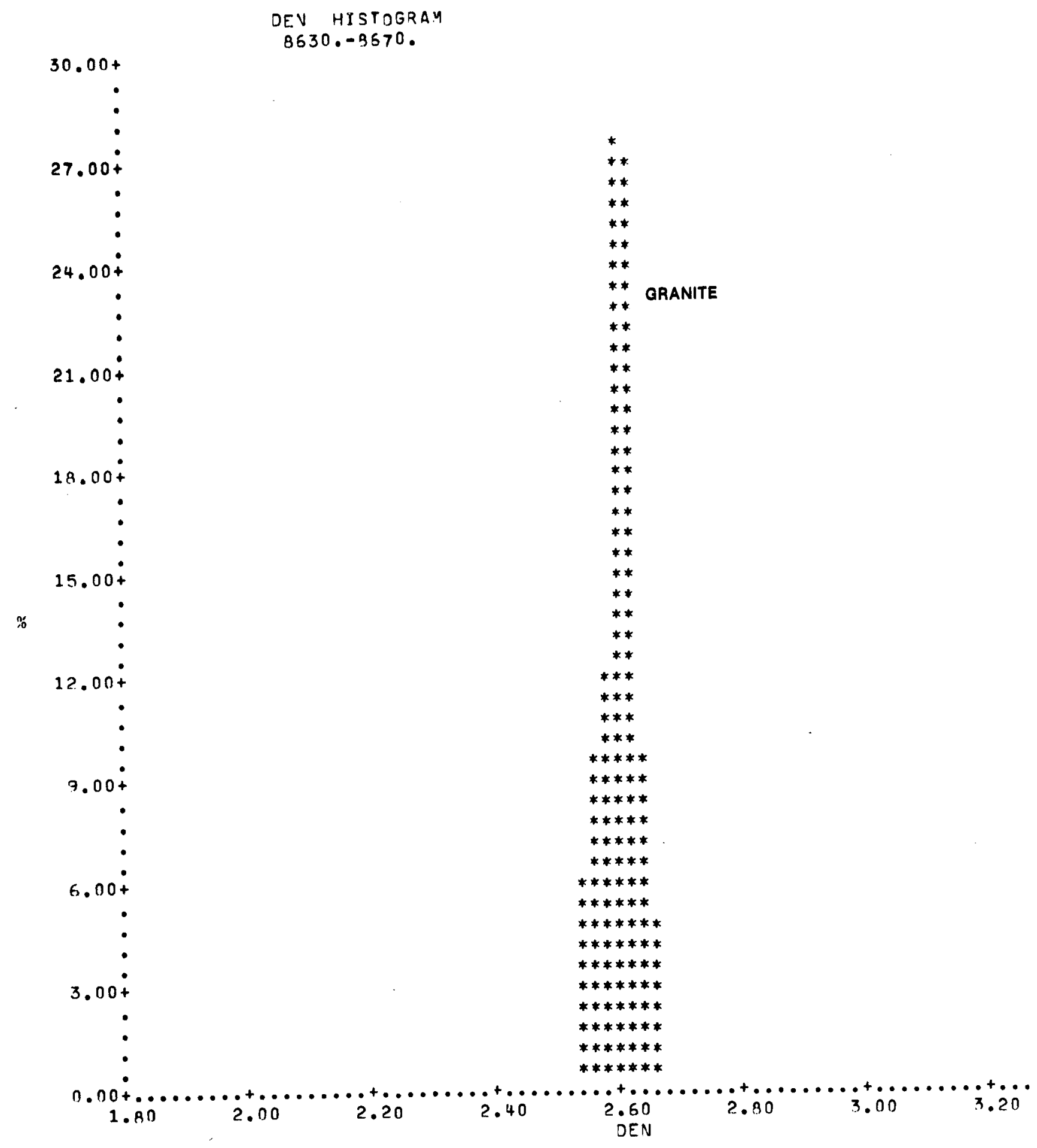

FIGURE 55. Density Histogram 

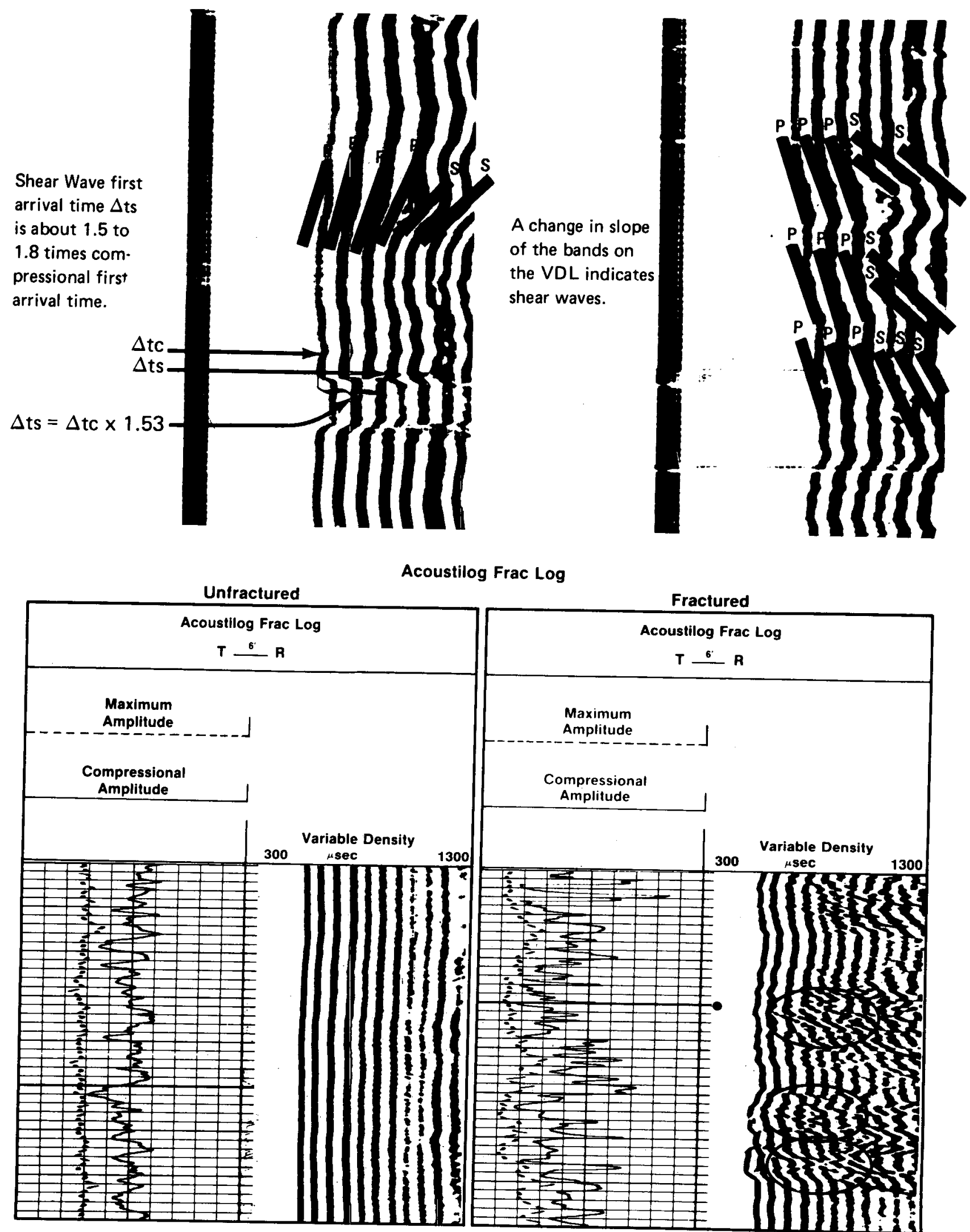

Frac Log

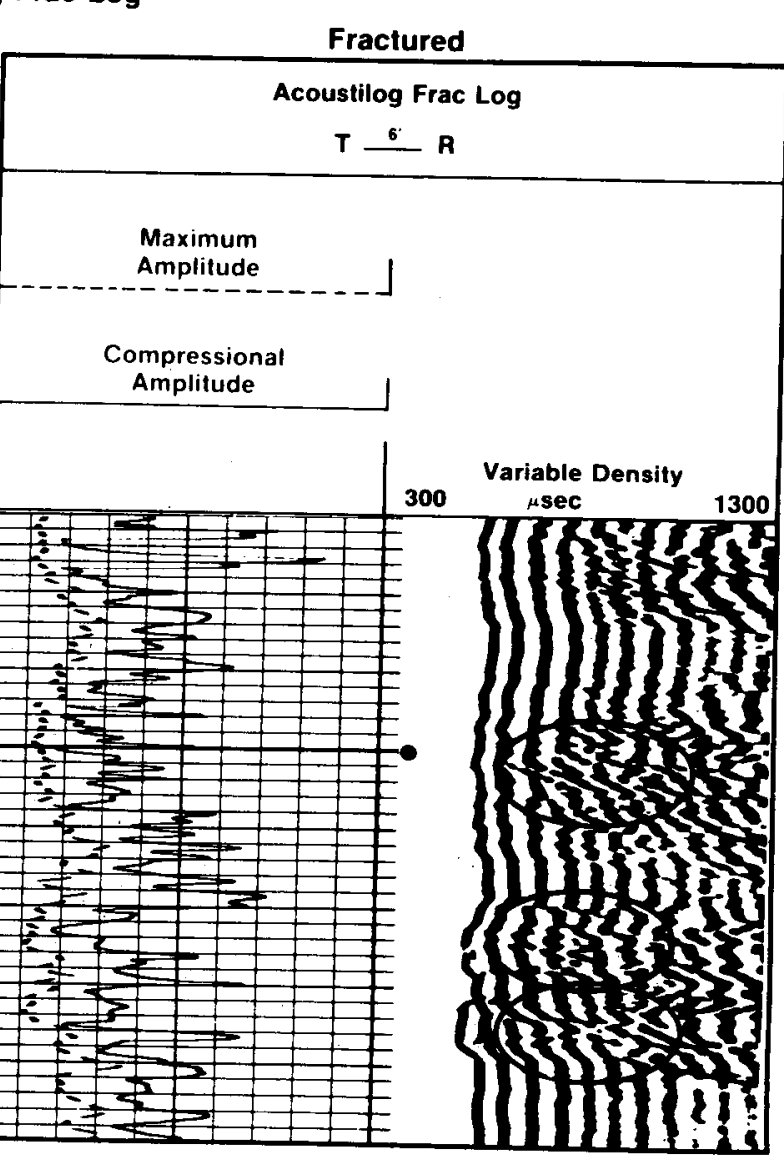

FIGURE 56. Interpretation of Acoustic Fraclog 
$\theta$ 


\section{APPENDIX A - I}

COLLAR ELEVATION $=4595^{\circ}$

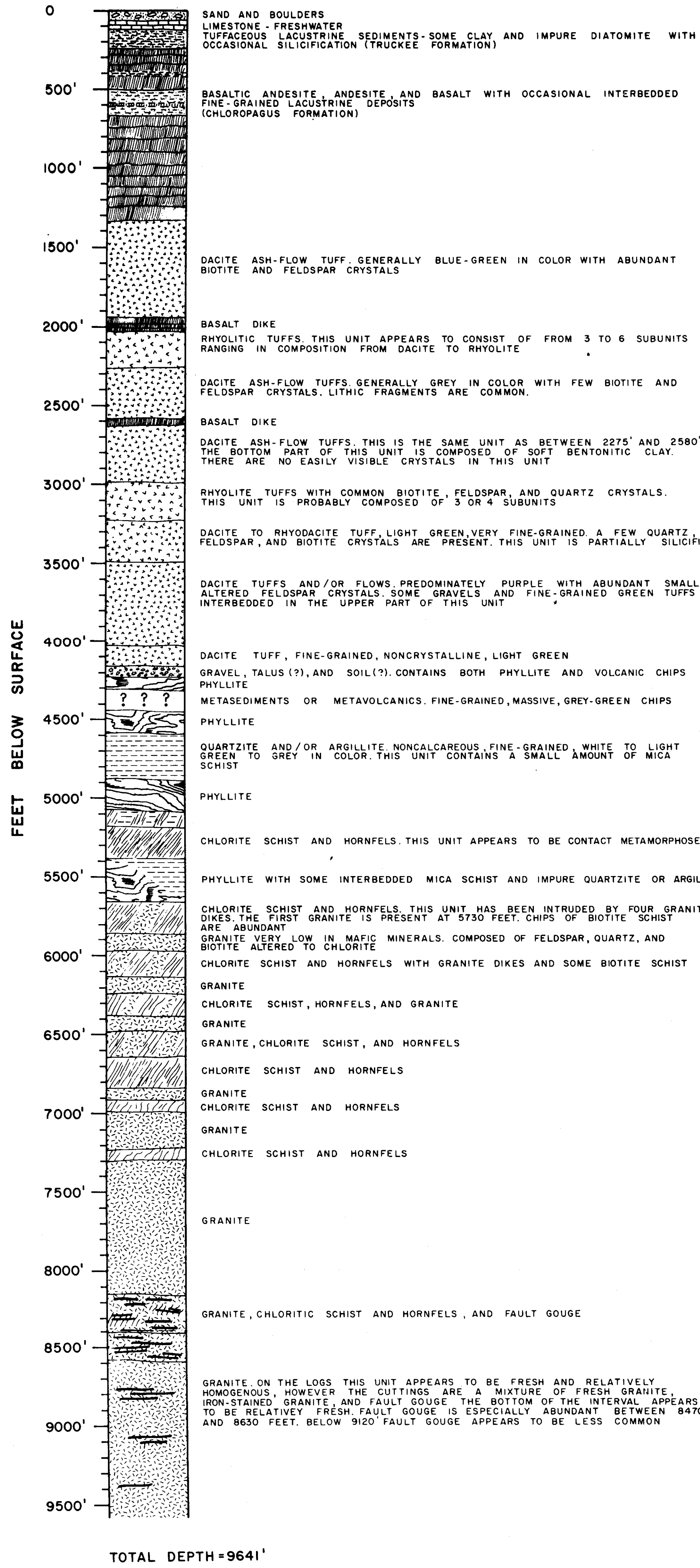

0

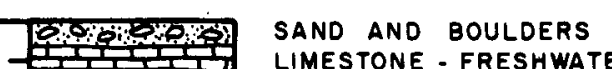

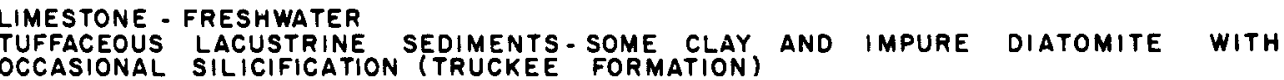

500

$1000^{\prime}$

$1500^{\prime}$

$2000^{\prime}$

$4500^{\prime}$

w

岕

6500

$7000^{\prime}$$$
\text { GRANITE }
$$

CHLORITE SCHIST AND HORNFELS

GRANITE

CHLORITE schist and hornfels

granite

granite, chloritic schist and hornfels, and fault govge

8500

9000

9500' -

TOTAL DEPTH $=9641^{\prime}$

\section{LITHOLOGIC LOG OF DESERT PEAK B 23-I}

(AFTER W. R. BENOIT)

LOCATION = SW NW SECTION 23, T.22N., R.27E.

DATE STARTED $=3-19-79$

DATE COMPLETED $=5-30-79$

PHILLIPS PETROLEUM COMPANY

ENERGY MINERALS DIVISION

RENO, NEVADA 
DRESSER ATLAS

LOGGING SERVICES FOR GEOTHERMAL WELLS

(High-Temperature Equipment)

1. Induction Electrolog ${ }^{\circledR} / \mathrm{SP}$

2. Dual Induction Focused Log

3. Dual Laterolog

4. BHC Acoustilog ${ }^{\circledR}$

5. Compensated Densilog ${ }^{\circledR}$

6. High-Temperature Densilog

7. Compensated Neutron Log

8. Sidewall Epithermal Neutron

9. High-Temperature GR/Neutron Log

10. Caliper/Temperature Log

11. High-Temperature Caliper/Temperature Log

12. Acoustic Fraclog (Variable Density/Signature)

13. Gamma Ray Spectralog

14. Spinner Flowmeter

15. High-Temperature Spinner Flowmeter

16. Fluid Sampler

17. High-Temperature Fluid Sampler
Maximum

Pressure

$172 \mathrm{MPa}$ (25,000 psi)

$172 \mathrm{MPa}$

(25,000 psi)

$138 \mathrm{MPa}$

(20,000 psi)

$138 \mathrm{MPa}$

(20,000 psi)

$138 \mathrm{MPa}$

$(20,000 \mathrm{psi})$

$172 \mathrm{MPa}$

(25,000 psi)

$138 \mathrm{MPa}$

$(20,000$ psi)

$138 \mathrm{MPa}$

$(20,000 \mathrm{psi})$

$172 \mathrm{MPa}$

(25,000 psi)

$138 \mathrm{MPa}$

(20,000 psi)

$138 \mathrm{MPa}$

(20,000 psi)

$138 \mathrm{MPa}$

(20,000 psi)

$138 \mathrm{MPa}$

(20,000 psi)

$117 \mathrm{MPa}$

(17,000 psi)

$117 \mathrm{MPa}$

(17,000 psi)

$138 \mathrm{MPa}$

(20,000 psi)

$138 \mathrm{MPa}$

(20,000 psi)
Maximum

Temperature

$204^{\circ} \mathrm{C}$

$\left(400^{\circ} \mathrm{F}\right)$

$204^{\circ} \mathrm{C}$

$\left(400^{\circ} \mathrm{F}\right)$

$204^{\circ} \mathrm{C}$

$\left(400^{\circ} \mathrm{F}\right)$

$204^{\circ} \mathrm{C}$

$\left(400^{\circ} \mathrm{F}\right.$ )

$204^{\circ} \mathrm{C}$

$\left(400^{\circ} \mathrm{F}\right)$

$260^{\circ} \mathrm{C}$

$\left(500^{\circ} \mathrm{F}\right)$

$204^{\circ} \mathrm{C}$

$\left(400^{\circ} \mathrm{F}\right)$

$204^{\circ} \mathrm{C}$

$\left(400^{\circ} \mathrm{F}\right)$

$260^{\circ} \mathrm{C}$

$\left(500^{\circ} \mathrm{F}\right)$

$204^{\circ} \mathrm{C}$

$\left(400^{\circ} \mathrm{F}\right)$

$288^{\circ} \mathrm{C}$

$\left(550^{\circ} \mathrm{F}\right)$

$204^{\circ} \mathrm{C}$

$\left(400^{\circ} \mathrm{F}\right)$

$204^{\circ} \mathrm{C}$

$\left(400^{\circ} \mathrm{F}\right)$

$204^{\circ} \mathrm{C}$

$\left(400^{\circ} \mathrm{F}\right)$

$260^{\circ} \mathrm{C}$

$\left(500^{\circ} \mathrm{F}\right)$

$204^{\circ} \mathrm{C}$

$\left(400^{\circ} \mathrm{F}\right)$

$288^{\circ} \mathrm{C}$

$\left(550^{\circ} \mathrm{F}\right)$ 
Appendixes A-III through A-VI are on microfiche in pocket on inside back cover. 